\title{
Status of the DOE Battery and Electrochemical Technology Program V
}
R. Roberts
Roberts Consultants, Inc.
Chevy Chase, Maryland

June 1985

Prepared by Roberts Consultants, Inc.

for Pacific Northwest Laboratory

under Contract DE-AC06-76RLO 1830

with the U.S. Department of Energy

Pacific Northwest Laboratory

Operated for the U.S. Department of Energy

by Battelle Memorial Institute 


\title{
DISCLAIMER
}

This report was prepared as an account of work sponsored by an agency of the United States Government. Neither the United States Government nor any agency thereof, nor any of their employees, makes any warranty, express or implied, or assumes any legal liability or responsibility for the accuracy, completeness, or usefulness of any information, apparatus, product, or process disclosed, or represents that its use would not infringe privately owned rights. Reference herein to any specific commercial product, process, or service by trade name, trademark, manufacturer, or otherwise, does not necessarily constitute or imply its endorsement, recommendation, or favoring by the United States Government or any agency thereof. The views and opinions of authors expressed herein do not necessarily state or reflect those of the United States Government or any agency thereof.

\author{
PACIFIC NORTHWEST LABORATORY \\ operated by \\ BATTELLE \\ for the \\ UNITED STATES DEPARTMENT OF ENERGY \\ under Contract DE-AC06-76RLO 1830
}

\begin{tabular}{|c|c|}
\hline \multirow{2}{*}{\multicolumn{2}{|c|}{ Printed in the United States of America }} \\
\hline & \\
\hline \multicolumn{2}{|c|}{$\begin{array}{l}\text { Available from } \\
\text { onal Technical Information Service }\end{array}$} \\
\hline \multicolumn{2}{|c|}{ United States Depanment of Commerce } \\
\hline \multirow{2}{*}{\multicolumn{2}{|c|}{$\begin{array}{l}5285 \text { Port Royal Road } \\
\text { Springfield, Virginia } 22161\end{array}$}} \\
\hline & \\
\hline \multirow{2}{*}{\multicolumn{2}{|c|}{$\begin{array}{l}\text { NIIS Price Codes } \\
\text { Microfiche A01 }\end{array}$}} \\
\hline & \\
\hline \multicolumn{2}{|c|}{ Printed Copy } \\
\hline & Price \\
\hline Pages & Codes \\
\hline 007-025 & $A 02$ \\
\hline 026-050 & $\mathrm{A} 03$ \\
\hline 051-075 & A04 \\
\hline $076-100$ & A05 \\
\hline $101-125$ & A06 \\
\hline $126-150$ & A07 \\
\hline 151.175 & A08 \\
\hline $176-200$ & A09 \\
\hline 201.225 & A010 \\
\hline $226-250$ & A011 \\
\hline $251-275$ & A012 \\
\hline $276-300$ & A013 \\
\hline
\end{tabular}


STATUS OF THE DOF BATTERY AND

ELECTROCHEMICAL TECHNOLOGY

PROGRAM V

\author{
R. Roberts \\ Roberts Consultants, Inc. \\ Chevy Chase, Maryland
}

June 1985

Prepared by Roberts Consultants, Inc. for Pacific Northwest Laboratory under Contract DE-AC06-76RL0 1830 with the U.S. Department of Energy under Agreement B-L4300-A-V

Pacific Northwest Laboratory

Richland, Washington 99352 
The author wishes to express his apprectation to the participants at the Sixth DOE Electrochemical Contractor's Review (June 1984) for their cooperation in furntshing supplemental information and reviewing the technical content of the report. The continuing encouragement, advice, and assistance of the contract monitors: Carl H. Imhoff, Pactfic Northwest Laboratory, and Jonathan Hurwitch, Battelle-Columbus Laboratories; and of Albert $R$. Landgrebe of DOE have been of great value.

Special thanks go to Susle Armstrong for her assistance in the preparation of the report, and D.M. Rutherford of Pacific Northwest Laboratory for his able handling of contractual arrangements.

This work was supported by the Assistant Secretary for Conservation and Renewable Energy, Office of Energy Systems Research, Division of Energy Storage of the U.S. Department of Energy under Contract No. DE-AC06-76RLO 1830 through Subcontract B-L4300-A-V. 
This report reviews the status of the Department of Rnergy

(DOE) Electrochemical Energy Storage Branch (ECS) Progran as of June 1984. Actlvities of related programs investlgating the applicabillty of batterles and fuel cells in transportation, stationary energy storage, and solar energy systems are sumarized.

The ECS program consists of two activitles, Technology Base Research (TBR) managed by the Lawrence Berkeley Laboratory (LBL) and Exploratory Technology Development and Testing (ETD) managed by the Sandia National Laboratories (SNL).

The status of the Battery Energy Storage Test (BEST) Facility is presented, including the status of the batterles to be tested. ECS program contributions to the advancement of the lead-acid battery and specific examples of technology transfer from this program are given.

The advances during the perlod December, 1982 to June, 1984 in the characterization and performance of the lead-acid, Iron/ntckel-oxide, 1ron/a1r, aluminum/a1r, zlnc/bromine, zinc/ferricyanlde, and sodium/sulfur batterles and in fuel cells for transport are summarized. Novel technlques and the application of established techniques to the study of electrode processes, especially the electrode/electrolyte interface, are described.

Research wth the potential of leading to 1mproved ceramic electrolytes and positive electrode contalner and current-collectors for the sodium/sulfur battery is preaented. Advances in the electrocatalysis of the oxygen (a1r) electrode and the relationship of these advances to the Iron/air and aluminum/a1r batteries and to the fuel cell are noted. The quest for new battery couples and battery materials 18 reviewed.

New developments in the modeling of electrochemlcal cell and electrode performance with the approaches to test these models are reported. Of spectal note is the application of microelectronic technology to the preparation of a mosa1c microelectrode for the study of gas bubble formation and the associated mass transport at an operating electrode. 

EXECUTIVE SUMMARY

The S1xth Department of Energy (DOE) Electrochemica1 Contractor's Review, June 25-29, 1984, covered past accomplishments, continuing improvements in battery and electrochemical system performance, and related basic and applied research. These activities form the scientifia and technological base for exploring alternative solutions and new approaches to energy conservation through advanced electrochemical technologies. Selected highlights from recent research are summarized below.

The past accomplishments resulting in technology transfer to industry or to mission-oriented federal agencies, such as the Department of Defense, were noted in the program of the Electrochemical Energy Storage (ECS) Branch. These accomplishments included:

- Gould, Inc.'s development of a maintenance-free, 6 volt, 100 ampere hour lead-acid battery for use in solar energy systems.

- Dianond Shamrock Corporation's and Case Western Reserve University's development of a platinum-based air electrode now being funded and evaluated by ELTECH Systems, Inc. for reducing energy in the chlor-alkali process.

- The Prototech-developed hydrogen electrode, which is being evaluated by EXXON for energy savings in zinc recovery.

- The initiation by the U.S. Air Force of the development of the Ford sodium/sulfur battery for satellite applications.

- The completion of negotiations between SOHIO and the National Aeronautics and Space Administration for continuIng the development of the Redox battery.

In aldition to Gould's development, several other advances in leadrac1d battery technology are being used or evaluated by industry.

Sandia National Laboratories (SNL), under it Exploratory Technology Development and Testing (ETD) activities, is continuing its testing of batteries for solar energy systems and other stationary battery applications. SNL is also coordinating the activities of the Electric Vehicle Battery Testing Task Force.

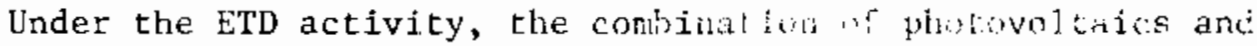
battery storage has been shown to meet the dally variations in loat demands for residential power at the Jacarilla Indian Reservatiun. lihe 
Electric Vehicle Battery Task Force has reviewed and modified the electric vehicle battery test procedures.

The operation of the Battery Energy Storage Test (BEST) Facility by the Public Service Gas and Electric Co. has demonstratcd the compatabillty of lead-acid battery energy storage with the operation of an electric utility. The testing of a $500 \mathrm{kWh}$ zinc/chlorine battery, developed by Energy Development Associates with partial DOE support, had been Inftiated at the BEST Facility and had completed baseline cycle tests in Apri1, 1984.

The ETD activity is emphasizing the development of the zinc/bromine and the sodium/sulfur batteries. Improvements in the performance of the zinc/bromine battery are continuing and lower cost processing technology has been developed. A $20 \mathrm{kWh}, 120 \mathrm{~V}$ battery has been built and is being tested. This battery is to be evaluated by SNL for energy storage in a photovoltaic system. Earlier design studies of an $80 \mathrm{kWh}$ zinc/bromine battery for stationary energy storage in utilities and of a 10-100 kWh battery for electric vehicles projected the cost for the large-scale production of this battery to be $\$ 28 / \mathrm{kW}(1980 \$)$.

The sodium/sulfur battery investigations emphasize solutions to the problems of early cell failures and the corrosion of the positive container and current collector. Three modules of a stationary energy storage battery, a total of 384 cells, underwent a 32-month test. A statistical analysis of the cell performance indicated a characteristic life for these cells of approximately 1500 days.

The effort to develop a low-cost corrosion-resistant positive current collector and container for the sodium/sulfur battery has been increased. Doped chromium oxide and lanthanum chromite have been shown to be corrosion-resistant under battery operating conditions. Fabrication of coatings made from these materials is to be attempted. It has also been observed that composites of aluminum with silicon carbide have good corroston-resistance while retaining satisfactory conductivity.

The toughening of the beta-alumina electrolyte with zirconia has been demonstrated. Th1s approach is expected to improve the lifetime of the ceramic electrolyte used in the sodium/sulfur battery.

The Technology Base Research activity includes applied research on battery couples, and fundamental studies on electrode phenomena and electrochemical engineering.

The major battery system being studied is the aluminum/air cell. This is a mechanically rechargeable system in which aluminum negative plates are mechanically replaced, the aluminum hydroxlde formed removed, and water added. Research is continuing on improved alloys for the 
negative electrode, the collection process for the aluminum hydroxide produced, and catalysts for the air electrode. Heat-treated cobalt macrocyclics have given improved air-electrode performance with a lower rate of carbon substrate corrosion than platinum catalyzed electrodes. The improved catalysis of the air electrode has a1so impacted on the iron/air and fuel-cell technologies.

To advance electrocatalysis, improved and new techniques for studying electrode surfaces, especially in-situ measurements, have been developed. One approach is surface-enhanced Raman spectroscopy. Another is high-resolution electron energy loss spectra being used at Brookhaven National Laboratory. An in-situ electron scattering technique is being developed at Los Alamos National Laboratory for studying the electrode-electrolyte interface.

Studies of alternative electrolytes for the zinc/nickel-oxide battery with lower zincate ion or zinc hydroxide solubility and pulsed charging indicate enhanced reversibility of the zinc electrode.

The studies of the engineering principles for electrochemical cells have given improved cell and electrode modeling capabilities. These have been applied to flow-through and flow-by porous electrodes, fluidized- and falling-bed electrodes, and descriptions of mass and heat transfer. A novel technique, based on microelectronics, has been developed and applied to the study of gas evolution at electrodes.

The completed electrochemical process investigations included electro-organic synthesis. The study of the simultaneous oxtdation and reduction of glucose to two useful products, gluconic acid and sorbitol, has shown that this is a more economic approach than producing the same products in separate cells. 


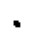


TABLE OF CONTENTS

Page

LIST OF TABLES

$\mathbf{x}$

LIST OF FIGURES

$\mathbf{x 1 1}$

$\begin{array}{lll}1.0 & \text { INTRODUCTION } & 1\end{array}$

1.1 The Role of Energy Storage 1

1.2 Overview of the Electrochemical Energy Storage Program 2

1.3 ECS Program Planning

1.4 Program Structure

1.5 Report Structure 11

2.0 ELECTROCHEMICAL SYSTEMS APPLICATION STUDIES 13

2.1 Stationary Electrical Storage 1n Ut1lity Systeme 13

2.2 Solar System Battery Storage 16

2.3 EHV Battery Program 20

2.3.1 Battery Requirements for EV's 24

2.4 Battery Test Program and Fac1lities 31

2.5 Technology Analys1s and Transfer 36

$\begin{array}{ll}3.0 & \text { AQUE.OUS NON-FLOW BATTERIES }\end{array}$

$\begin{array}{lll}3.1 & \text { Lead-Ac1d Batterles } & 42\end{array}$

3.1.1 Stationary Lead-Ac1d Batterles 43

3.1.2 EV Lead-Ac1d Batterfes 46

3.2 Alkaline Batterles $\quad 52$

3.2.1 Iron/N1ckel-0x1de Batter1es $\quad 52$

3.2.1.1 Overview of Iron/N1ckel-Ox1de 57

Battery Statug

3.2.2 Zinc/N1ckel-0xide Batteries 58

3.2.3 Alkaline Battery Research 58

3.2.3.1 Iron Electrode Research 59

3.2.3.2 Zinc Electrode Research 61

3.2.3.3 Z1nc/N1ckel-0xide Battery Separator 64

3.2.3.4 N1ckel-0xide Electrode Research 68 
TABLE OF CONTENTS

$\underline{\text { Page }}$

$\begin{array}{ll}\text { 4.0 ALKALINE BATTERIES WITH GASEOUS REACTANTS } & 73\end{array}$

4.1 Hydrogen/Nicke1-0xide Battery 73

$\begin{array}{lll}4.2 & \text { Iron/A1r Battery } & 75\end{array}$

4.3 Aluminum/A1r Battery 80

5.0 FLOW BATTERIES 93

5.1 Zinc/Bromine Battery 93

5.2 Zinc/Chlorine Battery 96

5.3 Zinc Deposition 1n Ac1dic Electrolytes 97

$\begin{array}{ll}5.4 \mathrm{Zinc} / \text { Ferricyantde Battery } & 100\end{array}$

5.5 Chromous/Ferr1c Redox Battery 104

$\begin{array}{lll}6.0 \text { NON-AQUEOUS BATTERY SYSTEMS } & 106\end{array}$

$\begin{array}{lll}6.1 & \text { Organic Electrolyte Batterles } & 106\end{array}$

6.1.1 Sulfolane Electrolyte Batterfes 106

6.1.2 Conducting Polymeric Electrode Cells 107

6.1.3 Organfc Electrolyte Battery Research 108

6.2 Molten Salt Systems 111

6.2.1 L1-alloy/FeS Batteries 111

6.2.2 Research on L1-alloy/Metal Sulf1de Batterles 113

6.2.3 Research on Alternative Molten Salt Cells 117

6.3 Solld Electrolyte Batterles 118

6.3.1 Sodium/Sulfur Battery $\quad 119$

6.3.1.1 Beta"-alumina Research 125

6.3.1.2 $\mathrm{Na}_{2} \mathrm{~S}_{\mathrm{x}} / \mathrm{S}$ Transport Properties 130

6.3.1.3 Corrosion in Polysulfide Melts 130

6.3.2 Sodium/Trichlorosulfonium Ion Ce1l 134

6.3.3 Novel Solld Ionfc-Conductor Research 135 
7.1 Fue1-Cell Technology

7.2 Methanol Reforming

7.3 Fue1-Cell Membrane Research

7.4 New Ac1d Electrolytes

147

7.5 Fue1-Cel1 Electrocatalysis

8.0 ELECTROCHFMICAL ENGINEFRING AND TECHNOLOGIES 154

8.1 Electrochemical Engtneer1ng

8.2 Electrochemical Technologies 


\section{LIST OF TABLES}

TABLE NUMBER

$\underline{\text { Page }}$

1 BATTERY TECHNOLOGY STATUS AND POTENTIAL 6

2 BATTERY TECHNOLOCY NEEDS

3 EV BATTERY PROGRAM GOALS 23

4 TOTAL AND AVERAGE VEHICLE WEIGHT 25

5 BATTERY PERFORMANCE PARAMETERS 26

6 BATTERY AND VEHICLE COSTS 28

7 COMPARISON OF DRIVING CYCLES OF VEHICLE TEST 33 PROF ILES

8 BATTERY APPLICATION MATRIX (EXAMPLE) 38

9 LEAD-ACID LOAD-LEVELING BATTERY GOALS 44

10 NBTL TEST RESULTS OF EXIDE LOAD-LEVELING BATTERY 47

11 SEALED LEAD-ACID BATTERY CYCLE TEST SUMMARY 48

12 IRON/NICKEL-OXIDE BATTERY PERFORMANCE GOALS 53

13 RELATIVE IMPORTANCE OF THERMAL PARAMETERS 72

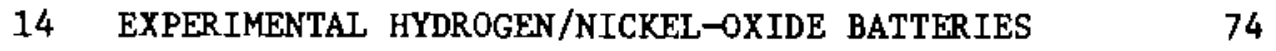

15 JPL ESTIMATES OF IRON/AIR BATTERY CHARACTERISTICS 78

16 Al/AIR BATTERY PROJECT ORGANIZATION 81

17 A1/AIr BATTERY WEIGHT ESTIMATION 86

18 A1/AIR CATHODE PERFORMANCE 89

19 METAL SULFIDE EQUILIBRIUM POTENTIAL AND 116 NUCLEATION OVERPOTENTIALS 


\section{LIST OF TABLES (concluded)}

TABLE NUMBER Page

20 ELECTRIC VEHICLE ENGINEERING MODEL-1 DESIGN GOALS 123

21 BETA"-ALUMINA TEST MATRIX 126

22 ANL CORROSION TEST RESULTS 132

23 GLASS COMPOSITIONS AND PROPERTIES 137

24 KEY TO FIGURE $11 \quad 143$ 


\section{LIST OF FIGURES}

FIGURE NUMBER

$\underline{\text { Page }}$

1 FUNDING BY TECHNOLOGY ARFA (TBR) 10

2 FUNDING BY ELEMENT (ETD) 12

3 BATTERY BREAKEVEN CAPITAL COST ( 5 -hr . BATTERY)

4 SOLAR-ARRAY/BATTERY ENERGY PROFILE 19

5 IMPACT OF RANGE AND DOD ON LIFE-CYCLE COST 30

6 NBTL DERIVED RAGONE PLOTS FOR AQUEOUS MOBILE 35

7 MACROCYCLIC CROWN ETHERS $\quad 67$

8 A1/AIR WEDGE CELL SCHEMATIC 82

9 Al/AIR BATTERY SYSTEM SCHEMATIC 85

10 RAGONE PLOT FOR Na/S EV CELL 122

11 SPER CELL HARDWARE CROSS SECTION 142 


\subsection{INTRODUCTION}

Th1s 1s the fifth in a series of reports on the status of the Department of Energy (DOE) program on battertes and electrochemical technologies for energy conservation. The research and development aspects of this program are conducted by the Energy Storage Division (STOR) of the Office of Energy Systems Research (ESR). The evaluation of the resulting battery developments are conducted in collaboration with the Electrical Energy Systems Program (EES), the Electrlc and Hybrid Vehicle Program (EHV), and the Renewable Energy Program (RE) of DOE.

The four preceeding reports (referencea 1-4) reviewed the status of the ECS program as of June 1978, December 1979, June 1981, and December 1982, resp. These reports 1ncluded background on battery storage program objectives, battery and electrotechnology research and development, summarles of the assessments of the potential contributions of batteries and electrotechnologies to energy conservation, and the economics of the introduction of batteries in the utility, transportation, and commercial sectors of the national economy.

This report is based on the status of the battery storage program at the time of the 6 th DOE Battery and Electrochemfcal Contractor's Conference (BECC-6) held June 25-29, 1984.

The goals of this and the earlier reviews, as expressed by Albert $R$. Landgrebe, the program director, were:

- to discuss progress that has been made to date (June 1984)

- to delineate those electrochemical topics in which further research might prove frutful in expediting the development and englneering of these systems

- to 1dentify new R\&D thrusts

\subsection{The Role of Energy Storage}

Alan J. Streb, DOE Deputy Assistant Secretary for Conservation, noted in his welcoming remarks that energy storage, in general, and electrochemical technology, in particular, contribute in a significant way to the overall enhancement of energy use effictency. The Federal role is to encourage Improved energy efficlency through conservation by helping to provide a good technical and economic environment. Cooperation between government and Industry is essential to stimulate the development of technologies leading to energy conservation. 
The 1mproved energy effictency brought about by conservation is evidenced by the 20 percent decline, since 1973, in the energy requlrement to produce a constant dollar of gross national product. This emphasizes the prominence that energy conservation plays in the overall national energy plan.

The Electrochemical Energy Storage (ECS) Program is one of the DOE conservation efforts orlented toward providing the technology base required for the more effective application of electrochemical systems to vartous end-uses. The primary need is to develop the technology for rechargeable batterles for energy storage. The ECS research activities are designed to ensure the avallability of the technologles that will permit the orderly development of electrochemical systems. These are targeted for eventual use in transportation, electrical network, solar energy, and industrial energy systems.

The transfer of technology is a major activity of the ECS program. Recent examples of technology transfer Include:

- the development of a maintenance free 6V, 100 Ah lead-ac1d battery which is being marketed by Gould

- the development of a platinum-based alr electrode for which ELTECH Systems has funded a pllot plant to demonstrate applicabllity to the chlor-alkall process

- the inttlation of an A1r Force program to develop the sodium/sulfur battery for satellite power

Streb was highly optimistic regarding the potential markets for electrochemical energy storage systems. One such market that requirea succeseful battery developments is transportation. Another potential market is for load-leveling in ut1lity systems. Streb also expressed the bellef that it is no exaggeration to say that we are in the formative stages of an entirely new energy storage Industry with all that enta1ls--jobs, profits, and benefictal effects on our balance of trade--to name just a few.

\subsection{Overview of the Electrochemical Energy Storage Program}

The alm of the Electrochemlcal Energy Storage (ECS) Program, according to Landgrebe, is to develop energy storage technologies that will assist the private sector in providing efficient, rellable, economlc, safe, and environmentally acceptable technology to: 
- underpin Industrial development of electrochemical power sources for transportation

- Increase the operating economy of electric utilities through load leveling

- enable intermittent renewable resources to provide continuous service

- Increase productivity by improving the efficlency of industrial electrochemical processes

The ECS program supports activities in Technology Base Research (TBR) and Exploratory Technology Development and Test1ng (ETD). Technology base research encompasses fundamental research to provide the basis for Improvements in existing battery systems and the identification and development of new battery and fuel-cell systeme. Crosscutting electrochemical and materials research in support of battery and fuel-cell development programs is also conducted. The ETD activity includes the development and evaluation of high performance, long-life, economical, and productble batterles for future mobile and stationary energy storage applications. This activity is designed to fill the gap between fundamental research on promising electrochemical systems and the product engineering capab111t1es of 1ndustry.

Results of the ECS program leading to technology transfer reported by Landgrebe, In addition to those noted by Streb, include:

- mathematical modeling of the Hall-Heroult cell for the electrolytic preparation of aluminum which has shown opportunities for a 4-25 percent improvement in cell efficiency

- Improvements in the lead-acid battery which are being introduced into commerclal batteries:

a) single-polnt watering for maintenance cost reduction

b) plastic grids for weight and cost reduction

c) gas recombination to reduce maintenance and to Improve safety

d) 1mprovements in active material formulation

e) charging system 1mprovements to reduce charging time without reducing life

In addition, the continued development of several technologies has been undertaken by industry or mission-oriented government agenctes. Examples include: 
- the $z$ inc/chlorine battery has been integrated into an electric vehicle by Energy Development Associates (EDA) and a $500 \mathrm{kWh}$ zinc/chlorine battery $1 \mathrm{~s}$ under test at the Battery Energy Storage Test (BEST) Facility

- Ford Aerospace has cost shared in the development of a 100 $\mathrm{kWh}$ sodium/sulfur battery

- the Prototech developed hydrogen electrode for the electrowinning of zinc is being evaluated by Exxon in a pllot plant

- Standard 011 of Ohio (SOHIO) has completed negotiations for exclusive rights to the NASA developed chromous/ferric Redox battery technology

Based on the recent rapld and successful developments in electrochemtstry, Landgrebe observed that electrochemistry can be safely said to be one of the most promising branches of chemlstry. Theoretical studies of the mechanism of metal corrosion in agressive media is an immediate task with great potential for cost reduction and energy savings. Corrosion research requires the use of a vartety of methods and approaches because of the number of disciplines and the complexity of the problems involved. The future progress of theoretical and applied electrochemistry will probably be connected with acquiring greater and deeper knowledge of the chemical stages in electrochemical processes.

\subsection{ECS Program Planning}

James E. Quinn, DOE, reviewed the Office of Energy Systems Regearch (ESR) planning activities as they relate to the ECS program. The boundary conditions for this planning are the National Energy Pollcy Plan and the DOE guidance based on this policy. Within these boundary conditions, the DOE program is directed toward:

- fosterlng an adequate supply of energy at reasonable cost

- minimizing Federal control and involvement in energy markets

- promoting a balanced and mixed energy resource system

The Federal role in research and development is to concentrate in areas where the energy-use potential is high and the incentives for and the avallability of private 1nvestment are severely 11mited or non-existent. The strategy of the Electrochemical Energy Storage Program is to: 
- identify requirements for batteries and electrochemical processes in applications which include electric vehicles, ut1lity load-leveling, and stationary energy storage

- provide a technology base for advanced electrochemical processes, components, and materials

- develop promising technologies unt11 the concept is proven or disproven

- test and evaluate new systems in a controlled laboratory environment to verify performance

- transfer technical information to industry to assure further product development and commercial use

The general planning process assesses opportunitles for application, reviews technical status and potential, establishes technology needs, develops and scopes program options, evaluates and prioritizes projects, and selects programs within the budget constraints. The major applications, requirements, and current and projected technology capabilities for batterles are given in Table 1.

Research needs in the electrochemical program have been determined by experts from industry, academia, government, and DOE National Laboratories. Through the use of topical seminars, meetings, and Industry groups, e.g., the Electric Power Research Institute (EPRI), areas of basic and applied technology needs have been 1dentified. These are listed in Table 2 .

An evaluation process is used to rank projects and define programs within given budget constraints. The ranking criteria include :

- Impact on energy use

- contribution to U.S. compet1tive position

- contribution to national defense

- environmental and other societal benefits

- probab111ty of technical and market success

- cost and economics

- appropriateness of federal role 
TABLE 1

BATTERY TECHNOLOGY STATUS AND POTENTIAL

\begin{tabular}{|c|c|c|c|c|}
\hline Requirement & $\begin{array}{l}\text { Electric } \\
\text { Vehicle }\end{array}$ & $\begin{array}{c}\text { Electric Utility } \\
\text { Load } \\
\text { Leveling }\end{array}$ & $\begin{array}{l}\text { Remote } \\
\text { Stand-Alone } \\
\text { (Solar) }\end{array}$ & $\begin{array}{l}\text { Residential } \\
\text { Grid-Connected } \\
\text { (Solar) }\end{array}$ \\
\hline Capacity & $20-50 \mathrm{kWh}$ & 20 to $100 \mathrm{MWh}$ & $100 \mathrm{kWh}$ & $25 \mathrm{kWh}$ \\
\hline Footprint & Not Applicable & $80 \mathrm{kWh} / \mathrm{m}^{2}$ & Not Appilcable & Not Applicable \\
\hline Efficiency & $70 \%$ & $65 \%$ & $70 \%$ & $70 \%$ \\
\hline LIfe & $\begin{array}{l}6 \text { years } \\
1600 \text { cycles }\end{array}$ & $\begin{array}{l}30 \text { years } \\
7500 \text { cycles }\end{array}$ & $\begin{array}{l}20 \text { years } \\
6000 \text { cycles }\end{array}$ & $\begin{array}{l}20 \text { years } \\
6000 \text { cycles }\end{array}$ \\
\hline Spectfic Power & $130 \mathrm{~W} / \mathrm{kg}$ & Not Applicable & Not Applicable & Not Applicable \\
\hline
\end{tabular}

Source: Reference 5 (QuInn) 
TABLE 2

BATTERY TECHNOLOGY NEEDS

Technology Base Research

- Develop and characterize new catalysts with high activity, long life, and low cost.

- Perform research on electrochemical corrosion processes.

- Develop an aluminum/air battery system which offers the potential of power1ng a vehicle 300 miles or more between mechanical recharges.

- Investigate catalysts, electrode structures, electrolytes, and advanced reformers for alkaline, phosphoric acld, and solld polymer electrolyte fuel cell systems for transportation.

- Research additional metal/air battery systems including zinc/a1r and iron/air.

- Develop Iong-life, efficlent, low-cost battery systems for stationary storage applications including zinc/ferricyanide and hydrogen/nickel-oxide system.

- Research intermediate-temperature molten salt systems, lith1um/ metal-disulfide batteries, and thermally regenerative batteries.

- Research the organic electrolyte lithim battery systews as these offer the highest theoretical specific energy of any battery under development.

Exp.Loratory Development and Testing

- Conduct R\&D on h1gh-performance sod1um/sulfur battery systems that can lead to safe, rellable, and efficlent cells and modules.

- Develop a zinc/bromine battery system emphasizing increased performance, low cost, and increased life.

- Provide factlities for testing and evaluating secondary battery systems.

- Develop a battery performance data base and analysis of failure modes to 1dentify wajor problem areas.

Source: Reference 5 (Quinn) 
After inftial rankings and presentation of appropriate data, projects are split into various funding levels and reordered by management judgement.

\subsection{Program Structure}

The current ECS program, as stated by Landgrebe, consists of two major activities:

- Technology Base Research (TBR)

- Exploratory Technology Development and Test1ng (ETD)

The responsibility for TBR activities has been assigned to the Lawrence Berkeley Laboratory (LBL) at the University of California, and that for ETD activities to Sandia National Laboratories (SNL). The fiscal year 1984 and the projected 1985 budgets are:

$\begin{array}{ccc} & \begin{array}{c}1984 \\ \$ M\end{array} & 1985 \\ & \$ M \\ \text { Technology Base Research } & 7.4 & 9.35 \\ \begin{array}{c}\text { Exploratory Technology } \\ \text { Development and Test1ng }\end{array} & 10.6 & 7.5 \\ \quad & & \\ \text { Total } & 18.0 & 16.85\end{array}$

Battery systems, which have been characterlzed earlier in the ECS program and have demonstrated performances that can be extrapolated to meeting the requirements for a specific application, have become the responsibility of the respective program of the office of Energy Systems Research of the Office of Energy Conservation (EC) of the DOE. The status of the evaluation and testing of these

batteries for specific applications is reviewed in Section 2 of this report and technology detalls in Sections 3 through 8 .

The LBL TBR activity supports the DOE effort to provide the basic and applied research required to establish the technology base for the stationary storage and electric vehicle applications. (5) The primary objective of the TBR is to 1dentify the most promising electrochemical technologies and transfer these technologies to the ETD activity or to one of the DOE end-use programs for ultimate transfer to 1ndustry for possible commerclalization. The TBR actlvity is subdivided into general research and applied research.

The general research areas of the TBR activity include: 
- Identification of new electrochemical couples for advanced batteries

- determination of the technical feasibility of new couples

- 1mprovements in battery components and materials

- establishment of engineering principles applicable to electrochemical energy storage and conversion

- Investigation of fuel-cell technology for transportation applications

The applied research aspects of the TBR activity are targeted toward batteries that will lead to superior performance and lower life-cycle costs. The principal applied research topics of the TBR activity include:

- electrochemical studies of new reversible electrochemical couples and metal/alr cells

- supporting research which includes the engineering and modellng of cells and cell components and research on cell materlals

- electrochemical processes Including corrosion in electrochemical systems, three phase electrochemical systems, and non-electrochemically-regenerative cells

- fuel-cell (FC) research emphasizing systems for transportation

The distribution of the fiscal year 1984 (FY '84) funds among the TBR areas is shown in Figure 1.

The objective of the ETD activity at SNL is the development and evaluation of high-performance, long-life, economical, and producible batterles for mobile and stationary atorage applications. (5) This activity is designed to bridge the gap between the TBR basic and applied research efforts and commercialization. The ETD activity follows-up on the battery couples, materials, and engineering shown to be promising by the TBR activity. The ETD activity consists of five elements:

- aqueous batterles

- nonaqueous batterles 


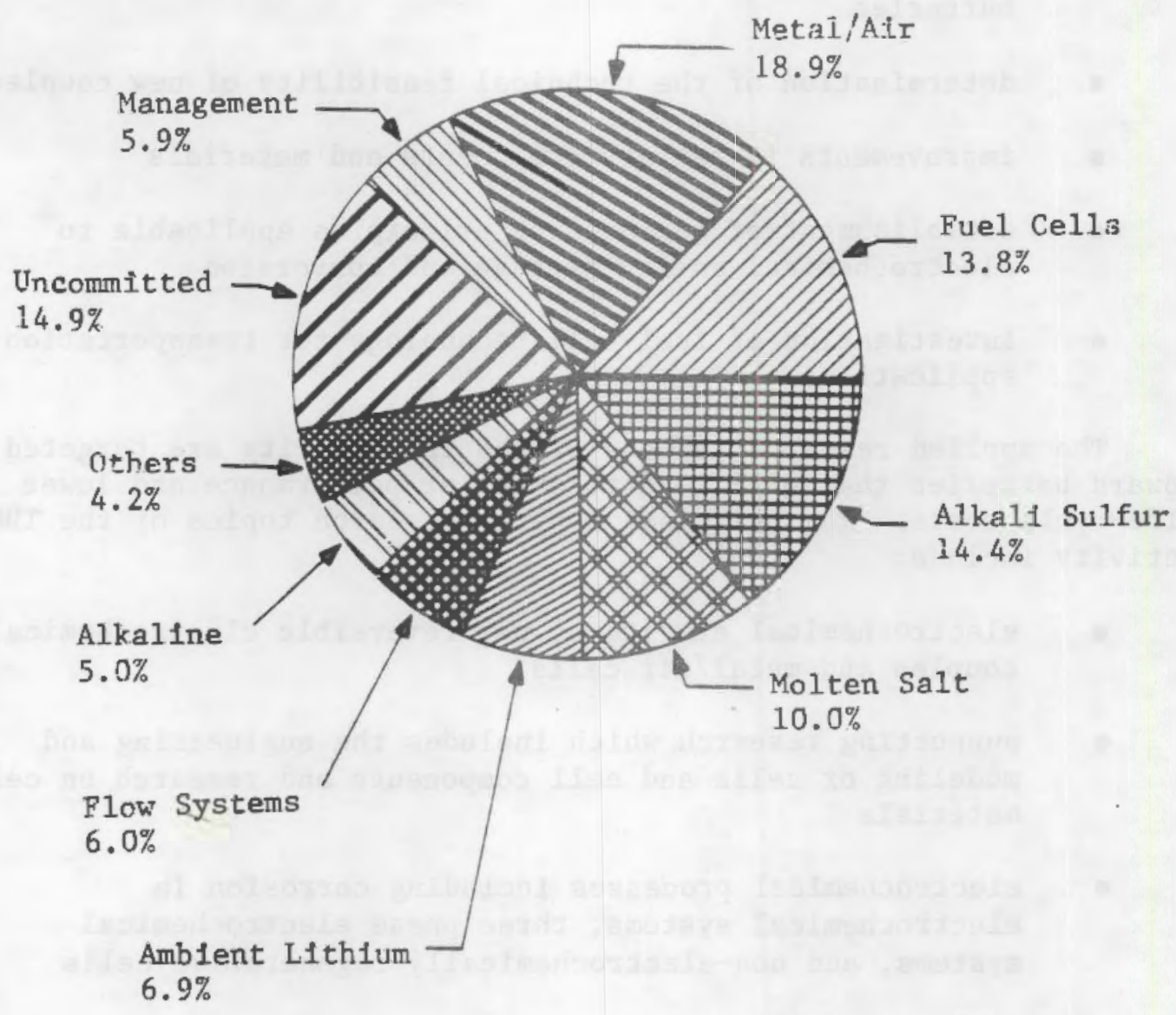

Total Activity

$\$ 7.4 \mathrm{M}$

FUNDING BY TECHNOLOGY AREA (TBR)

FY 1984

FIGURE 1 
- engineering analysis

- performance testing and evaluation

- project analysis

The planned distribution of FY ' 84 funds among the ETD activity elements is shown in Figure 2.

The evaluation of the performance of the improved and advanced batteries in stationary and transportation systems, as previously noted, is partly or wholly supported by other programs of the Office of Energy Conservation.

\subsection{Report Structure}

Th1s review of the ECS program will not adhere to the management organization of the program. The technology and research on specific battery systems are integrated. Generic research is reported in the technology section most closely related to the research or in Section 8.

The battery couples w111 be written: negative/positive. When the electrolyte is included the components will be written: negative/electrolyte/positive. The major exception will be the lead-acid battery for which the common name w111 be used.

The primary source of the information summarized in this report was the extended abstracts published as part of the proceedings of the "Sixth DOE Electrochemlcal Contractor's Review" (BECC-6) held 25-29 June $1984^{(5)}$. Th1s has been supplemented by 1nformation from the project summaries issued as part of BECC $-6,(6)$ the annual sumarles of the TBR and ETD activities, $(7,8)$ and varlous publications. 


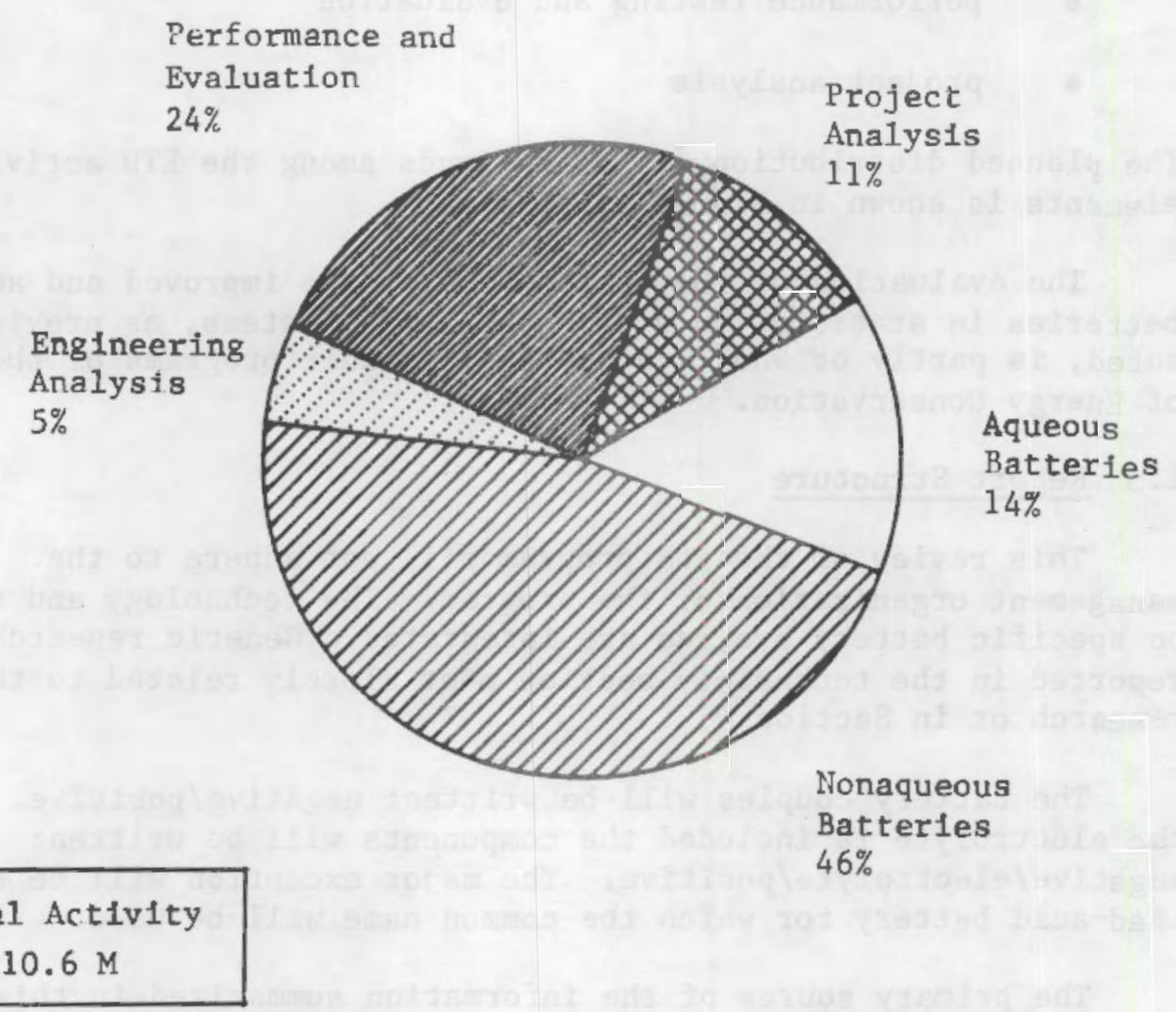

FUNDING BY ELEMENT (ETD)

FIGURE 2 
The majority of the battery applications and electrochemical technologies activities, previously wholly or partially included in the ECS program, which are not being continued by industry or another federal agency, have been transferred to the DOE end-use programs or discontinued. Current ECS efforts on stationary storage are targeted toward solar systems - photovoltaics and wind power and on electrochemical storage for utility systems.

\subsection{Stationary Electrical Storage in Ut1lity Systems}

The remalning effort on the evaluation of battery energy storage for load-leveling in electrical utility systems is the operation of the Battery Energy Storage Test (BEST) Fac1lity. At this facility testing of battery storage under utility operating conditions and the evaluation of battery storage for application to utility systems is conducted. The sponsors of the BEST Facility Include DOE Electric Energy Systems (EES), the Electric Power Research Institute (EPRI), and the Public Service Electric and Gas Company (PSE\&G). The BEST Fac1lity serves energy technology developers, electric utilities, and the project sponsors. The test program, described in reference 2, was based on schedules developed jointly among the program sponsors, equipment suppliers, and PSE\&G. The BEST Facility provides for testing of batterles, ac/dc power conversion equipment, and of complete battery energy storage systems.

The BEST Facility operation of a base-11ne system during 1982-1983 was reported to have given the first usefui Information regarding the characterlstics of a utility operated battery energy storage system. (5) The base-1ine system consists of a $1.8 \mathrm{MWh}$ state-of-the-art ( $\mathrm{SOA}$ ) lead-acid battery, a $2.5 \mathrm{MW} \mathrm{ac} / \mathrm{dc}$ converter, and a control and data processing computer system. It operates in a $13.8 \mathrm{kV}$ interconnection with the PSE \&G electric distribution grid. The tests conducted included repetitive cycling in elght different application modes representing typlcal operations. These tests were successful. They verifled that a SOA battery energy storage system can provide load-leveling, peak shaving, spinning reserve, loadfollowing, and special customer applications functions. A 75 
percent $\mathrm{dc} / \mathrm{dc}$ energy conversion efficiency was achieved, this efficlency included the overcharge energy. A total of $200 \mathrm{MWh}$ of energy were exchanged with the PSE\&G distribution grid.

The SOA lead-acid battery was conflgured as a series string of 64, $12 \mathrm{~V}$ modules. The battery was typically discharged to provide an average power of $400 \mathrm{~kW}$ at $730 \mathrm{~V}$. No difficultles were encountered in operating at higher voltages (1000 Vdc) or at lower voltages $(250 \mathrm{~V} \mathrm{dc})$. The observed temperature varlation in the batterles during cycling was within a safe value. However, it was observed that the battery tops on the positive side lifted, indicating positive plate growth.

The BEST operation of the SOA lead-acid battery gave facility operating personnel experfence in battery storage systems operation, and in the use of the on-line monitoring and control system. Based on the test results, it was concluded that SOA lead-acid batteries with the associated conversion equipment can perform the many applications required by electric utilities and thelr customers. Future operations of the BEST Facility are expected to give valuable Information on battery 11 fe and operating and maintenance costs.

PSE\&G has also completed the test bay for the installation of a $500 \mathrm{kWh} z 1 \mathrm{nc} / \mathrm{ch}$ lorine battery. The development and operation of this battery, Including a description of the $50 \mathrm{~kW}$ modules used, has been revlewed in the preceeding status reports, references 1 through 4, and in Energy Development Associates (EDA) reports to DOE and EPRI. The battery system was Installed at the BEST Facility by EDA during August 1983. A nine-month zinc/chlorine developmental test program was initiated in February, 1984. This test phase is to verify operation and maintenance procedures and to obtain test data under operating conditions in a user environment. The zinc/chlorine battery completed 30 baseline cycles (April 1984); the baseline cycles consisted of seven hours of charge and five hours of discharge without a "charged-stand" period. The average dc/dc energy efflclency was 62 percent. The projected ac/ac efflclency for a commercial, optimized battery energy storage system operating under utility conditions $1 \mathrm{~s}$ estimated by the developer as 7-10 percent lower than the dc/dc efficlency.

A $500 \mathrm{kWh}$ (one-hour rate) 1oad-leveling GNB Batterles, Inc. lead-acid battery has also been supplied for testing. The battery was procured by EPRI. Testing was inititated in February 1984. Midway in the nine-month test program a matched ac/dc converter and control unit are to be added to the test system. This will enable the evaluation of a battexy designed for load-leveling. The battery is rated as having an eight-year, two-thousand cycle $11 f e$. 
Future BEST plans include the testing of a sodium/sulfur, a

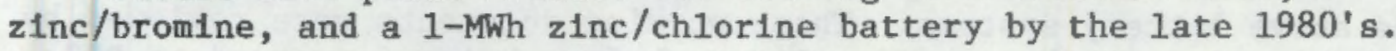

PSE\&G is also working on a project titled, "Technical and Economic Assessments of Electrochemical Energy Storage Systems." (5) The major tasks and the areas included are:

- Task 1 - Overall Technical Assessment

An overall technical assessment of four advanced batteries zinc/chlorine, zinc/bromine, sodium/sulfur, and lead-acid has been completed. These batteries were evaluated with respect to the design and engineering, total battery plant costs including balance of plant, rellabllity of the overall battery facllity, efficlency of the facility, environmental and regulatory 1ssues, and credible accident assessments.

- Task 2 - Syatem Stability Impact Assessment

A simulation of system response in which all components affecting system stability and dynamic performance are represented. The EPRI Transient/M1d-Term Stabllity Program was used in this assessment.

- Task 3 - Overall Economlc Assessment

An overall economic assessment of battery systems on generation planning representing breakeven costs of battery plants with respect to varlous parameters such as capital costs, escalation, load factor, efflclency, plant life, salvage value, charge hours, storage hours, and effective forced outage ratio has been completed.

- Task 4 - Battery Cost Methodology

A battery cost methodology and sensitivity analysis of the critical cost components for the battery and balance of plant was completed for zinc/chlorine, zinc/bromine, sodium/sulfur, and lead-acld batterles.

Background information for Task 1 was obtained directly from the battery developers. This included data on the battery conflguration, battery operation, auxiliary systems, and cost of a 100 Mh plant. The Information was used by the PSE\&G staff to develop the balance of plant (BOP) interface for each of the battery systems. Based on these results, working documents were prepared which contained the design, plant description, and cost for each of 
the above battery systems. These working documents were reviewed by the participating battery developers before being forwarded to DOE for comment.

In Task 2, a system stability impact assessment was performed through the development of valid mathematical models for the storage battery and assoclated AC/DC conversion equipment. The equations were solved using a digital computer program. Both 1ine-commutated and self-commutated (forced-commutated) converter systems were modeled. A large number of computer runs have been made covering a variety of disturbances under various operating conditions in a large reference power system. The regults suggested that the battery storage systems are not likely to have significant impact on a power system.

The Task 3 results on the breakeven cost relationship as a function of battery penetration for the "base" study assumptions are shown in Figure 3. The breakeven cost for batterles is the 1nstalled capital cost of a battery plant which is economically equivalent to a conventional capacity option. The three components of the breakeven cost: peak shaving, spinning reserve, and capacity credits are shown in Figure 3 . The results show a marked decrease in the battery breakeven capital cost as battery penetration increases. A sensitivity analysis of the battery breakeven costs for variation in battery plant characteristics, utility system characteristics, and financial data is also reported.

In Task 4, the battery cost methodology covers the battery and balance of plant. The battery cost methodology was primarily based on A.D. Little Standard Costing Methodology. The BOP cost methodology was based on standard utility practice and experience. A sensitivity analysis of the critical cost components was performed for each battery type. This analysis represents the fluctuation of cost impact on the battery and BOP costs.

\subsection{Solar System Battery Storage}

The SNL fleld testing program for the battery electrical storage component of solar energy systems (photovoltaic and wind) was described in reference 4 and 1 ts status is up-dated in this report. The SNL test results on specific batteries for solar energy systems are included in the technology sections.

A stand-alone battery and photovoltaic residential power test Is located on the Jicarilla Apache Indian Reservation. This test is sponsored by the Public Health Service. The system consists of a 490 watt photovoltaic array and $24 \mathrm{kWh}, 24 \mathrm{~V}$ battery. When the array cannot supply the demand, the required supplemental power is 


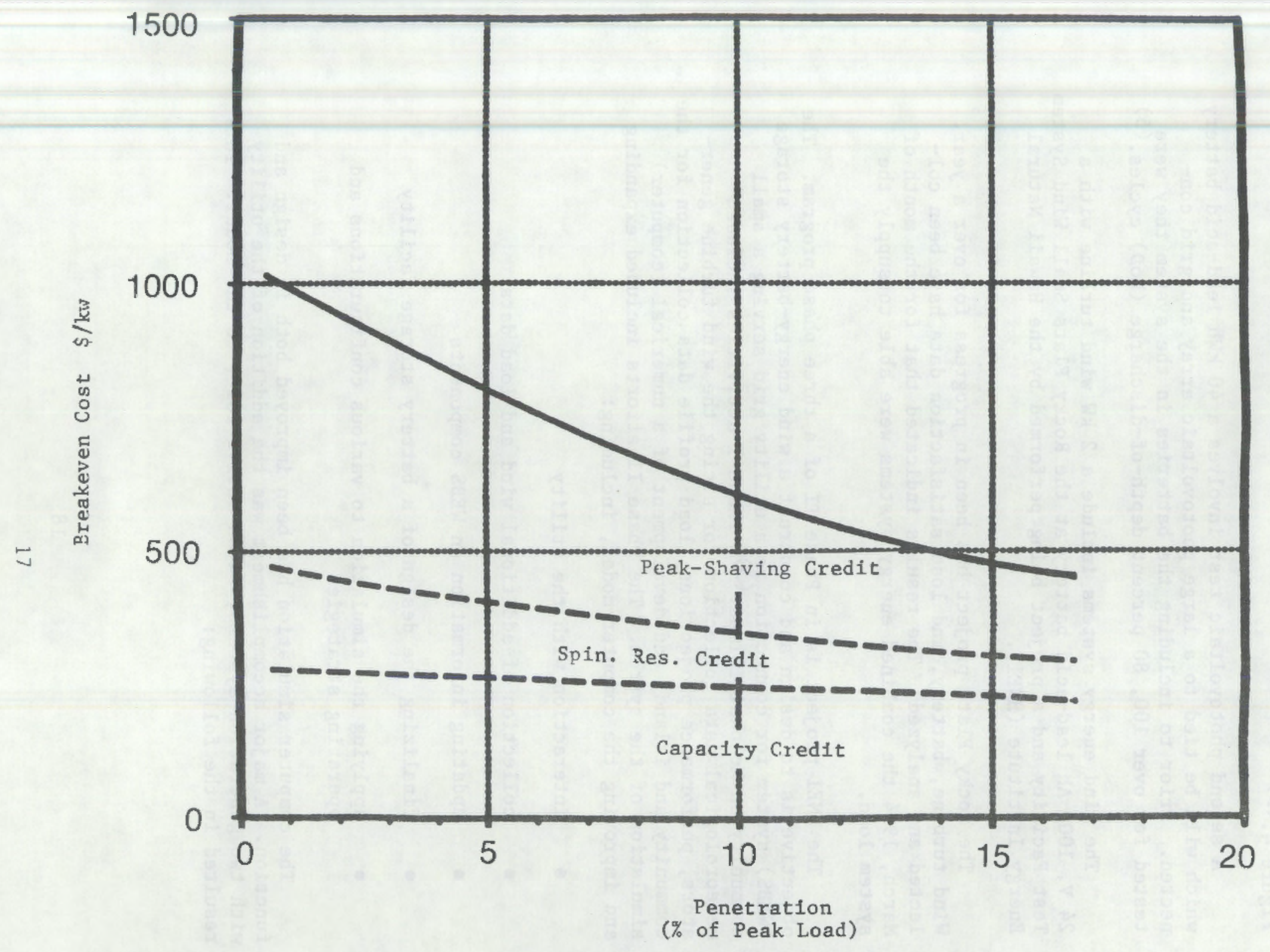

BATTERY BREAKEVEN CAPITAL COST

(5-HR. BATTERY)

FIGURE 3 
obtained from the battery. This system is being monitored to obtain battery performance data, and the energy mix between the photovoltaic array and battery for a dally load profile is shown in F1gure 4.(5)

A second photovoltalc test 1nvolves a $40 \mathrm{kWh}$ lead-acld battery which will be tied to a large photovoltalc array and grid connected. Prior to including the batteries in the system they were tested for over 100,80 percent depth-of-discharge (DoD) cycles. (5)

The wind energy systems include a $2 \mathrm{~kW}$ wind turbine with a 24 V, 1000 Ah lead-acld battery at the Rocky Flats Small Wind System Test Facility and a project being performed by the Hawali Natural Energy Inst1tute (HNEI).

The Rocky Flats project has been in progress for over a year. Wind turbine, battery, and load satisfaction data have been collected and analyzed. The results indicated that for the month of March, 1984 the comblned energy systems were able to supply the system load.

The HNEI project is in Phase II of a three phase program. The objective is to design and construct a wind energy-battery storage (WEBS) system for connection to a utility grid serving a small community on Molokal Island. (5) Phase I activities Included meteorological data collection for siting the wind turbine generators, performance projections, load profile data collection for the community and 1sland, and development of a numerical (computer) simulation of the system. The Phase II efforts included expanding and improving the computer model, including:

- Interaction with the utility

- collection of additional wind and load data

- updating information on WEBS components

- finalizing the design of a battery storage facility

- applying the simulation to various configurations and operating strategles

The computer simulation has been improved both in design and function. A major accomplishment was the addition of the utility with two generation systems, in an active role, to the model. This resulted in the following: 


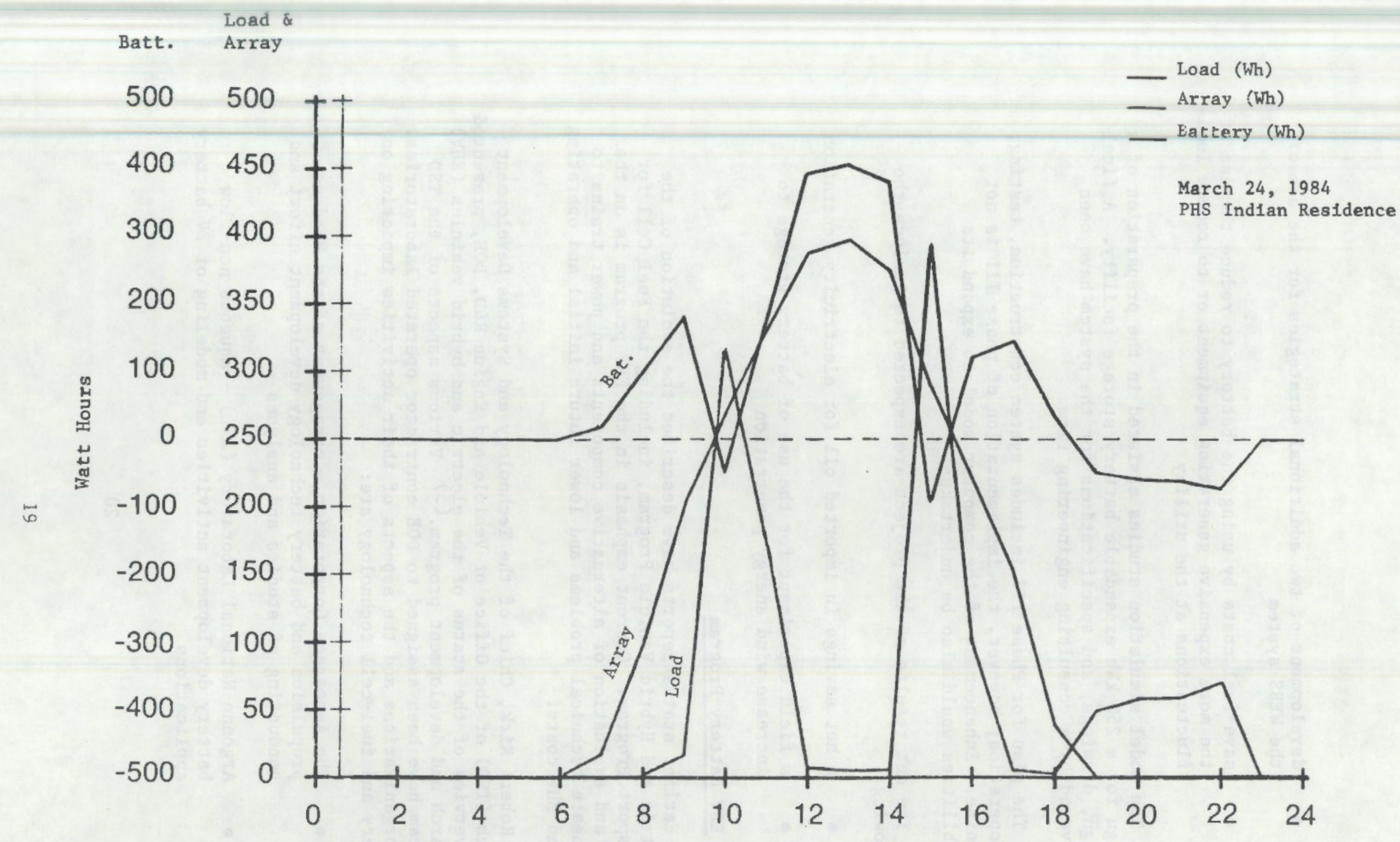

Hour of Day

SOLAR-ARRAY/BATTERY ENERGY PROFILE

FIGURE 4 
- development of two additional strategies for the use of the WEBS system

- save fuel costs by using the battery to reduce the use of the more expensive generating equipment or to reduce load fluctuations at the utility

The model simulation studies assisted in the preparation of a design for a $250 \mathrm{kWh}$ expandable battery storage facility. A final design, drawings, and specifications for the system have been dellvered by a consulting engineering firm.

The plan for Phase III includes system construction, testing, and operation; however, the implementation of phase III 1s not definite. Enhancement of the computer model to expand 1ts capabilities would also be undertaken.

The net results of the project are expected to include the following:

- a net savings in imported oll for electricity generation

- a fleld experiment for the use of battery storage to increase wind energy penetration

\subsection{EHV Battery Program}

Earlier status reports have described the evolution of the Electric and Hybrid Vehicle Program, including the Fuel Cell for Transport Program. Current emphasis in the EHV program is on the test and evaluation of alternative components and power trains to delineate technical problems and lower future initial and operating EV and EHV costs.

Robert K1rk, Chief of the Technology and Systems Development Branch (TSD) of the Offlce of Vehicle and Engine R\&D, DOE, presented an overview of the status of the electric and hybrid vehicles (EHV) research and development program. (5) Various aspects of the TSD program have been assigned to DOE contractor operated laboratorles. The organizations and the aspects of their activities impacting on battery and fuel-cell technology are:

- The Aerospace Corporation - management of the Ford ac propulsion and battery technology development effort and conducting of studies and analyses

- Argonne National Laboratory (ANL) - aqueous non-flow battery development activities and modeling of EV battery applications 
- Jet Propulsion Laboratory (JPL) - management and testing of vehicles system and propulsion subsystem and advanced technology assessments

- Sandia National Laboratories (SNL) - management of the zinc/bromine EV battery systems development

Los Alamos National Laboratory (LANL) - management of fuel cells for transport program

The cooperative program with the Lewis Research Center of the National Aeronautics and Space Agency (NASA) was discontinued at the end of fiscal year 1983 and the agreement. with JPL is to conclude at the end of fiscal year 1984.

The specific objectives of the TSD program is to establish the technology base required for a totally or near-totally petroleumfree vehicle. Three types of vehicles are being emphasized:

- all-electric commerclal van, limited range

- all-electric passenger car, limfted range

- hybrid passenger car, unlimited range

The critical technology needs, with respect to batteries, enumerated by Kirk were:

- reduced cost

- Increased cycle life

- increased spectflc energy and spectfic peak power

- reduced degradation due to age and temperature effects

- reduced maintenance requirements

The TSD program contains a number of studies and analyses on the impact of various available and projected technologies on EV and EHV performance. These studies assist in establishing vehicle performance capabilitles and advances required to achleve performance obfectives. The study at JPL has assigned rankings for various batteries and fuel cells as the power source or part of a hybrid power plant for advanced electric vehicles.

Electric vehicle test results have shown that Electric Test Vehicle-1 (ETV-1), which was designed for mass production, using an advanced lead-acid battery was capable of achieving a range of 123 
$\mathrm{ml}(198 \mathrm{~km})$ at $35 \mathrm{mph}(56 \mathrm{~km} / \mathrm{h})$ and $90 \mathrm{ml}(144.8 \mathrm{~km})$ at $45 \mathrm{mph}(72$ $\mathrm{km} / \mathrm{h})$. The ETV-1 had a top speed of $70 \mathrm{mph}(113 \mathrm{~km} / \mathrm{h})$. The Ford Motor Company advanced ac propulsion system, wh1ch has a coaxial motor and transaxle (ETX), is to be tested using lead-actd, zinc/ bromine, and sodium/sulfur batteries. The Ford ETX vehicle has shown Improved performance when compared with the ETV-1. The Eaton advanced-van propulsion technology effort includes the use of 1ron/nicke1-oxide batteries.

Based on the in-vehicle tests and various system studies, battery performance and cost development goals have been established. These are shown in Table 3. Studies of batterles for hybrid vehicles indicate the need for a high power density battery, such as zinc/nickel oxide. Effort is being continued on advanced batterles and fuel cells for EV and EHV applications.

The EHV test and evaluation program, reviewed by Kenneth F. Barber (DOE, EHV), consists of three elements:

- vehicle site operations

- technology suftability testing

- engineering evaluation testing

Here the activities and results impacting on battery technology will be emphasized.

A group of vehicle s1te operators has formed a Users Task Force for selecting and evaluating technologies for eliminating present EV shortcomings. According to Barber the major problems with present technology are low rellability and high operating cost. (5) Battery 1ife is an important component of operating costs. However, the results of testing of some advanced batterles indicate that considerable progress $1 \mathrm{~s}$ being made in increasing battery $11 \mathrm{fe}$. The fleet operation has shown that the costs for current batterles can be reduced by conducting routine battery capacity checks and by the use of on-board systems to detect weak or defective modules enabling the tak1ng of corrective action before damage to the remainder of the battery pack. The fleet operation has also shown that watering of the lead-acid battery is labor intensive and significantly increases the operating cost. To help decrease this cost a watering wand has been developed and is being fleld tested. Preliminary results indicate a large, as high as 75 percent, decrease in watering time. An alternative route to decreased watering time is the gel-electrolyte battery to be discussed in Section 3.2. 
TABLE 3

EV BATTERY PROGRAM COALS

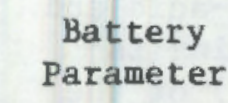

Specific Energy

Specific Power

Cycle Life
Cost (1981\$)

Reference 5 (K1rk)

\section{Developmental} Goal

$56 \mathrm{Wh} / \mathrm{kg}$

$104 \mathrm{~W} / \mathrm{kg}$

800 cycles

$\$ 70 / \mathrm{kWh}$

$(\$ 0.11 / \mathrm{kWh} /$ cycle $)$

\section{Expected Vehicle Performance}

$100 \mathrm{mi}(160 \mathrm{~km}) /$ charge in an urban driving schedule

Acceleration 0 to $30 \mathrm{mph}$ $(48 \mathrm{~km} / \mathrm{h})$ in $8 \mathrm{sec}$; hill climbing

$60,000 \mathrm{mile}(46,000 \mathrm{~km})$

life

$\$ 2000$ battery cost/ vehicle $7 t / \mathrm{mile}(4.8 \mathrm{t} / \mathrm{km})$ (life cycle) 
Characterization testing of the Hybrid Test Vehicle (HTV), under the engineering evaluation testing element, has been completed by the Jet Propulsion Laboratory. The results indicated a fuel economy savings of 44 percent over an annualized basis. The reference vehicle was a 1985 Buick of the same size as the HTV. Chassis dynamometer testing, using the ETV-1 and Jet-750 pickup as test vehicles, was carried out using the Globe EV-2300 lead-acid and the Eagle-P1cher 1ron/nickel-oxide batteries. Battery testing is also underway at the National Battery Test Laboratory (NBTL) of the Argonne National Laboratory (ANL). The charge/discharge studies of the Globe EV-2300 lead-acid battery are to determine the minimum overcharge requirement as a function of the depth-of-discharge. The pulse discharge characteristics of the Eagle-Picher Iron/nicke1oxide battery are being determined to ald motor controller destgners in synthesizing a circuit model with minimum energy losses. The effect of battery temperature and depth-of-discharge on cycle $11 \mathrm{fe}$ is also being investigated at NBTL.

\subsubsection{Battery Requirements for EV's}

William J. Walsh and William W. Marr, ANL, have developed a computer system to assist in the establishment of battery requirements for electric and hybrid vehicles. This program has been given the acronym "EVA". The computer program includes:

- mission-specified vehicle requirements

- comprehensive battery modeling

- avoldance of premature or unnecessary assumptions

- least-cost analysis

Equations were developed for calculating various weight, performance, and cost parameters for the battery and the vehicle. These relationships are shown in Tables 4, 5, and 6, reapectively.

Battery data used in the EVA program Included the 1984 performance of lead-ac1d and 1ron/nickel-oxide batterles and the 1990 performance for these batterles and several of the advanced batterfes based on projected 1990 technology. The advanced batterles include $\mathrm{Na} / \mathrm{S}, \mathrm{L} 1-\mathrm{Al} / \mathrm{FeS}, \mathrm{Zn} / \mathrm{Br}_{2}$, and $\mathrm{Zn} / \mathrm{Cl}_{2}$.

The results of the EVA program for the estimation of life-cycle cost vs. range as a function of DoD are shown in Figure 5. The EVA computer program is to be ready for users during the summer of 1984 and w11 be obtainable from ANL at no cost to USA requestors. 
TABLE 4

TOTAL AND AVERAGE VEHICLE WEIGHT

$$
\begin{aligned}
& w_{T}=\frac{w_{P L}+w_{B D}}{1-\beta_{D}-\beta_{F}-\beta_{B}} \\
& \bar{w}_{T}=w_{T}-(1-r) w_{P L}
\end{aligned}
$$

Where:

$W_{\mathrm{T}}=$ total vehicle weight $(\mathrm{kg})$

$\bar{w}_{\mathrm{T}}=$ average vehicle weight $(\mathrm{kg})$

$W_{\mathrm{PL}}=$ payload of vehicle

$W_{\mathrm{BD}}=$ weight of body

$\beta_{D}=$ weight fraction of drive-traln based on $W_{T}$

$\beta_{F}=$ weight fraction of frame based on $W_{T}$

$I=$ average fractional payload onboard

$\beta_{B}=$ weight fraction of battery based on $W_{T}$

Reference 5 (Walsh and Marr) 
TABLE 5

BATTERY PERFORMANCE PARMETERS

EV Battery Specific Power:

$$
\begin{aligned}
P_{B} & =\frac{P v}{\beta_{B} \eta_{V P}} \\
P_{B} & =\frac{E v R c}{\beta_{B} \eta_{V E} T_{C}}
\end{aligned}
$$

Spectfic Power vs. Specific Energy

$$
P_{B}=a_{0} \cdot E_{B}+\left(1 / 3-a_{0}\right) \cdot E_{3}
$$

Peak Power vs. Spectfic Energy and DoD

$$
P P=\left(a_{1}+a_{2} \cdot D O D\right) \cdot E_{3}+a_{3}
$$

Cycle L1fe vs. DoD

$$
\mathrm{L}_{\mathrm{B}}=\mathrm{L}_{\mathrm{B} 0} \cdot \mathrm{e}^{\alpha(1-\mathrm{DoD})}
$$

Where:

$$
\begin{aligned}
& P_{B}=\text { Peak specific power }(\mathrm{w} / \mathrm{kg}) \\
& P_{B}=\text { Average specific power }(\mathrm{w} / \mathrm{kg}) \\
& P_{V} \text { - Vehicle power-to-weight requirement }(\mathrm{w} / \mathrm{kg}) \\
& \eta_{V P}=\text { Vehicle drive-train power efficlency } \\
& \eta_{V E}=\text { Vehicle drive-train energy efficiency } \\
& \beta_{B}=\text { Battery welght fraction } \\
& E_{V}=\text { Vehicle energy consumption with distance }(\mathrm{Wh} / \mathrm{kg}-\mathrm{km}) \\
& R_{C}=\text { Range of a typical drive-cycle, } \mathrm{km}
\end{aligned}
$$


TABLE 5

BATTERY PERFORMANCE PARMETERS (concluded)

$T_{c}=$ Time period corresponding to $R_{C}$, hrs

$a_{0}=$ Ragone slope (Figure 6)

$\overline{\mathrm{E}}_{\mathrm{B}}=$ Average specific energy $(\mathrm{wh} / \mathrm{kg})$

$\mathrm{E}_{3}=$ Specif1c energy at 3-hour rate (wh/ $\mathrm{kg}$ )

$\mathrm{PP}=$ Peak power

$a_{1}, a_{2}, a_{3}=$ battery coefficients

DoD $=$ Depth of discharge

$L_{B}=$ Battery 11 fe cycles

$\mathrm{L}_{\mathrm{BO}}=$ Battery life at $\mathrm{DoD}=1.0$ cycle

$\alpha=$ Battery coefficients

Reference 5 (Walsh and Marr) 
Battery Costs

$$
C_{B}=C_{B 1}+C_{B 2} E_{T}+C_{B 3} P_{T}
$$

Vehicle First cost

$$
\begin{aligned}
& C_{V}=(\underbrace{\left(1+\delta_{D}\right.}_{\text {Dealer Markup }})\left\{[\underbrace{\left(C_{\mathrm{BD} 1}+\mathrm{C}_{\mathrm{BD} 2} \mathrm{~W}_{\mathrm{BD}}\right)}_{\text {Body }=\mathrm{BD}}]+[\underbrace{\left(\mathrm{C}_{\mathrm{D} 1}+\mathrm{C}_{\mathrm{D} 2} \beta_{\mathrm{D}} \mathrm{W}_{\mathrm{T}}\right.}_{\text {Dr1ve train }=\mathrm{D}})\right]+ \\
& {\left[(\underbrace{C_{\mathrm{F} 1}+\mathrm{C}_{\mathrm{F} 2} \beta_{\mathrm{F}} \mathrm{W}_{\mathrm{T}}}_{\text {Frame }})\right]+\left[(\underbrace{C_{\mathrm{T} 1}+\mathrm{C}_{\mathrm{T} 2} \mathrm{~W}_{\mathrm{T}}}_{\text {Tires }})\right]+} \\
& {\left[(\underbrace{\left.\left.C_{\mathrm{B} 1}+\mathrm{C}_{\mathrm{B} 2} \mathrm{E}_{\mathrm{T}}+\mathrm{C}_{\mathrm{B} 3} \mathrm{P}_{\mathrm{T}}\right)\right]+\mathrm{C}_{1 \mathrm{E}}+\mathrm{C}_{1 \mathrm{P}}}_{\text {Battery }}\}\right.}
\end{aligned}
$$

Replacement Cost of Components

$$
C_{R 1}=(\underbrace{1+\delta M}_{\text {Markup }}) \cdot C_{1} \cdot \underbrace{\exp (x t)}_{\text {Escalat1on }} \cdot \underbrace{\exp (-y t)}_{\begin{array}{c}
\text { Present- } \\
\text { worth }
\end{array}}
$$


TABLE 6

BATTERY AND VEHICLE COSTS (concluded)

Where:

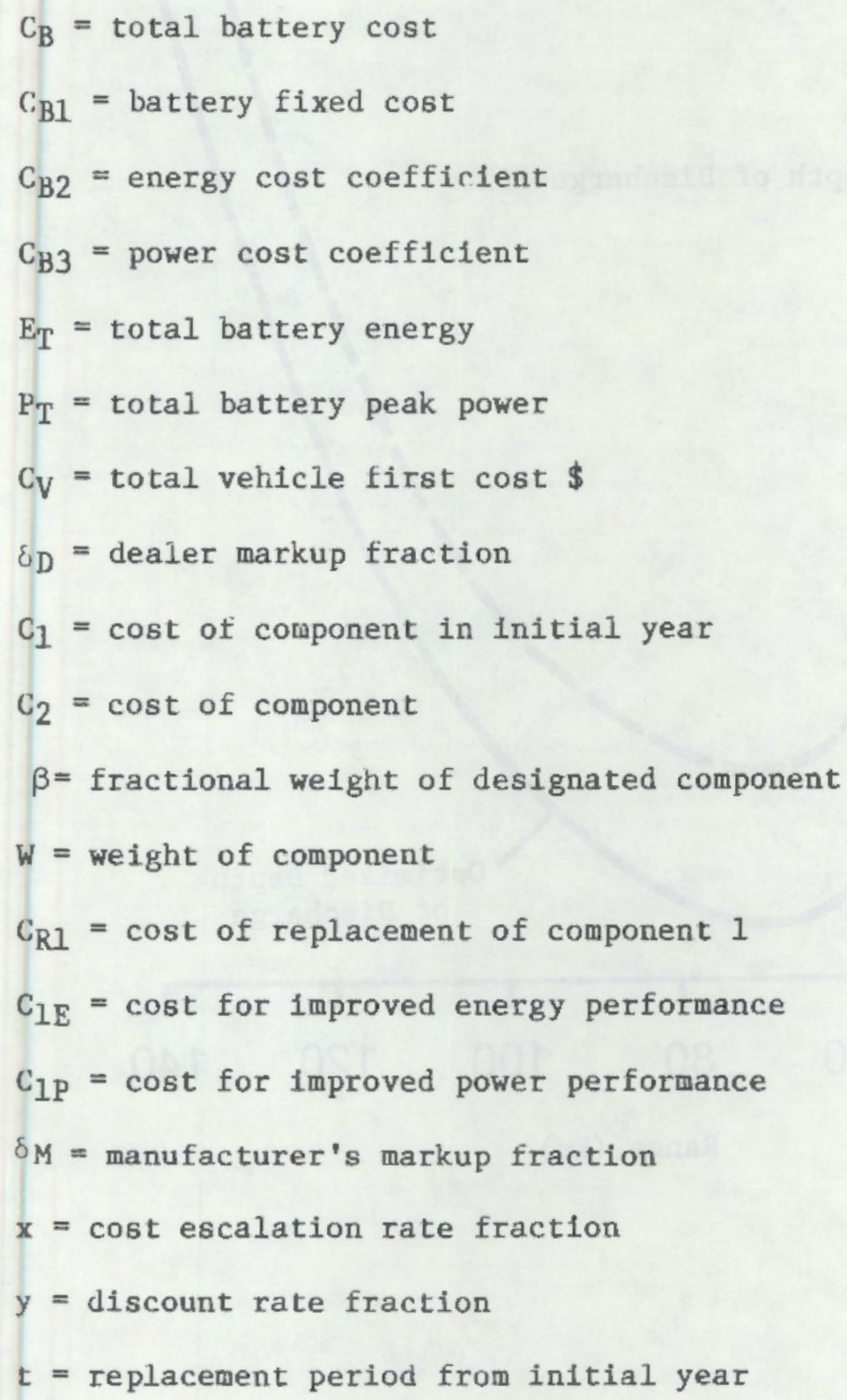




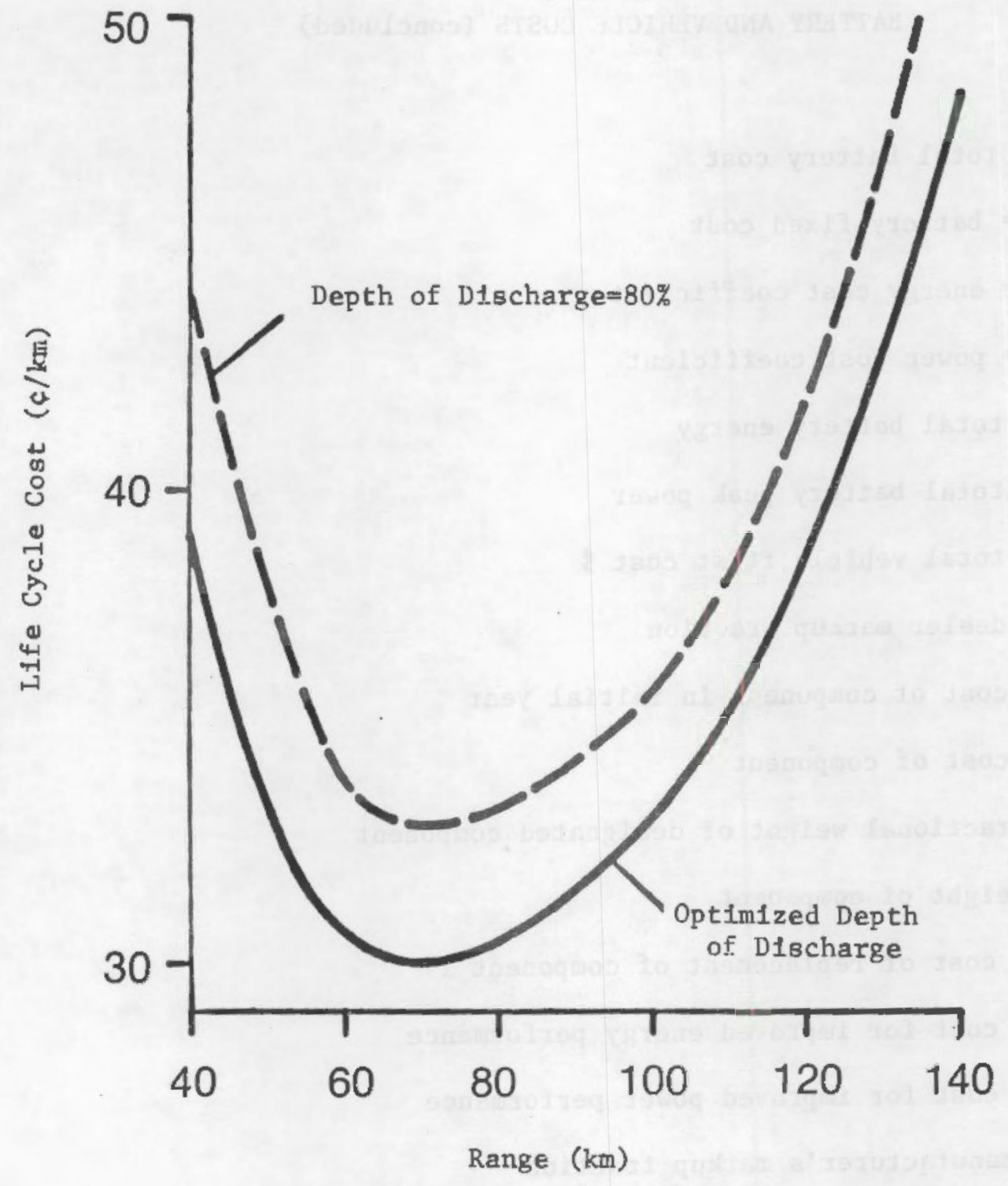

IMPACT OF RANGE AND DOD ON LIFE-CYCLE COST FIGURE 5 


\subsection{Battery Test Program and Facilities}

The EHV Battery Testing Working Task Force (Task Force) was established by the EHV and Energy Storage Technology (STOR)

Divisions of DOE in January 1983. The purpose of the Task Force is to review and make recommendations for Improvements of the DOE sponsored EV battery testing activities at national laboratories and contractors under a varlety of test conditions. (5) A major goal of the Task Force is to coordinate the testing methods used at the vartous laboratories and suggest standard test procedures and reporting practices.

A review was made of the $\mathrm{EV}$ battery testing programs of the organizations of the Task Force: Aerospace Corp., Argonne National Laboratory, Jet Propulsion Laboratory (JPL), Sandia National Laboratorles, and Tennessee Valley Authority (TVA). Generally, SNL evaluates battery systems that are in an early state of development for both EV and stationary storage applications. NBTL tests more mature technologies in application-specific tests. JPL and TVA perform system and on-road tests of englneering prototype units.

The Task Force reviewed the test program at NBTL. There was general concurrence with the tests betng conducted, however, several additional tests were proposed. The recommended procedure changes included:

- Ragone test - specific energy vs. specific power and maximum power based on thermal or safety limitations

- sustalned power test - $45 \mathrm{~W} / \mathrm{kg}$ discharge 15 repeated at various states-of-charge leading to the determination of the depth-of-discharge which supports a six-minute discharge

- effect of age on Ragone characteristics, driving cycle, and self-discharge characteristics

Another concern of the Task Force is the 1dentification of a stmplifled composite driving-cycle battery-life test. The Federal Urban Driving Schedule (FUDS) cycle was selected as the starting point. The simplifications, based on JPL EV modellng codes, consisted malnly of constructing constsnt power segments from the detalled FUDS structure and shortening the basic cycle to about three minutes. In all cases, the primary features of the modified cycle tests were within 10 percent of the original, based on a statistical comparison. 
NBTL, In cooperation with the EHV Battery Testing Task Force, has conducted an evaluation of the sultability of various proposed versions of FUDS as a standard for testing batterles. According to F. Hornstra, et. al., the distingulshing characteristics of FUDS are 1ts long cycling time $(0.38 \mathrm{~h}-12 \mathrm{~km}$ per cycle), its low average velocity $(\sim 32 \mathrm{~km} / \mathrm{h})$, and high acceleration requirements. (5) When applied to ETV-1, with vehicle current and voltage constraints Ignored, the battery requirements are characterlzed by high peak power ( $90 \mathrm{~W} / \mathrm{kg}$ requiring currents approaching $900 \mathrm{~A}$ ) and low average power $(10 \mathrm{~W} / \mathrm{kg})$. Batterles operated under these conditions achteved ranges comparable to those achieved with the SAE J227 aD schedule whlch has peak power requirements of $\sim 47 \mathrm{~W} / \mathrm{kg}$, an average power requirement of $\sim 15 \mathrm{~W} / \mathrm{kg}$, and an average velocity of $\sim 48 \mathrm{~km} / \mathrm{h}$. Table 7 gives a comparative summary of the test profiles of two versions of FUDS and the SAE J227aD urban driving schedule.

Following the development of the test cycle, it is planned to disseminate the recommended procedures to organizations outside of the Task Force laboratorles.

The testing programs of batteries for electric vehicles and stationary energy storage are conducted at NBTL and SNL.

The NBTL facillties and the results of some of the tests conducted have been described in earlier status reports, references 1-4. Batteries developed under the DOE programs and by private industry are tested at the NBTL facilities. Included are batteries for EV's and EHV's, electric utility load leveling, and solar energy storage. (5)

The facility at NBTL has space for the simultaneous testing of 76 Independently operated batterles under various environmental conditions and over a wide range of voltages and currents. The NBTL has four major components:

- the control room and wain test area where amblent and elevated temperature testing are conducted

- the environmental annex, for low temperature and zinc/halogen battery testing

- the Battery Components Technology (BCT) Laboratory, where special instrumentation and software are 1nstalled to allow systematic parametric variation and optimization and other studies

- the high temperature test area which was recently added to test 11 thlum/sulfur and sodium/sulfur cells 
I'ABLE 7

COMPAKISON OE DRIVING CYCLES OF VEHICLE TEST PROFILES

PAKANETER

I. Time/Cycle

2. Range/Cycle (mi)

3. Average Velocity (mph)

4. Spectfic Power Requirements $(w / k g)$
PROFILE

\begin{tabular}{|c|c|c|}
\hline FUDS* & $\begin{array}{c}\text { FUDS } \\
\text { CLAMPED** }\end{array}$ & SAE J227aD** \\
\hline $1371 \mathrm{~s} ; 0.38 \mathrm{~h}$ & same & $121 s ; 0.034 \mathrm{~h}$ \\
\hline 7.45 & $\sim$ same & 0.94 \\
\hline 20 & -same & -30 \\
\hline 9.9 & $\begin{array}{l}9.7 \\
71 \text { to } 58\end{array}$ & $\begin{array}{l}14.9 \\
48\end{array}$ \\
\hline
\end{tabular}

5. Energy/Mile (Wh/mi)
A. Energy Consumption
B. Regenerative Braking (Keturned to Battery)

$56 \stackrel{241}{=23 \%}$ 263

$54=22 \% \quad 56=23 \% \quad 56=21 \%$

6. Achieved Kange
A. ISOA Lead-Acid
B. $\mathrm{Fe} / \mathrm{NiO}(\mathrm{OH})$
$68 \pm 7.5$
$83 \pm 7.5$
$104 \pm 7.5$
$73+1$
N.A.
$95 \pm 1$

(Vehicle $=$ Improved ETV-1 with $488 \mathrm{~kg}$ of Batteries)

\footnotetext{
*Applied as if vehicle had no current or voltage limitations, i.e., currents up to $900 \mathrm{~A}$ and voltages down to $1 \mathrm{~V} / \mathrm{cell}$ average were allowed to occur. * ${ }^{\prime} I E T V-1$ compatable (currents less than $400 \mathrm{~A}$ and voItages greater than

$\mathrm{I} .3 \mathrm{~V} / \mathrm{ce} \mathrm{Il}$ average were maintained (Tests conducted at NBTL-ANL)

Reference 5 (Barber)
} 
Over 1000 cells have been evaluated at NBTL. Most of these have been as 3 to 6 cell modules, but batterles of up to 140 cells have been included. Performance-characterization assessments are conducted under a series of charge/discharge cycles with constant current, constant power, peak power, and computer simulated dynamic load profile conditions. Charging algorlthms are provided to accommodate the battery under test. Special studles are conducted in the BCT laboratory to explore and opt1mize charge procedures, to 1nvestigate the impact of unlque load demands on battery performance, and to analyze the thermal management requirements of battery systems.

Scaling and normalization techniques developed and practiced at NBTL permit full-sized battery performance to be projected on the basis of 3 to 6 cell modules. Larger units are tested as the apecific battery technology matures.

The mapping of the battery specific energy as a function of the spectfic power at which 1t is discharged (Ragone plot) is one of the most useful of the EV battery tests performed. Figure 6 depicts the Ragone plots obtalned for varlous aqueous moblle-batterles tested. All of the batterles included, except for the EV-106 lead-ac1d golfcart and the Delco Remy zinc/nickel-oxide batterles, represent technology developed under the DOE program. Test results, other than the Ragone plots, are included In the discussions of the status of specific battery systems.

The goal of the battery tests at SNL $1 \mathrm{~s}$ to evaluate their operation under a variety of conditions and to determine electrochemical performance, efficlency, and 11fe. Theae data are to be used to direct the emphasis in the battery research and development efforts. The SNL test project is composed of two efforts. The first consists of laboratory bench scale testing of small, prototype cells and batterles. These include lead-actd, $z$ inc/bromine $\left(\mathrm{Zn} / \mathrm{Br}_{2}\right)$, chromous/ferrlc redox $\left(\mathrm{Cr}^{+2} / \mathrm{Fe}^{+3}\right)$, zinc/ferricyandde Ion $\left(\mathrm{Zn} / \mathrm{Fe}(\mathrm{CN})_{6}^{-3}\right)$, hydrogen/nickel oxlde $\left(\mathrm{H}_{2} / \mathrm{N} 1 \mathrm{O}(\mathrm{OH})\right)$, and cadmium/n1ckel oxide $(\mathrm{Cd} / \mathrm{N} 10(\mathrm{OH}))$. These cells and batterles have been evaluated under simulated solar application tests and parametric test plans. The second part involves testing batterlea under fleld test conditions representative of photovolta1c and wind systems, either utillty connected or in the stand-alone mode. Lead-acid batterles have been used to resolve test control and data acquisition systems. As in the case of the NBTL testing activities, the avaliable results are reviewed in the sections on the respective battery technologies. 


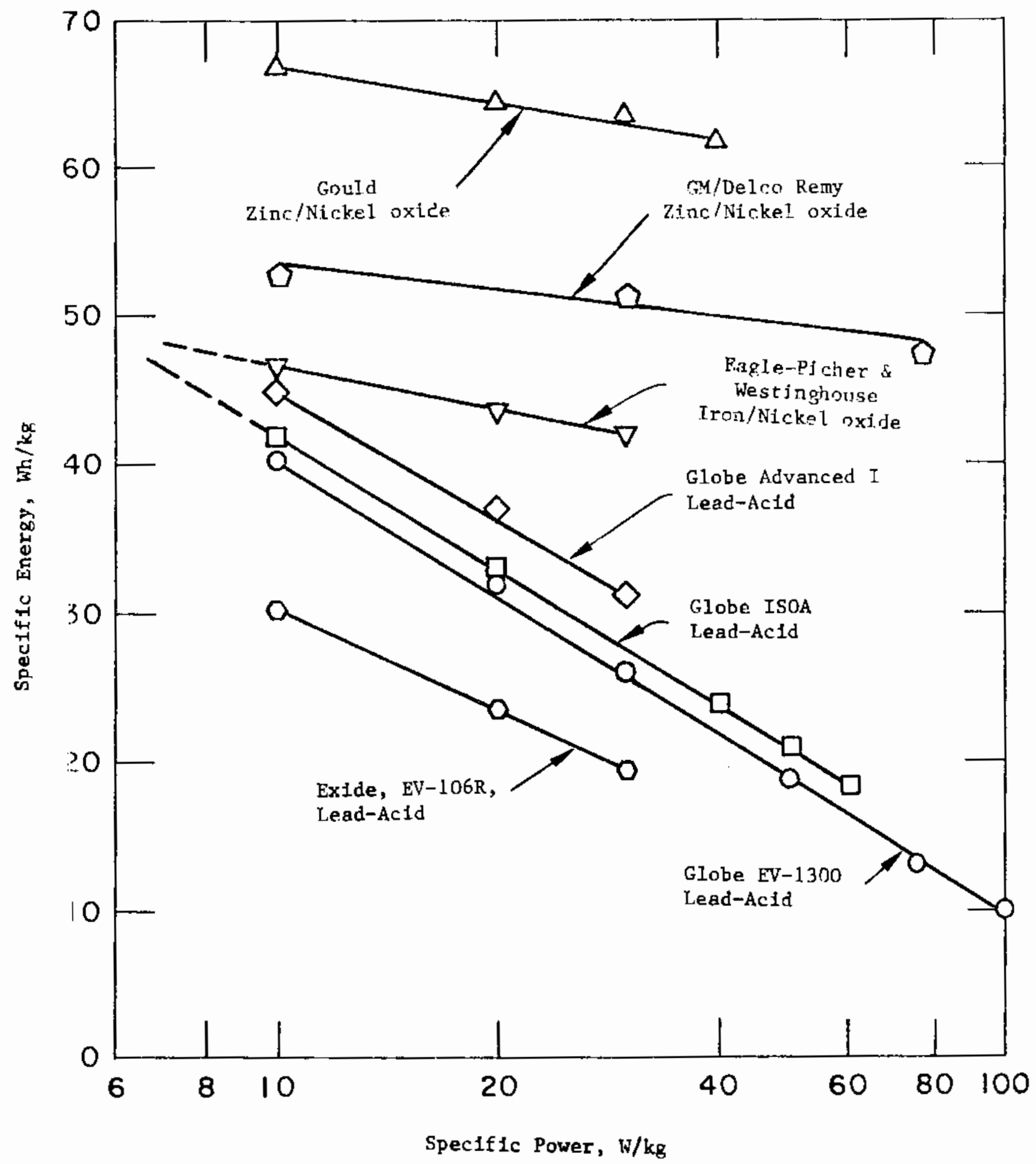

NBTL DEAIVED RAGONE PLOTS FOR AQUEOUS MOBILE BATTERIES FIGUAE 6 


\subsection{Technology Analysis and Transfer}

Technology analysis is being conducted by the Pacific Northwest Laboratory (PNL). The analyses are to assist the Energy Storage Technologies (EST) evaluations of programs, program information management, and system technology characterizations and assessments. The recently initiated efforts at PNL include several planning and support tasks. Included among these efforts are:

- the statistical analysis of battery fallures

- the evaluation of the status of emerging technologies

- the development of R\&D program evaluation techniques to support DOE headquarters

- the description of techntcal, economic, and environmental aspects of selected storage systems

- the automation of the work planning system for EST

- the assistance of technology transfer of EST funded research

The statistical analysis of battery failures is to develop analytical methods and the capability of:

- Identifying preferted multi-cell module test configurations

- evaluating the potential battery performance and risks before actual testing

The approach of PNL is to develop a model based on past battery failure observations and analyses. The model is then to be adapted to include failure data on the $\mathrm{Na} / \mathrm{S}$ battery. The results are to be validated by comparison of the simulated failure model with actual battery experience.

Part of the PNL support effort is an analysis of the patent 1iterature for the $\mathrm{Na} / \mathrm{S}$ battery. This should be of value in the analysis of the progress in the transferring of this technology.

BECC-6 included a study of a general electrochemical energy technology transfer plan and a summary of the transfer of technical advances in lead-acid battery technology resulting from the DOE program to lead-acld battery practice. 
The DOE defines technology transfer as "the transformation of research and development into processes, products and services that can be applied to state and local governments and private sector needs." This suggests a sequential flow of technology from a research result to an end-use application or user.

The ECS technology transfer effort, according to Regis Schelthauer et. al., Jaycor, is intended to integrate end-use technical and economic requirements with institutional issues that may Impede or factlitate the use of electrochem1cal energy storage technologles by the private sector. (5) The effort has five major tasks:

- defining selected markets for electrochemical energy storage for load-leveling

- charactertzing and 1dent1fying participants in electrochemical energy storage product development and commerclalization

- documenting and analyzing selected previous efforts to transfer DOE-sponsored electrochemical energy storage technology to the priyate sector

- Identify fng and analyzing institutional 1ssues which may affect the technology transfer of ECS-sponsored research and development

- developing a set of technology transfer recommendations tallored to specific end-use markets.

A preliminary characterization of the commercial and industrial economic sectors have identifled several potentially receptive markets for load-levellng batter1es. These have load shapes that complement customer-side-of-the-meter storage. Examples Include: grocerles, department stores, hospitals, new car dealers, and lumber, stone, and glass producers. Institutional characteristics for each market have been Identifled and potentlal market size calculated. The battery application matrix derlved by Scheithauer is shown in Table 8 . Several mot1ve applications have also been 1dentifled: industrial fork lifts, alrline ground support vehicles, lawn mowers, golf carts, and fleet EV's.

The results of a 1983 survey of eight domestic alrlines showed an Increase in the use of ground support EV's, from 5 percent in 1981 to 11 percent in ' 83 . The alrline respondents projected that by 1990 fifty percent of their 9,000 ground support vehicles will be battery powered. The respondents represented 26 percent of the 
TABLE 8

BATTERY APPLICATION MATRIX (EXAMPLE)

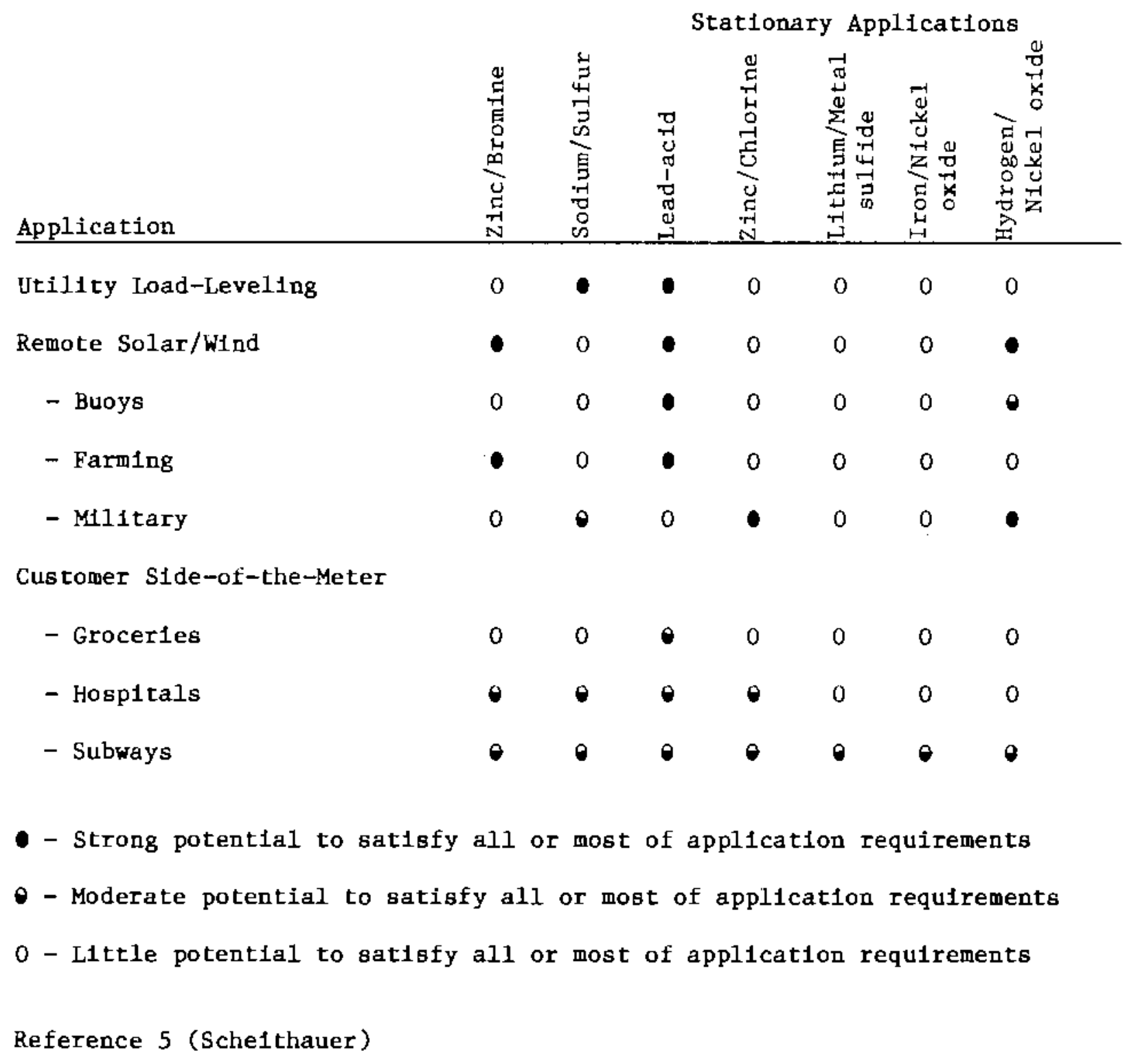


potential market. Eastern Airlines was reported as clatming the following:

- battery-powered vehicles cost $\$ 137,000$ less than their Diesel counterpart

- energy costs are lower per pushout, \$0.21 for battery charging vs $\$ 2.41$ for Dlesel fuel

The pushout tractor is a 62,000 pound $(23,130 \mathrm{~kg})$ vehicle, including batteries. It has $2-40 \mathrm{hp}$ electric motors, a top speed of $7 \mathrm{mph}(11.2 \mathrm{~km} / \mathrm{h})$, and is capable of pushing a 425,000 pound $(158,500 \mathrm{~kg})$ alrcraft up a two percent grade for 600 feet $(182 \mathrm{~m})$. The battery requirements are being met with SOA lead-acid batteries with the following specifications:

- 2-600 Ah batterles

- 64 cell batterles with 19 plates/cell

- total battery welght of 12,000 pounds (4475 kg)

The status of the varlous battery technologles has also been reviewed. The results of the analysis of the sodium/sulfur battery were detailed and specific conclusions on this battery technology are included in Section 6.3.1.

The study is also focusing on institutional factors which are likely to be lmportant to the acceptance of a technology by the private sector. Included among the issues identified are:

- required return on investment

- capital avaflability and cost

- Insurabil1ty

- ability to handle explosive and hazardous materials

- safety and environmental control requirements

- app1fcabilfty of use-restrictions

- potential for bullding and code regtrictions

To aid in making specific recomendations for technology transfer, case studies of previously successful transfers of ECS-sponsored technology to the private sector are being analyzed. These transfers have been described in Sections 1.1 and 1.2. 
Schelthauer also discussed the advantages, d1sadvantages, and appropriate situation for seven different technology transfer mechanisms. These mechanisms, together with the battery requirements for the various potential end uses, will be synthesized into a set of technology transfer recommendations.

Walsh, ANL, conducted a case study of the transfer of lead-actd battery advances resulting from the research supported by DOE under the technical direction of the ECS program. Most of the related research and development was under the technical management of ANL. The study 1ncluded:

- documentation of technical advances

- examination of relationship of federal/private R\&D efforts

- description of private-sector outcomes

- analysis of the approprlate federal role

Among the positive impacts of the DOE lead-acid battery research and development program is an anticlpated increase in private sector research and development following the phase out of DOE funding. Prlor to the federal program, lead-acid battery research and development was relatively dormant. were:

Among the technology advances regulting from DOE sponsorship

- Improvement of specific energy by $30-50$ percent

- advances in cycle life

- Improvements in auxillaries and operating procedures (e.g., wand watering system, control instrumentation)

Specific commercial products that have resulted include:

- EV batterles are offered for sale

- batterles for fork-lift, golf cart, and other traction applications contain DOE-developed technology

- batteries for starting-1ighting-1gnition contalalng DOE program advances in positive electrode technology are being planned 
Walsh has concluded that the program has resulted in a greatly improved national conpetitive position in lead-acid batteries.

Furthernore, the USA now appears to have the best lead-acid battery technology in the world. However, there remalns the potential for further advances in lead-acid battery technology involving longrange high-risk research and development. Specifically, this would involve high-rate lead-acid batterles capable of $50-60 \mathrm{Wh} / \mathrm{kg}$ and could include b1polar battery construction. Walsh is of the opinion that this type of effort is essential to maintaining the USA front position in lead-acid battery technology. 


\subsection{AQUEOUS NON-FLOW BATTERIES}

Th1s section on aqueous batterles 1s limited to those couples In which all negative and positive reactants are included in the electrodes and are not added to the cell during discharge. These batterles have been discussed in earller status reports, references 1-4, as part of the Near-Term Battery Program. Included are the lead-ac1d, 1ron/nicke1-oxide, and zinc/n1ckel-oxide couples. The present ECS effort on these battery systems is limited to basic and applied research to establish the basis for overcoming some of the shortcomings 1n these systems as defined by battery system scale-up and EV demonstrations. The definition of required 1mprovements, based on simulated and in-vehicle testing, is part of the Aqueous Mob1le Battery (AMB) project of the EHV program. The AMB project is under the technical monitorship of ANL.

Efforts are also continuing on selected aspects of the use of lead-actd batterles in stationary storage for load-leveling in electric utflity systems and for stand-alone and grid-connected solar systems.

This section will up-date the results of the developmental and testing activities reported since status report IV, reference 4, and the results of continuing research and testing. Some of the earlier advances in lead-ac1d battery technology resulting from the DOE program were noted In Chapters 1 and 2 .

\subsection{Lead-Ac1d Batteries}

The lead-acid battery, because of its commerclal avallability and high state-of-development, is continuing to be used in system evaluations for both stationary and mobile battery applications. It is the reference system for establishing required battery system Improvements, both technical and economic, and for establishing whether or not 1mproved or advanced battery technologies w11l meet the established goals. These goals for both stationary and mobile applications have been detafled in earlier status reports, references $1-4$.

The major reported R\&D effort on stationary lead-ac1d batterles has been the completion of the Exide development and testing of selected battery variables. The development of some of the technology involved was supported by the DOE program and others were commercially developed and wade avallable by manufacturers for testing by DOE. 


\subsubsection{Statlonary Lead-Acid Batteries}

The Exide investigations relating to stationary batteries for utility application have been detailed $1 \mathrm{n}$ a final report $(9)$ and included in the BECC-6 Extended Abstracts ${ }^{(5)}$. The overall goals of this progran are shown in Table 9. Three accelerated tests, detajled in reference 3 , were developed to establish a valid basis for extrapolating performance:

- continuous overcharging to test positive grid corrosion

- shallow cycling to test shedding of positive and negative active materials from plates

- deep cycling ( 80 percent DoD) at elevated temperature to test capacity loss during cycling, active material shedding, positive grid corrosion, cell case/cover materlals, and seals

The major results were:

- overcharge corrosion testing verffled that the lead-alloy and grid design selected for the positive should satisfy the life-cycle goal

- the active material shedding test gave evidence that a new additive for the positive active materlal would reduce shedding during shallow cycling

- the deep-cycling test Indicated that the equivalent of 6000 cycles at normal operating temperatures are achtevable

Baged on these results and Exide experlence with the design and production of large submarine batteries, a manufacturing cost study was conducted. It was concluded that mechanization of assembly processes might require substantially less new capltal investment if small battery dimensions could be used with automation similar to that developed for the production of SOA starting-lighting-ignition battertes. This approach promised an increased rate of production at competitive prices. The flnal decision was to develop a deepcycling cell in the same geometry and with the same manufacturing tooling required for stationary float-type batterles which are current1y being mass produced by Exide.

The selected battery design includes the following features:

- pasted flat-plate designs with the anticipation that plate wrapping of retainers and separation system could be automated 
TABLE 9

LEAD-ACID LOAD-LEVELING BATTERY GOALS

Goal

BEST Battery MWh

L1fe Stand, Yr Cycles ( $80 \%$ DoD)

Energy Efficlency, Turnaround \%

Energy Footprint $\mathrm{kWh} / \mathrm{m}^{2}$

Inttlal Battery Prlce, $\$ / \mathrm{kWh}$

Lead $25 \& / 1 b$

$58 d / 1 b$

Battery Rebulld Price $\%$ of Initial

Operating Temperature ${ }^{\circ} \mathrm{C}$

Cycle Discharge h

Recharge $h$

Depth \%

$5-h$ rate

Initial

State-ofThe-Art

$\begin{array}{rr}5 & 5 \\ 10 & 20 \\ 2,000 & 4,000 \\ 76-85 & 80 \\ 43-54 & 75 \\ & \\ 42-58 & 37-50 \\ 75-100 & 50-75 \\ 46-79 & 50 \\ & \\ 4-50 & 4-50 \\ 5 & 5 \\ 7-10 & 5-7 \\ 80 & 80\end{array}$

Advanced

Battery

Reference 9 (Chreitzberg) 
- cell cases and covers of Lexan $^{R}$ polycarbonate plastic were selected in sizes convenient for scaling-up from 5 to 35 plate cells

- terminal posts, straps, and plate grids were selected from available production designs and tooling

The cell development and testing reported in reference 9 has been continued under the support of SNL and Exide. Testing of competing 35-plate cell designs, inftlated under the DOE supported contract, has been continued at Exide. The test group is composed of four deslgn sets of two cells each. The major design parameters being examined are:

- positive active material (PAM) density, 4.0 and $3.2 \mathrm{~g} / \mathrm{cc}$

- ant1-shedding additive in low density PAM to permit Increase in utilization without fallure frow excesslve PAM shedding

- retalner system glass mats of slyver or random glass fibers with and without perforated polyvinyl chloride (PVC) sheets

- type of spacing between plates

- negative to positive active matertal ratio of 0.8 and 1.0

Cormon features to all cells are:

- 17 positive plates w1th long life $\mathrm{Pb}-\mathrm{Sb}$ alloy grid

- 18 negative plates with a $\mathrm{Pb}-\mathrm{Ca}$ alloy grid and high active materla1 density

- mIcroporous rubber separator

- $1.285 \mathrm{sp}$. gr. sulfurlc acid electrolyte

- one air-lift circulation pump in each cell

- polycarbonate jar and cover

The test cycle, after Inttial capacity bulid-up, consisted of 2-80 percent DoD cycies daily at the 5 hour rate to a minimum of $1.6 \mathrm{~V} / \mathrm{celll}$ at amblent temperature and without cell cooling. Cell electrolyte temperatures ranged from $34-44^{\circ} \mathrm{C}$. Once a month a capacity measur1ng discharge to 100 percent DoD, full charge plus an 
equalization charge, and cool-down perlod were carrled out. The number of cycles completed, as of 1 May 1984, was 1590, including the 80 percent and 100 percent DoD cycles.

Results of the cycling tests, as of 1 May 1984, 1ncluded:

- based on the projections from the accelerated cycling tests, cells tested at $40^{\circ} \mathrm{C}$ had reached 72 -percent of the cycling goal for this temperature

- the capacity of low PAM density plates remained 10 percent higher for 20 percent less active material than the high PAM density plates during the cycles conducted. Capacity increase with cycling was continuing as of 1 May 1984. PAM utilization in Ah/kg PAM was 40-45\% higher than in high density plates

The data indicated the possibility that the high PAM density plates could, in time, exceed the capacity of the low PAM density plates.

Three batteries (one $36 \mathrm{kWh}$ and two $18 \mathrm{kWh}$ ) of the final preprototype design were delivered for testing at NBTL. The key characterlstics of the $36 \mathrm{kWh}$ battery, as reported by NBTL, are given in Table 10. This battery was under tegt as of May 1984. The life-cycle tests are to be continued to failure.

Sealed lead-acid batteries are being tested at SNL for standalone and grid-connected solar systems. (5) Over thirty, 6 V, 100 Ah Gould and Eagle-Picher (EP) batteries have been tested with several continuing on test (May 1984). Table 11 summarlzes the results of these tests, Including tests on a C\&D flooded lead-acid battery. Cycle testing consists of both 80 percent DoD cycles and partial recharge cycles with test batterles operated between 80 and 20 percent DoD wlthout complete recharge. For the Gould batteries, tested for over 1000 cycles at the 5 -h rate, the fallure mode was typically positive grid corrosion. Failure modes are being determined on units that falled after approxlmately 500 cycles. Although the earller EP batterles had short cycle-lives, more recent untts show performance equal to Gould batterles. The C\&D flooded batterles also had performances comparable to the Gould batteries. The two types of test showed no differences in performance or iffe. (5)

\subsubsection{EV Lead-Acid Batterles}

The Globe Battery Division of Johnson Controls, Inc. (Globe) has deta1led 1ts efforts on the EV lead-acid battery for 
TABLE 10

NBI'L T'EST RESULTS OF EXIDE LOAD-LEVELING BATTERY

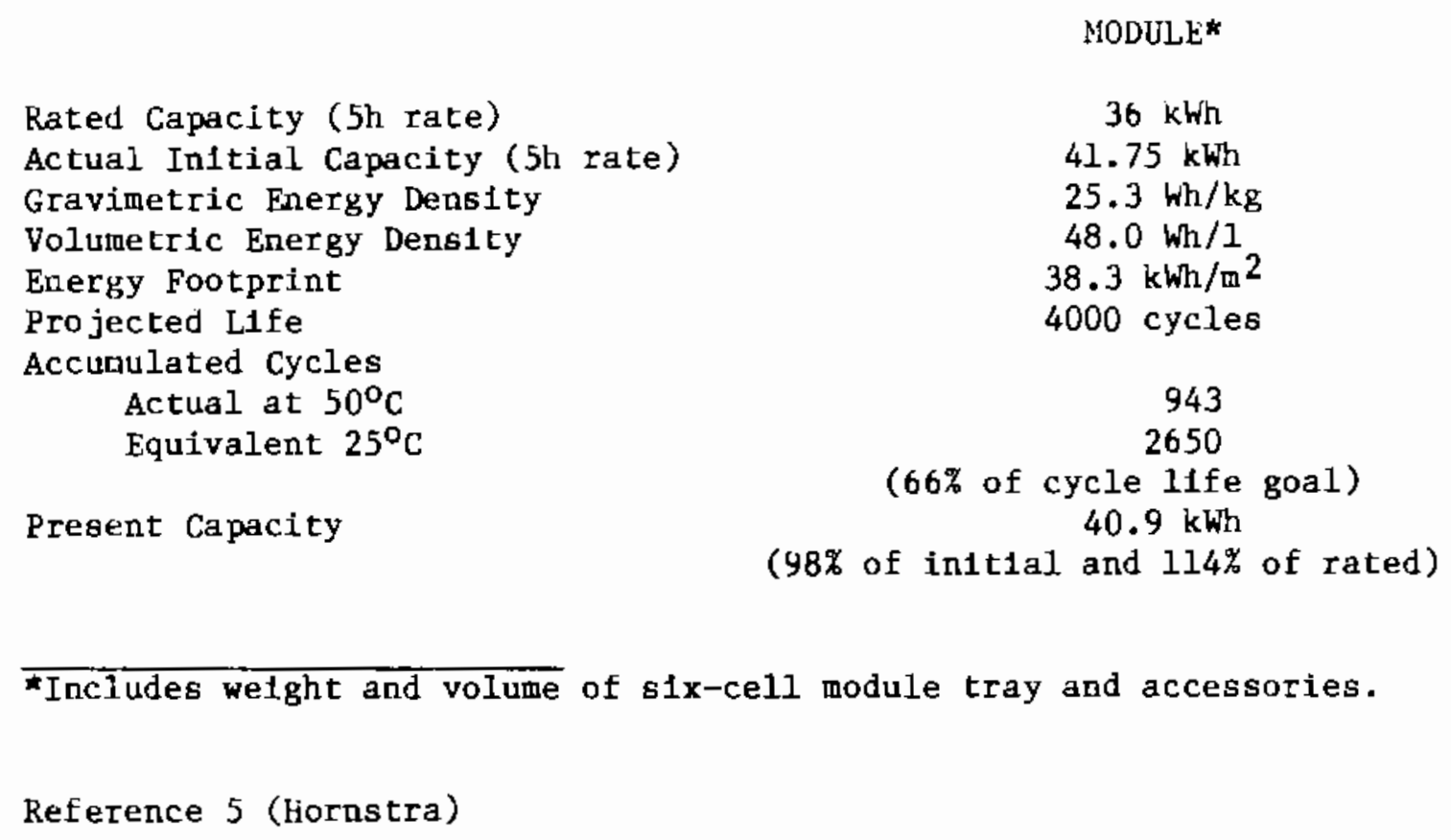


TABLE 11

SEALED LEAD-ACID BATTERY CYCLE TEST SUMMARY

\begin{tabular}{|c|c|c|c|c|}
\hline Manufacturer/Type & $\underline{I D}$ ㅂ & Test Mode & $\begin{array}{c}\text { Cycles } \\
\text { Completed }\end{array}$ & $\begin{array}{c}\begin{array}{r}\text { Percent of } \\
\text { Rated Capacity }\end{array} \\
\end{array}$ \\
\hline $\begin{array}{l}\text { Gould/Sealed Pb-Acid } \\
\text { Group } 2 \\
\text { (delivered } 4 / 81 \text { ) }\end{array}$ & $\begin{array}{l}137 \\
138 \\
139\end{array}$ & $\begin{array}{l}\text { DEEP } \\
\text { DPSOC H } \\
\text { DPSOC }\end{array}$ & $\begin{array}{r}972 \\
1336 \\
1002\end{array}$ & $\begin{array}{l}80^{\star} \\
80^{\star} \\
80^{\star}\end{array}$ \\
\hline $\begin{array}{l}\text { Group } 3 \\
\text { (delivered } 8 / 81 \text { ) }\end{array}$ & $\begin{array}{l}157 \\
158 \\
159\end{array}$ & $\begin{array}{l}\text { DEEP } \\
\text { DEEP H } \\
\text { DPSOC }\end{array}$ & $\begin{array}{l}898 \\
761 \\
850\end{array}$ & $\begin{array}{l}80^{\star} \\
80^{\star} \\
80^{\star}\end{array}$ \\
\hline $\begin{array}{l}\text { Group } 4 \\
\text { (delivered 11/81) }\end{array}$ & $\begin{array}{l}183 \\
184 \\
185\end{array}$ & $\begin{array}{l}\text { DEEP H } \\
\text { DPSOC } \\
\text { DEEP }\end{array}$ & $\begin{array}{l}886 \\
798 \\
729\end{array}$ & $\begin{array}{c}80 \star \\
(125)^{\star} \\
80^{\star}\end{array}$ \\
\hline $\begin{array}{l}\text { Group } 5 \\
\text { (dellvered } 3 / 82 \text { ) }\end{array}$ & $\begin{array}{l}196 \\
197 \\
198\end{array}$ & $\begin{array}{l}\text { DEEP } \\
\text { DPSOC H } \\
\text { DPSOC H }\end{array}$ & $\begin{array}{l}495 \\
394 \\
567\end{array}$ & $\begin{array}{l}80^{\star} \\
80^{\star} \\
80^{\star}\end{array}$ \\
\hline $\begin{array}{l}\text { Group } 6 \\
\text { (delivered } 3 / 83 \text { ) }\end{array}$ & $\begin{array}{l}331 \\
332 \\
333 \\
334\end{array}$ & $\begin{array}{l}\text { DPSOC-S } \\
\text { DPSOC-S } \\
\text { DPSOC-S } \\
\text { DPSOC-S }\end{array}$ & $\begin{array}{l}598 \\
390 \\
387 \\
385\end{array}$ & $\begin{array}{l}80^{\star} \\
80^{\star} \\
80^{\star} \\
80^{\star}\end{array}$ \\
\hline $\begin{array}{l}\text { Group } 7 \\
\text { (delivered 1/83) }\end{array}$ & $\begin{array}{l}311 \\
312 \\
313\end{array}$ & $\begin{array}{l}\text { DEEP } \\
\text { DPSOC } \\
\text { DPSOC H }\end{array}$ & $\begin{array}{l}789 \\
780 \\
932\end{array}$ & $\begin{array}{l}93 \\
72^{\star} \\
75^{\star}\end{array}$ \\
\hline $\begin{array}{l}\text { Group } 8 \\
\text { (delivered } 1 / 83 \text { ) }\end{array}$ & $\begin{array}{l}335 \\
336 \\
337\end{array}$ & $\begin{array}{l}\text { DEEP @ } 2.5 \mathrm{~V} \\
\text { DEEP } 2.6 \mathrm{~V} \\
\text { DEEP } 2.7 \mathrm{~V}\end{array}$ & $\begin{array}{l}856 \\
401 \\
306\end{array}$ & $\begin{array}{l}81 \\
80^{\star} \\
80^{\star}\end{array}$ \\
\hline $\begin{array}{l}\text { EP/Sealed Pb-Acid } \\
\text { (dellvered } 1 / 82 \text { ) }\end{array}$ & $\begin{array}{l}179 \\
180 \\
181 \\
182\end{array}$ & $\begin{array}{l}\text { DEEP H } \\
\text { DPSOC H } \\
\text { DEEP H } \\
\text { DPSOC H-S }\end{array}$ & $\begin{array}{r}944 \\
670 \\
919 \\
1141\end{array}$ & $\begin{array}{c}80 \star \\
79 \star \\
91 \\
106\end{array}$ \\
\hline C\&D/Flooded Pb-Acid & $\begin{array}{l}98 \\
99\end{array}$ & $\begin{array}{l}\text { DEEP } \\
\text { DPSOC }\end{array}$ & $\begin{array}{l}710 \\
931\end{array}$ & $\begin{array}{l}80^{\star} \\
80^{\star}\end{array}$ \\
\hline
\end{tabular}

$\overline{\star C y c l e ~ t e s t i n g ~ t e r m i n a t e d ~}$

(Date as of May 1, 1984)

Test Modes: DEEP - 80\% DoD d C/5 rate

DPSOC - Deep Partial State of Charge d C/5 Rate

$\mathrm{H}$ - Indicates horizontal plate orientation

-s - indicates serles test station configuration

Reference 5 (Butler) 
1982. (10) These results were partially covered in reference 4 and are expanded here based on the additional data available.

One objective of the Globe research effort is the improved utilization of the active material in the lead-acid battery. One approach has been the investigation of the effects of plate thickness on active material utilization. Three different positive electrode thicknesses were investigated at various current densities. A 20 percent improvement in the active naterial utilization was found when the electrode thickness was decreased 42 percent. Replacing an 11 electrode test cell with a 15 thin negative and positive electrode cell, the materlal utilization immediately after formulation was increased by approximately 25 percent. It was also shown that decreased positive paste density led $t$, the expected greater utillzation of active material.

Studies on the lead-plastic composite electrodes has continued. The formation efficiency of these electrodes has been found to be satisfactory. Deep-discharge cycling of test cells with the composite grids has been initiated.

Studies were conducted on the role of antimony, released by the positive grid during the cycling of the battery, on cell performance degradation. The cycling of an ISOA cell with $\mathrm{Pb}-\mathrm{Sb}$ positive grids showed that antimony accumulated in the negative plate and this was the cause of the marked decline in cell capacity. Lead microelectrode studies showed that decreased charge efficiency of the lead negative due to antimony could be suppressed by the presence of $20 \mathrm{ppm}$ of. Maracel1 C. Lignin. Further investigation is required to clarify the mechanism of the suppresston of the harmful effect of antimony on negative electrode charge efficiency. Tests were also conducted on the removal of antimony from the negative electrode as a function of the negative charging potential. It was shown that the antimony content of the negative plate was decreased with increasing charging potential relative to a reference electrode.

Cycling tests on 15 electrode test cells showed that ce11 cycle life was determined by the positive electrode. Plate integrity was extremely good in all cells. Furthermore, physical and microscopic examination showed the grid to be 1n good condition. Microscopic examination of the grid/active material interface indicated defects in this interface. It was also observed that the positive material was eastly dislodged. These observations suggest that the positive plate legradation is due to the weakening of the active material/ grid interaction. This observation was tested in electrodes with larger areas of active material between grid connections. The cells with the larger free active material areas showed more rapid capacity loss. 
Studies were conducted to test patent claims of the improved deep-discharge cycle life of lead-acid batteries lising bonding agents, hydroxyethyl methacrylate or polyacrylic acid with polytetrafluoroethylene (PTFE), in the positive plate. Following formation, the acetic acid content of the cell was $1100 \mu \mathrm{g} / \mathrm{ml}$ compared to $60 \mathrm{\mu g} / \mathrm{ml}$ in standard cells. The overall cycle-1ife performance of these cells was pourer than the standard cell and the patent cla1ms were not confirmed.

The effort to develop a monitoring system that accurately displays the percent state-of-charge of the battery pack at Globe has not been successful. The major difficulty was interference from the electric vehicle controller which prevented valid conclusions.

Thermal management of $\mathrm{EV}$ batteries has also been examined. During a $3 \mathrm{~h}$ discharge and $7 \mathrm{~h}$ charge ( 5 percent overcharge) of a battery module, temperature excurstons of $15-20^{\circ} \mathrm{C}$ were observed when the amblent temperature was $25^{\circ} \mathrm{C}$. The highest temperatures reached were between $40^{\circ}$ and $45^{\circ} \mathrm{C}$ in the center of the electrode stack. Forced alr convection on the sides of the module reduced the overall temperature excursion. The use of the Globe developed airpulse pump for acid circulation reduced the temperature rise and promoted uniform temperature distribution.

Effort was reported at Globe to replace the electronically controlled electrolyte circulation system by a pneumatic system. Th1s system was demonstrated to work but its rellabllity requires 1mprovement. It was projected that the pneumatic system will cost approximately one-elghth that of the current electronically controlled electrolyte clrculating system. Several Globe lead-acid modules with the electronic electrolyte c1rculating system have been submitted to NBTL for test1ng.

Earlier it was noted that the use of a watering wand decreased the watering time for lead-acld batterles. An alternative route to decreasing the watering problem is being investigated as part of the Technology Sultability Testing element. Ge1/cell ${ }^{R}$ (Globe) sealed lead-acld batterles are being studied. The temperature sensitivity of charge/discharge, cycle Iffe characteristics, and overall performance when subjected to urban driving conditions are being evaluated. Although the battery was initially developed for industrial applications, it is being tested as an EV battery because of its potential for reducing operating costs. The test program is to include fleld testing of approximately 40 vehicles starting in early FY 1985. 
Studies were conducted to assess the impact of temperature on the cycle life of Globe ISOA lead-acid modules. This assessment was made as guidance to the thermal control requirements for optimized performance and cycle life of EV batteries. In these tests, modules were discharged for a fixed relative number of $\mathrm{Ah}^{\top} \mathrm{s}$ ( 80 percent Dob, based on room temperature capacity measurements), independently of operating temperature, in order to simulate a vehicle with a temperature-independent fixed mission. Under these conditions, a marked decrease in cycle life was observed at temperatures of $15^{\circ} \mathrm{C}$ and $52^{\circ} \mathrm{C}$. optimum cycle life appeared to be achieved over a temperature range between $30^{\circ} \mathrm{C}$ and $44^{\circ} \mathrm{C}$.

A test program at the University of Alabama in Huntsville (UAH) was designed to assess the battery problems encountered when EV's are ojerated at various temperatures and to provide an engineering data yase for the elimination of these problems. Three different $96 \mathrm{~V}: \mathrm{V}$ lead-acld batterles were compared between the temperatures of $-15^{\circ} \mathrm{C}$ to $54^{\circ} \mathrm{C}$. (11) An attempt was made to correlate the performance observed with the design features of the batteries tested.

Varlous devices for electrolyte mixing to 1mprove active material utilization and cycle-life of lead-acid batteries have been designed and evaluated at UAH. (12) A simple low cost pump device, operated on pulsed air, that gave improved cell performance was developed.

Tests of the Globe EV batteries have been included in the NBTL program. Figure 6 is the result of the Ragone plots obtalned on lead-acid and other battertes tested at NBTL. The Globe Advanced I battery shows the advances made in the combined specific energy and specific power performance of lead-acld batteries.

Some of the achievements of the lead-acid battery program were noted by Streb and by Landgrebe (Sections 1.1 and 1.2). More specific achievements were summarlzed by K1rk:(5)

Characteristic

Specific Energy Wh/ $\mathrm{kg}$

Specific Power $\mathrm{w} / \mathrm{kg}$

Cycle Life cycles

$(80 \%$ DoD)
1977

32

92

250
Performance Achleved

43

104

560
Goal

104

800 


\subsection{Alkaline Batteries}

The major effort is on developing iron/nickel-oxide batteries for vehicles. There is no DOE supported developmental effort on the zinc/nickel-oxide battery. Testing of the commercially ieveloped Delco Remy zinc/nicke1-oxide battery is being conducted at NBTL. Research is being continued on the fundamental aspects of the iron, zinc, and nickel-axide electroces.

\subsubsection{Iron/N1ckel-0xide Batterles}

The 1ron/nickel-oxide battery program goals and 1982 objectives are given in Table 12 .

The 1ron/nickel-oxide battery efforts at Eagle-Picher (EP) are emphasizing the following:(13)

- process improvements for nickel-plaque development and its impregnation to increase the battery specific energy

- overall system 1mprovements to facllitate battery maintenance

- reduce and eliminate any potential ignition hazards in the battery

Plaque-substrate development has centered on a comparison of woven wire configurations vs, expanded metals. This included a comparison of pure nickel and nickel-plated products, A majority of the electrodes have been based on woven $0.18 \mathrm{~mm}$. diameter wire, $20 \mathrm{x}$ 20 mesh screens. The same wire was used for both the thin and thicker electrodes. Different woven wire and expanded metal configurations were analyzed in terms of cost, projected current carrying ability for the desired $3.4 \mathrm{~mm}$ thick electrode, and processability.

Concern was expressed with respect to nickel-plated substrates which are being acquired for further examination. The conductivity of the alternative substrates and their potential for contamination of the acidic impregnation bath and the cell environment are two concerns which are to be investigated.

The development of an advanced nickel plaque requires an incremental increase in thickness from 2.0 to $3.4 \mathrm{~mm}$. An 1ncrease in porosity from 80 percent to 85 percent is also desired. The improved plaque must have the capability of act1ve material impregnation to a loading of $1.6 \mathrm{~g} / \mathrm{cc}$. 
TABLE 12

IKON/NICKEL-OXIDE BAT'I'EKY PERFORMANCE GOALS

$\begin{array}{lll} & \text { FY-1986 Goals } & 1982 \text { objective } \\ & & \\ \text { Specific Energy (C/3 rate) } & 56 \mathrm{Wh} / \mathrm{kg} & 54 \mathrm{Wh} / \mathrm{kg} \\ \text { Volumetric Specifc Energy } & 120 \mathrm{Wh} / 1 & 115 \mathrm{Wh} / 1 \\ \text { Specific Power - Peak (30 sec.) } & 104 \mathrm{~W} / \mathrm{kg} & 104 \mathrm{~W} / \mathrm{kg} \\ \text { Duty Cycle - Discharge } & 2-4 \mathrm{hrs} & 2-4 \mathrm{hrs} \\ \quad \text { Charge } & 4-8 \mathrm{hrs} & 4-8 \mathrm{hrs} \\ \text { Energy Efficiency (Round trip) } & 70 \% & 65 \% \\ \begin{array}{l}\text { ObM Price (1981 } \$ \text { for 10,000, } \\ \text { 25 kWh batteries/yr) }\end{array} & \$ 70 / \mathrm{kWh} & \$ 150 / \mathrm{kWh} \\ \begin{array}{l}\text { Cycle Life (80\% DoD to 75\% } \\ \text { capacity) }\end{array} & 800 \mathrm{cycles} & 800 \mathrm{cycles}\end{array}$


Attempts have been made to develop a slurry 1mpregnation formulation capable of being applied to a $3.4 \mathrm{~mm}$ thlck plaque. No entirely satisfactory slurry was achieved, as of the report date. Plaque strengths varied from 660 to $1630 \mathrm{psi}(4.5-11.1 \mathrm{MPa}$ ). Modification of slurry formulations to include pore formers is being explored. Condtions for plaque drying and sinterting are also being investigated. The reported plates had average thicknesses of 2.0 to $2.7 \mathrm{~mm}$, porosities of 81.0 to 84.8 percent, and break strengths of 692 to $1035 \mathrm{psi}(4.7-7.1 \mathrm{MPa})$.

Groups of plate types were 1mpregnated using the step-current method, $\mathrm{pH}-2.4$, and $2.4 \mathrm{M}$ nicke1 nitrate. Various problems arose during impregnation. Blistering was the most significant. Various process modifications to eliminate blistering are being studied. Another problem encountered was plate bowing. This has been corrected by modifying the slurry application process. The studies have shown that the desired level of loading can be achieved. For the highest estimated capacity, an active material loading of $\mathbf{1 . 6}$ $\mathrm{gm} / \mathrm{cc}$ of plaque was selected for cell testing. A comparison of a lightly loaded and a more heavily loaded plaque, at cycle no. 90 in a test cell, showed the capacity advantage of heavy loading:

$\begin{array}{ccc}\begin{array}{c}\text { Plaque } \\ \text { Loading } \\ \text { g/cc }\end{array} & \begin{array}{c}\text { Utilization } \\ \text { Percent }\end{array} & \begin{array}{c}\text { Output } \\ \text { Ah }\end{array} \\ & & \\ 1.35 & 86 & 154 \\ 1.55 & 80 & 164\end{array}$

During the period reported in reference 13, experimental threecell modules were constructed and tested. Except for specific energy and cost the program achleved the objectives for 1982 .

The multi-cell watering system was modifled by the addition of a flow control device and the coupling of this device to the battery. This eliminated the non-uniformities. Active battery tests showed that the filling rate should be approximately one cell per minute. This requires a two foot $(61 \mathrm{~cm})$ head.

Attempts were made to develop a flame arrestor which would prevent the accidential ignition of the hydrogen and oxygen which form during charging. Catalytic hydrogen and oxygen devices and flame arrestors were tested but none were completely successful.

Cells that were tested at NBTL and had shown charge voltage deviations and self-discharge after 760 cycles were disassembled for visual inspection. The following observations were reported: 
- The positive plates were in good condition. There were some sinall blisters which probably hat only a small effect on performance.

- The negative plates showed evidence of corrosion, especially at the outer edges. The central portions were intact.

- All the positive plates showed growth in width and length of approximately 1.5 percent. The stability was great enough to project that they would have survived an additional 800 cycles.

- The separator appeared to be loaded with sludge. Although the folded edges of the separator had been split by positive plate growth, the separator had not lost its effectiveness.

Some of the above shortcomings had been recognized prior to the cell inspection and changes were made in later cell designs. These included larger sludge space and placing the separator around the negative instead of the positive electrode.

The overall Westinghouse approach to the iron/nickel-oxide battery was sumnarized in reference 4. Details of the investigation of various approaches taken to achieve low-cost batteries that could meet performance objectives are included in reference 14 .

Improvements in the processes for making the various components in order to meet program goals continued through 1982. Some emphasis was placed on the preparation of pasted positive plates. The pasting composition developed earlier, conslsting of a mixture of hydrated nlcke1 oxide, nickel carbonate, and hydrated cobalt oxide continued to be used. Varlous commerclally avallable hydrated nickel oxides have been evaluated for their effect on paste rheology, plate formation, and in cell performance. Evaluation of the best of these materials was continuing at the end of the report perlod. (14)

Various plating procedures, both electroless and electrolytic, were investigated for coating the positive grid. A combination of both methods was found to be most effective for the prevention of grid corrosion. Alternative separators to the Celanese $\mathrm{K} 501$ standard separator were also investlgated. Based on the tests conducted, an alternative separator was selected for full cell testing. However, this material is more expensive than the standard material. 
Reduction in battery weight and volume is another major 1mprovement objective of the Westinghouse program. An integrated five or six cell module to replace the single cells used in the modules under test can reduce the number of "heavy" cell walls. Other Improvements considered the use of through-the-wall connectors instead of top mounted terminals with cell interconnect cables, and internal ducting for electrolyte circulation.

Charge optimization is being investigated to increase cycle energy efficiency from 50-55 percent to the destred 70 percent. This efficlency was achleved by discharging only 67 percent of the nominai $\mathrm{C} / 3$ capacity and charging at constant current to 105 percent of the current discharged.

The testing of iron/nickel-oxide batteries has continued beyond that reported by Eagle-Picher and Westinghouse.(13)(14) The tests at NBTL have shown that the specific energy and cycle life of iron/ nickel-oxide batteries exceed those of lead-acid batteries. However, the iron/nickel-oxide batteries require a significant overcharge to achieve full capacity. Repeatable iron/nickel-oxide batcery operation was achieved over a wide range of overcharge levels (10-50 percent). Discharge capacity increased with the level of overcharge. An overcharge level of 25 percent was typically required to obtain the manufacturer's rated capacity for the modules tested. Discharge capacities in excess of the rated value were achieved with overcharges of more than 25 percent. The maximum capacity obtained was 114 percent of the rated value. The combination of iron/nickel-oxide battery capacity and efficiency can be optimized for a particular application by the selection of the overcharge level.

The overcharge level required to achieve 1ron/nickel-oxide battery rated capacity was shown to be dependent on the battery's initial DoD level. A 75 percent overcharge was needed to attain rated capacity from a 100 percent DoD condition. From DoD levels of 25,50 and 75 percent, overcharges of about 50 percent were required. The greatest ampere hour overcharge level was required for a 75 percent DoD and caused the greatest evolution of hydrogen and of water consumption.

The rate of self-discharge of 1ron/nickel-oxide batteries was observed to be directly related to the standtime after charging and the state-of-charge of the battery. The self-discharge rate decreased rapldly during elther stand-by or dischsrge. A four hour standtime, after a recharge to provide full capacity, resulted in a 5.5 percent loss in capacity. In contrast, a four hour standtime at a 20 percent DoD level resulted in no measurable loss in capacity. 
The NBTL Ragone curve for the iron/nickel-oxide battery, Figure 6 , showed a higher specific energy at a given specific power than the lead-acid batteries tested.

Kirk summarized the advances made in the 1ron/ntckel-oxide battery under the DOE program:(5)

Characteristic

Spectfic Energy Wh/kg

Specj.fic Power $\mathrm{W} / \mathrm{kg}$

Cycle Life

(80\% DoD)
Performance

1977

86

510
Achleved

Goal

$$
48
$$

102

930

800

\subsubsection{Overview of Iron/N1cke1-oxide Battery Status}

The potential for long cycle-11fe, 800 or more cycles, for this cell is well established. Its major performance deficlency is its low energy efficiency. Th1s is largely due to the requirement of a high overcharge to restore the battery capacity.

Eagle-Picher has observed sludge formation during recycling. The probability of shorting due to the sludge was decreased by increasing the dead-space in the cell bottom. EP has also addressed the problem of the hazard due to hydrogen and oxygen accumulation, in part, related to the high overcharge requirement but which also can occur during the self-dlscharge after charging. Overcharging also leads to the need for a watering capability for large batteries such as those required for EV's. Westinghouse also recognizes the need to 1mprove the safety, performance, and rellability of the electrolyte management system. The need for malntenance free cells has also been noted by Westinghouse.

The achievability of the cost objectives for the 1ron/ nickel-oxlde battery, in spite of projections, needs to be better established. The Westinghouse approach to lower cost grids and pasted positive plates and lower cost cell and battery assemblies are targeted toward this need.

A fundamental concern is whether or not the high overcharge requirement for the iron/nickel-oxlde battery is inherent to the cell electrochemistry or 1 s in part due to electrode structure. This overcharge requirement limits the cycle efficiency, increases the 11fetime cost, and contributes to the hazard potential of the Iron/nickel-oxide battery. 


\subsubsection{2inc/Nickel-0xide Batteries}

The decision to discontinue the DOE support for the development of the zinc/nickel-oxide battery was reported in reference 4. That report included a summary of the status of the various $\mathrm{Zn} / \mathrm{N} 10(\mathrm{OH})$ battery development programs as of the t1me of their conclusion. The only $\mathrm{Zn} / \mathrm{NiO}(\mathrm{OH})$ battery investigation during 1983 and ear1y 1984 was the earlier noted NBTL testing of the privately developed DelcoRemy battery. The Ragone plot for the Delco-Remy battery is included in Figure 6 . Tests of this battery are continuing at NBTL to obtain additional information on cycle-life and other performance characteristics.

\subsubsection{Alkaline Battery Research}

The research on the alkaline battery electrode reactions, electrolyte, and separators is being continued as guidance to improved material selection, electrode composition, and electrode construction. These studies include electrolyte and electrode thermodynamics, electrode kinetics and mechanism, and zinc-ion transport through separators.

Earlier results of the study under Digby D. Macdonald on the thermodynamic framework for estimating the characteristics of alkaline battery electrolytes and the electrode reactions, were included in reference 4 . The completed efforts have been reported and represent an extension of the earlier summarized calculations of electrolyte thermodynamic properties and preparation of $\mathrm{pH}$-potential diagrams. (15) The thermodynamic data has been used to calculate reversible cell potentlals for a number of battery systems; these calculations assume well defined electrode reactions. The calculated reversible cell potentials were compared with observed cell voltages to compute the voltage efflclencles for various alkaline batterles. Included here are the results of metal/a1r and hydrogen/ nicke1-oxide couples which are to be reviewed in Chapter 4.0.

The calculated cell voltages varled w1th the concentration of alkali metal hydroxide and temperature. These varlations can be summarized in four groups:

- Al/a1r, $\mathrm{Zn} / \mathrm{a} 1 \mathrm{r}$, and $\mathrm{Zn} / \mathrm{NiO}(\mathrm{OH})$ - the cell potent1al increased with alkali concentration but decreased with an Increase in temperature

- L1/a1r and to a lesser extent Fe/air - the cell potentla1 decreased with alkali concentration but increased with an Increase in temperature 
- $\mathrm{Fe} / \mathrm{NiO}(\mathrm{OH})$ - the cell potential decreased with an increase in alkali concentration or an increase in temperature

$\mathrm{H}_{2} / \mathrm{NiO}(\mathrm{OH})$ - the cell potential is independent of concentration but decreases with temperatuce

The efficiencies of $\mathrm{H}_{2} / \mathrm{NiO}(\mathrm{OH}), \mathrm{Fe} / \mathrm{NiO}(\mathrm{OH})$, and $\mathrm{Zn} / \mathrm{NiO}(\mathrm{OH})$ test cells were between 90 and 100 percent. The high efficlencies imply that, at least on open circuit, there is little, if any, contribition from parasitic redox couples to the cell potentials for the above couples. The efflclency of the Fe/air test cell was relatively low ( 72 percent). This may have been determined by the nature of the redox couple at the alr electrode.

The above reported estimates are limited in accuracy because of the limitations of the approximation methods used to calculate the therrodynamic quantities required.

An experimental program has been eatablished to el1minate the uncertalnities of the above calculations. The uncertalnities include:

- the stolchlometric mean molal activity coefficient

- the Ion-assoctation constant

- the ionic product of water

To obtaln more accurate data, equilibrium potentials are to be measured in an electrochemical cell. The cell arrangement permits the simultaneous measurement of equilibrium potentials for three different cells. Two of the cells give concentration-cell potentials relative to $\mathrm{KOH}(1 \mathrm{~mol} / \mathrm{kg})$, and glve data on the electrode/ electrolyte properties. The third potential measurement enables the determination of water activity in the test alkali solution. (5)

\subsubsection{Iron Electrode Research}

Investigations have also been conducted on the chemical and electrochemical reactions at the various anodes and cathodes of alkallne cells. M.C.H. McKubre has used potentiodynamic sweep voltammetry and coulometry, rotating disc, and AC impedance measurements for studying anodic and cathodic reactions of alkallne battery active material.(16) The 1mpedance measurements and the1r interpretation were sumarized $1 \mathrm{n}$ references 3 and 4 .

The measurements have led McKubre to postulate a mechanism for the formation and discharge of an oxide f1Im on tron via a number of dissolved intermediate species. The thermodynamically favored 
reaction paths for the iron charge and discharge reactions at high and low temperatures have been derived from the dynamic electrochemical measurements. These favored reaction paths, together with the 1mpedance measurements, were used to propose a mechanism as a working hypothesis for future investigations. Some of the features of the mechanism 1nclude different pathways for the oxidation and reduction reactions as a function of temperature. $\mathrm{FeO}_{2}^{-}$is an intermediate species at low temperature whereas $\mathrm{HFe}_{\overline{2}}{ }_{2}$ is a h1gh temperature interwediate. The evidence indicates that the oxidation and reduction of 1ron proceed via the formation and discharge of an oxide film and involve a number of dissolved species. The exchange current at zero charge, $1_{0}$, showed that the kinetic constraints for the charge/discharge process decrease with increasing temperature. However, the principal kinetic 11mitations of charge and discharge originate within the oxide film and not with charge transfer at the interface. (16) Although the measurements were made in $\mathrm{NaOH}$, the general conclusions are considered to be applicable to $\mathrm{KOH}$.

D.S. Poa, et. al., have also invest1gated the mechanism and kinetics of 1ron dissolution reactions but used $\mathrm{KOH}$ as the electrolyte.(17) Both cyclic voltammetry and rotating ring-disc electrode (RRDE) techniques were used. The measurements were made in 0.5 to $10.0 \mathrm{M} \mathrm{KOH}$ with and without additives.

The RRDE experiments in 5 to $7.5 \mathrm{M} \mathrm{KOH}$ showed that the reversibility of the electrode is relatively higher at these concentrations, and the coulombic inefficlency and loss of reactant relatively lower during both charge and discharge, than in lower alkali concentrations. More concentrated electrolytes $(8-10 \mathrm{M})$ Indicated a greater probabllitiy of efficiency loss due to oxidative dissolution and the Increased formation of solid film products under anodic conditions. These factors may make the iron electrode less reversible in the high alkall concentration electrolytes.

Poa and coworkers also 1nvestfgated the effect of additives, such as $\mathrm{K}_{2} \mathrm{~S}, \mathrm{~L} 1 \mathrm{OH}$, and $\mathrm{FeO}$, on the behavior of the 1ron electrode. The results were interpreted as follows:

- $\mathrm{K}_{2} \mathrm{~S}$ - the optimum concentration of $\mathrm{K}_{2} \mathrm{~S}$ improves the reversibility of the 1ron electrode during charge and discharge cycling. $\mathrm{K}_{2} \mathrm{~S}$ can 1mprove the high-rate discharge performance and Increase the hydrogen overvoltage of the iron electrode

- LiOH - the RRDE measurements Indicated that L1OH decreases the extent of oxidation of $\mathrm{Fe}$ to valence states higher than 2, may 1mprove the $\mathrm{Fe}$ electrode reverstbility, and significantly reduces the formation of solid film products 
- Feo - the effect of Feo was interpreted as Indicating a decrease in solid-film product formation, the possible increase in soluble $\mathrm{Fe}(\mathrm{III})$ species, and increase in the hydrogen overvoltage

\subsubsection{Zinc Electrode Research}

The 11mited reversibility of the zinc electrode was the primary cause for discontinuing the development of the $\mathrm{Zn} / \mathrm{NiO}(\mathrm{OH})$ battery. The observed effects leading to the low cycle life of this battery are zinc dendrite formation, change in the shape of the active zinc area, zinc densification, and loss of zinc from the negative electrode. Several research efforts have been undertaken under the LBL TBR activity to give guidance for increasing the cycle life of the zinc electrode.

Elton J. Calins and assoclates at LBL are investigating factors affecting the cycle life of the alkaline zinc electrode. (5) (18) Earller studies, reference 4, had shown that pulsed-charging at low peak current density and 1 ow charge per pulse gave the best cycling results. Further studies have included the effect of changes in electrolyte composition on cell performance. The test cell configuration used two sintered nickel-oxide electrodes and one pasted zinc electrode. The negative electrode paste consisted of 94 percent $\mathrm{ZnO}, 2$ percent $\mathrm{PbO}$, and 4 percent polytetrafluoroethylene (PTFE). The electrolytes included:

- 30 percent $\mathrm{KOH}, 1$ percent L1OH saturated with ZnO

- 15 percent $\mathrm{KOH}, 1$ percent $\mathrm{LIOH}$ saturated with $\mathrm{ZnO}$

- 15 percent $\mathrm{KOH}, 15$ percent $\mathrm{KF}$ saturated with $\mathrm{ZnO}$ and LLOH

- 22 percent $\mathrm{K}_{3} \mathrm{BO}_{3}, 1$ percent $\mathrm{L}_{3} \mathrm{BO}_{3}$

The various cells were operated at 100 percent DoD at constant current. The cell capacity was determined at a fixed cut-off voltage of $1.1 \mathrm{~V}$. The zinc electrode changes were followed by mass balance, $x$-ray, and scanning electron microscopy. The change in shape factor was determined by the ratio of retalned capacity to the electrode area loss.

Zinc loss due to migration was shown to be $30-50$ percent. The capacity loss rate was decreased by the presence of the alkali borate and the alkall fluorlde, and zinc dendrite formation was a.lso suppressed. The cell capacity after cycling was determined by the redistribution of zinc on the electrode (change in shape) and charge acceptance by the positive electrode. The shape change varled 
between electrolytes with the shape change decreasing with the decreasing solubility of zinc hydroxide (as zincate ion) in the electrolyte. The electrolyte containing 15 percent $K F$ showed the least shape change and 11ttle change in the untformity of active material distribution over the zinc electrode.

The earlier studies by $T$. Katan on the reaction profiles developed during the cycling of porous zinc electrodes, reported in references 2,3 , and 4 , have been continued. The experimental technique is to observe the electrochemical behavior in a simulated zinc pore having dimensions simllar to those of a real pore 1.e., about 20 microns. The reference electrodes were prepared by vapor depositing silver onto an alumina substrate. To obtain the spacing between reference electrodes, photographic procedures employing photoresists were used. The substrate was embedded in epoxy and pollshed to obtain reference electrodes for measurements in the simulated 20 micron pore.(7)

A computer controlled data acquisition and programming system was used for data collection. Potentlal-profile Information was obtalned for both constant current and cycled current operation. The pore penetration depth was observed as a function of current density. The potentlal distribution indicated a pore penetration depth of $0.08 \mathrm{~cm}$. Th1s corresponds to $0.02 \mathrm{~cm}$ for a typical commercial electrode. The penetration depth was a function of applied current, the greater penetration occurring at the lower currents. In addition, edge effects became more pronounced with increased current densfty. The movement of the reaction front, $\mathrm{ZnO}$ formation on the surface, was followed by a zone of relatively lower reaction rate. The preclpitation of $\mathrm{ZnO}$ resulted in pore blockage, masking the pore surface and forclng the reaction front to move deeper into the pore. Hydroxyl ion concentration gradients resulted from the formation of $\mathrm{ZnO}$. These gradients were sufficlent to form concentration cells, corresponding to zinc dissolution and precipitation currents of about $0.8 \mathrm{~mA} / \mathrm{cm}^{2}$.

Potential profiles developed from the edges of the zinc electrode toward the center, in the transverse direction, and from the front towards the rear axlally. The results Indicated, that for a cross-sectional current density of $50 \mathrm{~mA} / \mathrm{cm}^{2}$, there was a potential difference of about $6 \mathrm{mV}$ between the edge and interfor of the pore.

The photomicrograph of the pore showed the movement of the zinc from high current density toward lower current density points durfing cycling. The tendency of zinc to form on the edge was observed to decrease with cycling. The effect was to force the zinc toward the center of the plate and to regions of lower current density where the separation diminished the current. 
Based on these studies, Katan attributed shape change to the current density distribution and the reactant concentration distribution. Pore penetration was a function of current density and cycling.

Cairns and coworkers have also conducted mode1 single-pore experiments to study the discharge behavlor of the zinc electrode. (7) The cell design enabled the simultaneous microscopic and potential observations using pores of dimensions comparable to those in commercial electrodes. The reference electrode was a quartzsupported cadmium thin film and was used to provide pore potentialdistribution and hydroxyl-ion concentration data. Discharge behavior was studied in pores of effective radi1 between 14-20 microns at 7,30 , and $1250 \mathrm{~mA} / \mathrm{cm}^{2}$ in $7.7 \mathrm{M} \mathrm{KOH}$. The results obtained were consistent with the dissolution-precipitation mechanism. SEM studies showed signlflcant variations in electrode surface morphology with location in the pore and rate of discharge. Signiflcant hydroxyl-ion gradients, with slow relaxation times at the $30 \mathrm{~mA} / \mathrm{cm}^{2}$ rate, were found to exist within the pore. There was no evidence of electrode passivation at current densities of 7 and $30 \mathrm{~mA} / \mathrm{cm}^{2}$, but passivation was observed at $1250 \mathrm{~mA} / \mathrm{cm}^{2}$.

Closely related studies were conducted by McKubre. (16) $\mathrm{He}$ and coworkers Investigated the influence of convection and zincatefon concentration on the dissolution kinetics and passivation of the anodic (discharge) reaction of zinc. As tn the studies on iron, these studies used rotating disc and 1mpedance measurements. Based on the observations, McKubre proposed that the dissolution proceeds via consecutive one electron changes with $\mathrm{Zn}^{+1}$ as an adsorbed intermediste spectes. Z1nc hydroxide, in a porous and loosely adherent form, was suggested as the first discharge product. At potentials below the passivation potential, the zinc hydroxide separates from the surface as a collold and is in equilibrium with the zincate ion in solution. This equilibrium is controlled by the hydroxyl-ion concentration. The dissolution of the zinc is hypothesized to be catalyzed by the zincate fon, and the rate of dissolution controlled by the rate of diffuston of the zincate fon to the electrode. This autocatalytic effect was confirmed by the impedance measurements, and McKubre suggested that th1s is a plausible mechanism for shape change of zinc electrodes.

Various studies on the effect of the addition of heavy metal oxtdes to the zinc electrode were reported in references 3 and 4. James McBreen and Ellen Gannon have extended these studies to the inclusion of bismuth oxide in the mix of a pasted zinc electrode. (19) The effect of $\mathrm{Bi}_{2} \mathrm{O}_{3}$ additions was investigated by the use of cyclic voltammetry, chronopotentlonetry, polarization meastrements, and scanning electron microscopy. The results 
Indicated that during plate formation most of the $\mathrm{BH}_{2} \mathrm{O}_{3}$ was reduced to metallic bismuth prior to the reduction of the zinc oxide. The blswuth formed a needle-like matrix in the active materlal paste. The presence of $\mathrm{Bi}_{2} \mathrm{O}_{3}$ did not greatly affect the electrode polarizability or the current distribution on the zinc electrode. The deposit of zinc on bismuth was found to be more active than the earlier studied deposit of zinc on lead or indlum. It was suggested that the beneficlal effect of $\mathrm{BI}_{2} \mathrm{O}_{3}$ may be in the prevention of densification of zinc formed during charge.

Earlier studies on the effect of pulsed charging on the reversibility of the zinc electrode were noted in references 3 and 4. McBreen and coworkers have compared dc charging of the zinc electrode with dc charging with superimposed ac sguare waves of vartous amplitudes and frequencles, $0.1-5000 \mathrm{~Hz}$, (20) In the case of dc charging, the faradalc conductance passed through a maximum at $\sim 75 \mathrm{~mA} / \mathrm{cm}^{2}$. The decrease in the faradalc conductance at higher current densities $\left(100 \mathrm{~mA} / \mathrm{cm}^{2}\right)$ wss related to the formation of dense zinc deposits on the electrode surface. At low dc current densities $\left(\sim 30 \mathrm{~mA} / \mathrm{cm}^{2}\right)$, superimposition of ac promotes growth of zinc close to the current collector and results in small amounts of dispersed hexagonal zinc deposits on the current collector. The low current density pulsed charging was beneficlal in that it increased the electrode faradalc conductance and promoted growth of the zinc deposit close to the current collector. Based on the relaxation time of the double layer, it was suggested that the optimum frequency for pulsed charging was between 1 and $10 \mathrm{~Hz}$.

\subsubsection{Zinc/N1ckel-0xide Battery Separator Research}

Previous studies have shown that the separator, both microporous and ton exchange types, and its physical arrangement affect the cycle life of $\mathrm{Zn} / \mathrm{N} 10(\mathrm{OH})$ batterles. This has led to a more intensive Investigation of the modeling, composition, and structure of separators as they influence zinc electrode reversibility.

Douglas N. Bennion and coworkers have been developlng models of membrane transport. Earlier results are belng published.(a) Thts model describes solute and solvent transport across neutral or lon exchange membranes. The model is based on concentrated electrolyte theory and Stefan-Maxwe1l transport equations. The result of the model is a correlation of salt and solvent fluxes through the membrane along with the concentration, pressure, and electrical profiles in the membrane. The model contains two equilibrium and six traneport parameters when applied to the transport of a single salt and water.

(a) Pintauro, P., and D.N. Bennion, "Mass Transport of Electrolytes in Membranes, I Development of Mathematical Model," I\&EC Fundamentals, in press. 
Measurements of the equilibrium properties for the $\mathrm{NaOH}-\mathrm{H}_{2} \mathrm{O}-\mathrm{NaFion}^{\mathrm{R}}$ membrane were conducted to assist in the testing of this model. $(5,22)$ various techniques were used to determine the following parameters:

- membrane-anion concentration

- membrane-water concentration

- membrane fixed-ion concentration

- wet-membrane density

It was determined that at a fixed temperature the water concentration in the membrane decreased with the external concentration of the alkall ( $\mathrm{NaOH})$. The other parameters increased with alkali concentration. The concentration difference and the volumetric flow rate through the membranes were measured, and the membrane-cation transference number determined.

Reverse osmosis experiments were also conducted at $\mathrm{NaOH}$ concentrations of 1,4 and 8 molar and at various temperatures. The results showed that at a glven temperature the flow rate through the membrane decreased with increasing $\mathrm{NaOH}$ concentration; the flow rate for a given concentration increased with temperature.

Related measurements using radiotracers were conducted by R.T. Ruggerl and T.R. Beck. (23) They concluded that the use of radiotracers is a viable technique for determining multiple transport numbers and self-permeability coeffictents in a single experiment. The radiotracer method was reported as being of equal accuracy to the conventional Hittorf method and can be effectively used in the study of multicomponent mass transport in a wide varfety of membranes.

The high cost of Nafion ${ }^{R}$ and the avallability of models for membrane transport have led to the attempt to synthesize alternative materials. Based on the models developed by Bennlon and coworkers, which 1ncludes parallel hydroxyl-1on and water transport, it was postulated that anionic exchaoge membranes would decrease shape change, dendrite formation, and voltage $105 s$ in $\mathrm{Zn} / \mathrm{N1O}(\mathrm{OH})$ batteries. The investigation of the synthesis of such membranes was reported at BECC-6.(5) The capability of crown ethers to dissolve Inorganic salts led to the selection of these compounds for exploration. The size of the ether ring determines the cation selectivity of the crown ether. The incorporation of the macrocyclic crown ethers into the ion exchange membrane is expected to enhance the Ion transport in the $\mathrm{Zn} / \mathrm{NiO}(\mathrm{OH})$ battery and to lead to better performance. 
The elghteen different macrocyclic crown ethers synthesized for investigation are shown in Figure 7. The macrocyclic crown ether most extensively studied, as of June 1984, was compound 7. Th1s was converted to the potassium salt using potassium thiocyante. Membranes contain1ng this salt and polypropylene or a vinylidene chloride-vinyl chlorlde copolymer were prepared. The presence of the macrocyclic crown ether improved the uptake of $4 \mathrm{M} \mathrm{KOH}$ and the membrane conductivity. However, a greater increase in conductivity is required for a practical membrane.

R.S. Yeo and J. Lee are also attempting to synthesize improved membranes for alkaline electrolyte batterles. (5) Their approach is to prepare hybrid separators which contain the properties of both microporous and ion exchange materials. The ultimate objective is a separator materlal which is highly specific for fast transport of the electrolyte while inhibiting zincate-ion diffusion.

The separators are being prepared by the radiation grafting of a monomer, such as methyl acrylic acid, onto a microporous substrate. The extent of grafting was controlled by the concentration of monomer and the radiation dosage. The fon-exchange capactty was directly proportional to the extent of grafting. The 1on selectivity of the Individual hybrid separators was as effective as that exhibited by the corresponding ion exchange membrane. The zincate Ion permeability was much lower for the hybrid separator. The hydraulic permeability was higher.

Based on the above observations and a model of the hybrid separator performance, it was concluded that the new separator materlals should lead to improved cell cycle-1ife. This is to be examined in cell studies.

The inftial studies of J. P. Pemsler and $M$. D. Dempsey on supported Ilquid membrane (SLM) separators were brlefly summarlzed In reference 4. These membranes consist of a microporous separator, such as Celgard ${ }^{R}$ (polyproplyene) or a cellulosic material, infiltrated with highly-specific organic reagents. (5) The latter assist in the control of the transport properties across the separator. A number of lon-exchange reagent/solvent/modifier systems have been investigated. Detałls with respect to the reagent/solvent/modifler combination were not available due to the status of the corresponding patent applications.

The separators showed high specifity, low cost, and low resistivity. Zincate ton transport across the separator was decreased, and there was no penetration of dendrites across the modifled separator during cycling. 
<smiles>[2H]C(=O)c1ccc2c(c1)OCCOCCOc1cc(C(C)=O)ccc1OCCOCCO2</smiles>

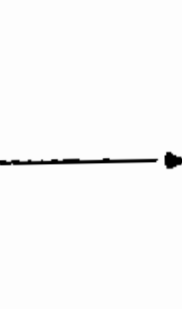

$$
\begin{aligned}
& 1 \mathrm{R}=\mathrm{C}_{13} \mathrm{H}_{27} \\
& 2 \mathrm{R}=\text { pheny } 1 \\
& 7 \mathrm{R}=3 \text {-hepty } 1 \\
& 8 \mathrm{R}=3,4-\text { dimethy1phenyl } \\
& 9 \mathrm{R}=1 \sim \text { naphthyl } \\
& 10 \mathrm{R}=4 \text {-dipheny } 1 \mathrm{yl}
\end{aligned}
$$
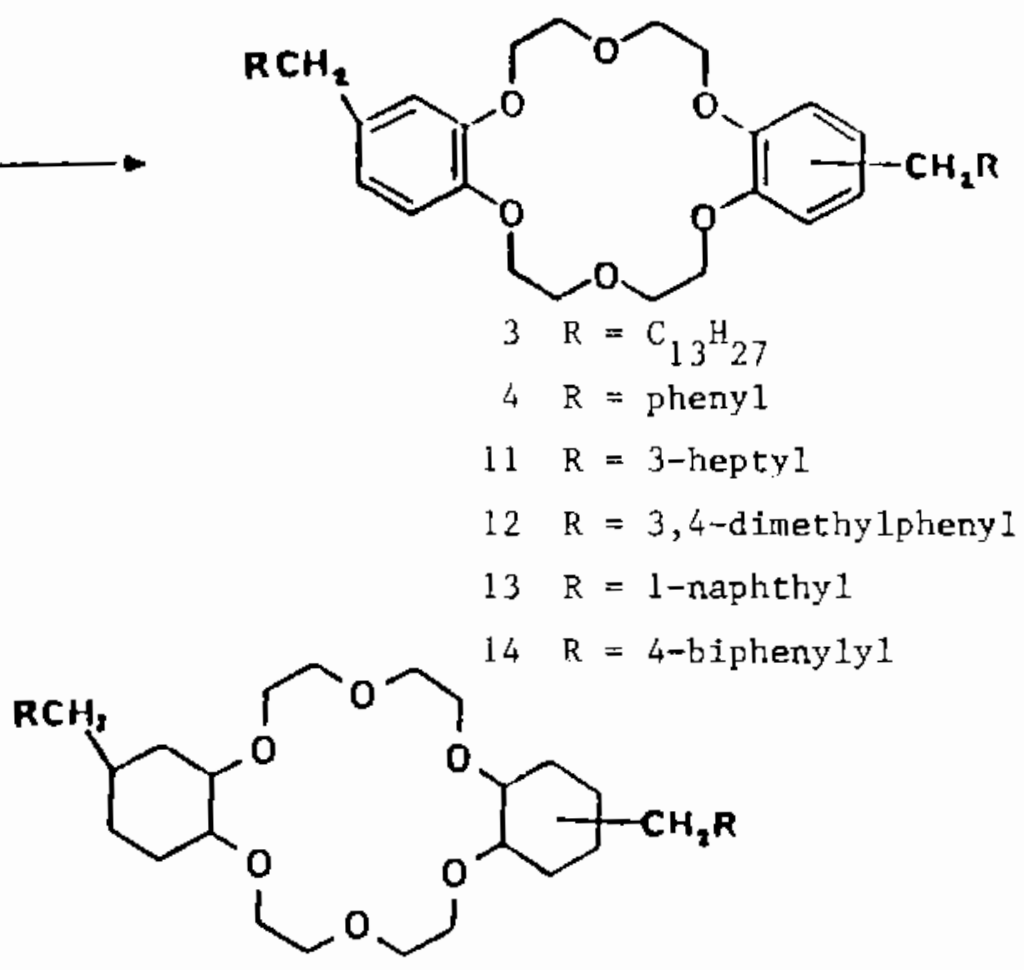

$$
\begin{array}{rl}
5 & R=C_{13} H_{27} \\
6 & R=\text { cyclohexyl } \\
15 \quad R & =3 \text {-hepty } \\
16 & R=3,4 \text {-dinethylcyclohexyl } \\
17 & R=1 \text {-decalyl } \\
18 \quad R & =4 \text {-cyclohexvlcyclohexyl }
\end{array}
$$

\section{MACROCYCLIC CROWN ETHERS}

\section{FIGURE 7}


A modified zinc/nickel-oxide cell design was used to test the performance of the supported 11quid membranes. The new cell design allowed for the total thlckness of the electrodes (one negatlve and two positives), wicks, and the SLM separator without causing excess pressure on the electrode package. Excess gassing, localized heating, and electrolyte-wick dry out were attributed to the pressure on the electrodes in the earller cell designs.

The cells were $11 f e-c y c l e$ tested at $\mathrm{C} / 2$ to 100 percent DoD. Two SLM systems showed cycle-11ves of 250 and 306 resp. Th1s was better than the use of one or two layers of Celgard ${ }^{R}$ but infertor to the use of three Celgard ${ }^{R}$ layers. The performance testing of SLM separators is continuing.

The study of the application of SLM membranes to the zinc/ ferrlcyanide cell and other research related to flow battery systems will be discussed in Chapter 5 .

\subsubsection{N1ckel-Oxide Electrode Research}

Various studies on the electrochemistry, kinetics, and structural changes in the nicke1-oxide electrode were reported in references 1 through 4 . This positive electrode is common to the $\mathrm{Fe} / \mathrm{NiO}(\mathrm{OH}), \mathrm{Zn} / \mathrm{NiO}(\mathrm{OH})$, and $\mathrm{H}_{2} / \mathrm{N} 1 \mathrm{O}(\mathrm{OH})$ batterles.

The earlier-studies of M. J. Madou, summarized 1n reference 4, have been extended and the results of studies of 1mpedance and photoeffects of the nickel-oxlde electrode have been published. (24)(25) The experimental methods used in these studies were primarily photocurrent measurements as a function of voltage, wavelength, and chopper speed as well as the prevtously referenced 1mpedance measurements as a function of frequency and voltage. The measurements were performed on nickel-oxide films of various thicknesses on a nickel substrate. It was found that depending on the electrode potentla1, an n-type or p-type semlconducting oxide can be present at the surface of a nickel electrode. Under 1llumination the n-type oxide glves rise to anodic photocurrents and the p-type oxide, to cathodic photocurrents.

The 1mpedance measurements show that a solid-state diffusion process, presumably of protons through the oxide f1lm, dominates the Impedance behavior for the charged electrode. In the case of the discharged electrode, the impedance behavior is dominated by the space-charge inside the p-type oxide.

The effect of secondary ions in the electrolyte, in addition to $\mathrm{Li}^{+}$from $\mathrm{LiOH}$ which 1 s used as an electrolyte constitutent, on the nicke1-oxide electrode was studied. The lons included $\mathrm{Co}^{+2}$, 
$\mathrm{Fe}^{+2}, \mathrm{Ba}^{+2}$, and $\mathrm{Zn}^{+2}$ which can be present as beneficial additives or untntentional impurities. Three types of electrodes were studied: bare nickel, single crystal NiO, and an electrodeposited N1O film. In the case of the $\mathrm{N} 10 \mathrm{fllm}$, the secondary ions were codeposited with the NiO. The observed effects included:

- the rate of oxygen evolution on nickel-oxide electrodes increases with time

- the presence of $\mathrm{LI}^{+}$delays the aglng of the nicke1-oxide electrode and increases the overpotentlal for oxygen evolution

- the presence of Iron Increases oxygen evolution from the nicke1-oxide electrode

- the presence of $\mathrm{I}_{1}^{+}$does not affect single crystal nickel oxide

- the addition of $\mathrm{CoSO}_{4}$ to the alkaline electrolyte was more effective than the codeposition of cobalt and nickel oxides

These studies resulted in the suggestion that addition of $\mathrm{CoSO}_{4}$ to the electrolyte be investigated as a method for improving the nickel-oxide electrode performance to replace the codeposition of cobalt oxide.

Earlier studies of the nickel-oxide electrode using impedance and electrochemical techniques have been reported by McKubre. (16) These used 20,24 , and 28 weight percent $\mathrm{NaOH}$ as the electrolyte. The temperature range for these studies was $-20^{\circ}$ to $120^{\circ} \mathrm{C}$. Two princtple sources of irreversibility were postulated to explain the observations. Although the thermodynamic properties of the $\mathrm{N} 1$ (II) to $\mathrm{Ni}$ (III) reaction are simflar to those for oxygen evolution, the former predominates at low temperature because of the large overvoltage for oxygen evolution. With increasing temperature the exchange current density for oxygen evolution increases markedly, leading to a decreased charge capacity and coulombic efficiency.

A. irreversibility of the nlckel-oxlde electrode was observed to be assoclated with deep or prolonged discharge, particularly at elevated temperatures. This was demonstrated by using various cathodic hold times durfng the cyclic voltammetry of the nicke1oxtde electrode. The ensuing anodic process required a higher potential and consumed a higher charge with increasing hold time. This can contribute to cell inefficlency depending on the charge condit:ons and temperature. 
Parallel studies on the effect of temperature on the morphological changes occuring during the cycling of the nicke1- oxide electrode have been conducted by Macdonald and his assoclates. The transmission 11ne model (TLM) which they developed for the interpretation of impedance measurements was summarized in reference 3 . Roll-bonded and sintered nickel-oxide electrodes were used in these studies.

Parameters of the TLM were curve-fitted to the experfmental data for porous electrodes at different stages of cycling. The changes in these parameters with cycling time were consistent with experimental observations, and could be attributed to various electrode phenomena. At $23^{\circ} \mathrm{C}$ these included: ${ }^{(7)}$

- the average pore length decreased with cycle number, but always remalned larger than the thickness of the electrode

- the average solid phase resistivity increased with cycle number

- the solution resistance within the pores remained virtually unchanged during the cycle life of the electrode

- the number of active pores decreased after the first few cycles

- the average resistance per pore of the solution and solid phases decreased during cycling with the corresponding decrease in potential across the electrode

- the total impedance of the porous electrode was relatively Insensitive to the impedance of the solution/backing-plate interface Indicating that 1ittle current flows along the entire pore length in the solution.

Degradation of roll-bonded electrodes became more rapid at elevated temperatures, 60 and $100^{\circ} \mathrm{C}$. At the elevated temperatures, the oxygen evolution reaction proceeds at significant rates simultaneougly with the nickel-oxide charging reaction. Sintered electrodes showed more abrupt fallures than the roll-bonded electrodes and broke down rapidly at $100^{\circ} \mathrm{C}$. This indicated that oxygen evolution can also affect the cycle life of sintered electrodes.

The experimental data for roll-bonded electrodes were generally consistent with a degradation mechanism which involves the simultaneous restructuring of the active material and rupture of particle-particle ohmic contacts. The restructuring accounts for 
the decrease in average pore length, decrease in the number of pores, and decrease in the average solution resistance per pore during cycling. The restructuring process was postulated as resulting from dissolution/prectpitation processes occuring in the pores during cycling causing a redistribution of material. The rupture of particle-particle contacts could result from the stresses generated due to volume changes upon the cyclic interconversion of $\mathrm{Ni}(\mathrm{OH})_{2}$ and $\mathrm{NiO}(\mathrm{OH})$.

The above reported studies of McKubre and Macdonald show the importance of temperature control on the performance of the iron/nickel-oxide battery as well as other systems containing rickel oxide. J. Lee, et, al., applied the earlier derlved ANL mathematical model for the thermal balance in batterles to the design of 1ron/nicke1-oxide batteries. (26) Modifications made to the earlier model were summarized in reference 4 , and presented in greater detail in reference 27 . The modifications included:

- dividing a cell into two thermal reglons,

(a) the "core" consisting of electrodes and separators

(b) the "boundary region" consisting of the cell case and electrolyte adjacent to the case

- adding the thermal resistances 1mposed by boundary electrolyte and cell case

- accounting for boundary mass accumulation due to internal convection

To improve the correlations between the results of the solution of the model and the cell design, the dimensionless parameters have been regrouped and the total heat dissipation separated into heat fluxes through individual surfaces via the varlous heat transfer modes.

Table 13 shows the relative importance of some of the thermal parameters on the thermal balance during cell discharge and cell temperature uniformity. These results indicate that the temperature rise of a single cell is strongly affected by the heat generated, boundary conduction, and convective heat transfer. The importance of boundary conduction and convective heat transfer decreases in a five-cell module because of the relative decrease in external surface area. At higher rates of discharge, $C$ or $\mathrm{C} / 2$, the thermal resistance of the cell case and surrounding electrolyte becomes very significant. The temperature unfformity in a cell is most strongly affected by boundary conduction and convective heat transfer. The model has been applied to the design of iron/nickel-oxide cells. 
TABLE 13

REIATIVE IMPOKTANCE OF THERMAL PARAMETERS

IN A TYPICAL IRON/NICKEL-OXIDE CELL

Thernal

Parameters
Cell Temperature Rise

H1gh Rate Low Rate

Discharge Discharge
Ge11

Temperature

Und formit y

$\begin{array}{llll}\begin{array}{lll}\text { Energy delivered } \\ \text { Heat capacity }\end{array} & \mathrm{X} & \mathrm{X} & \\ \begin{array}{l}\text { Total Reaction Heat } \\ \text { Heat capacity }\end{array} & \mathrm{X} & \mathrm{X} & \\ \text { Heat conduction } & \mathrm{X} & \mathrm{X} \\ \begin{array}{l}\text { Heat convection } \\ \text { (due to porosity change) }\end{array} & & \mathrm{X} \\ \begin{array}{l}\text { Boundary conduction } \\ \text { Convective heat transfer }\end{array} & \mathrm{X} & \mathrm{X} & \mathrm{X} \\ \text { Ambient heat transfer } & \mathrm{X} & \mathrm{X} & \mathrm{X}\end{array}$




\subsection{AJKALINE BATTERIES WITH GASEOUS REACTANTS}

Several battery systems that involve a gaseous electrode in an alkali electrolyte are being investlgated. These include hydrogen/ nickel oxlde, iron/air, and aluminum/a1r. Although no effort on the zinc/alr battery is included in this report, consideration is being given to renewing investigation of this system. All of these systems, except for aluminum/air, are electrochemlcally reversible; aluminum/air is beling approached as a mechanically rechargeable battery with the potentlal for a much longer duration vehicle between recharges than the electrochemically reversible batteries.

\subsection{Hydrogen/Nickel-0x1de Battery}

The use and design of the $\mathrm{H}_{2} / \mathrm{N1O}(\mathrm{OH})$ cell as an aerospace system and the design modifications required for terrestial application in stationary electrlcal storage systems were reviewed in reference 3. Based on the earlier design study, a contract to conduct the research and cell design investigations needed to develop a low cost $\mathrm{H}_{2} / \mathrm{NiO}(\mathrm{OH})$ battery was negotlated. This is a foint effort of COMSAT and Johnson Controls, Inc.

The objectives of this investigation of the $\mathrm{H}_{2} / \mathrm{NiO}(\mathrm{OH})$ battery, in addition to lower cost, are a sealed, 100 Ah battery capable of maintenance free operation for 20 years. Alternative prismatic cell designs, rather than the aerospace cylindrical ce11, are beling 1nvestigated. As of June 1984, nine-different 100-Ah cell configurations had been tested. These, together with the cell components used, are 11sted in Table 14. Cells 3 and 9 are being tested at SNL, and were reported to have completed approximately 30 cycles at 60 to 70 percent DoD, and at least one cell had undergone 500 cycles at 70-80 percent DoD (June 1984).

Ce11 9 is the most advanced of the experimental cells. It has a back-to-back electrode construction. The electrochemically impregnated positive electrodes contain cadmium as an additive. Cadmium has been found to give a positive electrode with improved high temperature performance. Cobalt additives were found to produce better low temperature performance. The high platinum loading of the aerospace hydrogen electrode, $7 \mathrm{mg} \mathrm{Pt} / \mathrm{cm}^{2}$, has been markediy reduced by using a carbon substrate with $0.4 \mathrm{mg} \mathrm{et} / \mathrm{cm}^{2}$.

A $7.5 \mathrm{~V}$ ( 6 cel1) 100-Ah battery was fabricated using the more cost effective technology. The cell was operated inside of a pressire vessel. Inttial cycles were used to evaluate capacity, cell matching, and cycle performance stability at various temperatures. The measured capacity was in excess of the 100-Ah destgn goal. Pressure and voltage stability with cycling were achieved, 
TABLE 14

EXPERIMENTAL HYDROGEN/NICKEL-OXIDE HATTEKIES

\begin{tabular}{|c|c|c|c|c|c|c|}
\hline \multirow{2}{*}{$\begin{array}{c}\text { Ce1I } \\
\text { Number }\end{array}$} & \multicolumn{2}{|c|}{ Positlve ${ }^{a}$} & \multicolumn{2}{|c|}{ Negative $b$} & \multirow{2}{*}{ Separator ${ }^{c}$} & \multirow{2}{*}{ Design } \\
\hline & Number & Type & Nuwbe I & Type & & \\
\hline 1 & 22 & JCI & 22 & Platinum & W. R. Grace & Back-to-back \\
\hline 2 & 22 & $\mathrm{JCI}$ & 22 & $10 \%$ Platinum/Carbon & W. R. Grace & Back-to-back \\
\hline 3 & 22 & $\mathrm{JCI}$ & 22 & $10 \%$ Platinum/Carbon & Asbes tos & Back-to-back \\
\hline 4 & 22 & $255 \mathrm{JCI}$ & 22 & $10 \%$ Platinum/Carbon & Asbestos & Back-to-back \\
\hline 5 & 22 & $255 \mathrm{JCI}$ & 22 & $10 \%$ Platinum/Carbon & Agbestos & Reclrculating \\
\hline 6 & 21 & $255 \mathrm{JCI}$ & 22 & $10 \%$ Platinum/Carbon & Asbestos & Recirculating \\
\hline 7 & 21 & $\mathrm{JCI} *$ & 22 & 10\% Plat1num/Carbon & Asbestos & Reclrculating \\
\hline 8 & 21 & $255 \mathrm{JCI}$ & 21 & $10 \%$ PlatInum/Carbon & Agbestos & Back-to-back \\
\hline 9 & 21 & $J C I$ & 21 & $10 \%$ PlatInum/Carbon & Asbestos & Back-to-back \\
\hline
\end{tabular}

apositlve Electrodes

JCI : $0.76-m$ m thlck wet slurry plaque, aqueous 1mpregnation process with cadmlum additive.

$255 \mathrm{JCl}: 0.76-\mathrm{mm}$ thick dry 6inter plaque, aqueous impregnation process with cobalt additive.

JCI* : $0.76-$ mim thick wet slurry plaque, aqueous 1mpregnation process with cobalt additive.

$b_{\text {Wegative Electrodes }}$

Platinum : Standard aerospace platinum catalyst with 6 to $8 \mathrm{mg} \mathrm{Pt} / \mathrm{cm}^{2}$ surface area.

$10 \%$ Platinum/

Carbon : Csrbon/platinum catalyst with $0.4 \mathrm{mg} \mathrm{Pt} / \mathrm{cm}^{2}$ surface area.

cSeparator

W. R. Grace : Inorganic/organic composite conslating of nonwoven polyolefine with luorganic filler materlal.

Asbestos : Quin-T fuel cell grade asbestos.

Reference 5(Dunlop) 
and cell matching, evidenced during capacity measurements, wass maintained at 3.5 Ah to $1.0 \mathrm{~V}$ for all cells in the battery.

The self-discharge characteristics of the battery were similar to those of 1ndividual cel.ls. The uniform capacity of the 1-dividual cells indicated the absence of electrolyte bridging or leakage between cells.

A manufacturlng process for the cells has been developed. The battery cost has been reduced by a factor of 10 , from $\$ 35,000 / \mathrm{kWh}$ to an estimated $\$ 3,500 / \mathrm{kWh}$. Further cost reduction is required to meet the cost goals for a solar stationary battery application.

\subsection{Iron/A1r Battery}

The past efforts on applled research and development of the iron/a1r battery have been descrlbed in the earlier status reports, references 1-4. The need for a long cycle-life bifunctional (charge and discharge) oxygen (a1r) electrode has led to emphasis on the characterization and improved performance of this electrode. Specific objectives are to reduce the polarization at the atr electrode and to extend the cycle life to 1000 cycles. The air electrode performance desired $1 \mathrm{~s}-60 \mathrm{mV}$ vs. $\mathrm{Hg} / \mathrm{HgO}$ at $25 \mathrm{~mA} / \mathrm{cm}^{2}$ on discharge and $480 \mathrm{mV} \mathrm{vs} . \mathrm{Hg} / \mathrm{HgO}$ at $12.5 \mathrm{~mA} / \mathrm{cm}^{2}$ on charge.

E.S. Buzzelli, Westinghouse, reported on recent efforts to 1mprove the oxygen electrode performance. (5) A study was made of various types of carbon for use in the positive electrode. The high-surface-area furnace black, Black Pearls 2000, showed a h1gh rate of corrosion, especially at charging potentials. Shawinigan Black (SB), a medlum-surface-area acetylene black, showed a low corrosion rate and high activity for oxygen evolution. Shawinigan Black is also active for peroxide generation.

Binders to reduce the cost of positive electrode fabrication have also been investigated. (28) This has resulted in finding two alternative binders as potential replacements for PTFE and FEP (fluorinated polyethylene). The materlals are flbrillated polyethylene and fibrillated polypropylene which are marketed by Hercules/Solvay as Pulpex ${ }^{R}$ and Pulpex ${ }^{R}$, respectively. These fibrillated polyalkanes have large surface areas ( $10 \mathrm{~m}^{2} / \mathrm{gm}$ ), large dlameters $(20 \mu)$, and a length of $1 \mathrm{~mm}$. The h1gh surface area gives the fiber strong binding ability and decreases the amount of Pulpex ${ }^{\mathrm{R}}$ necessary. The large dlameter compensates for lower stability. Both Pulpexes ${ }^{R}$ are sufficiently hydrophob1c to be used to prevent wetting without the use of fluorinated polymers. Electrodes fabricated from Pulpex and carbon (0.03 cm thick) showed no leakage of 25 percent $\mathrm{KOH}$ at roon temperature for over 1500 hours. 
The electrodes for $1 n$-cell testing were made using Pulpex ${ }^{R} P$ in the hydrophilic layer and Pulpex ${ }^{R}$ in the hydrophobic layer. The electrodes were pressed at $135^{\circ} \mathrm{C}$ with a sma1l amount of PTFE used as a dusting agent. Two electrodes were cycled in the bifunctional mode using a four-hour $25 \mathrm{~mA}$ charge and a four-hour 12.5 $\mathrm{mA}$ discharge. The performance was better than similar Teflon ${ }^{R}$ based electrodes. Further evaluation is required before these new electrodes can be considered as replacements for the more expensive fluorinated materials.

Investigations to 1mprove oxygen electrodes containing polytetrafluoroethylene (PTFE) as the hydrophobic agent were also conducted. It was found that a PTFE microdispersion with a cationic wetting agent produced longer-lived and better performing electrodes than the earliet used non-1onlc wetting agent. This 1mprovement was attributed to the gelling of the wetting agent by $\mathrm{KOH}$.

The addition of a mixture of nickel (II), Iron (II), and cobalt (II) hydroxides as the cathode catalyst produced a high peroxide ellmination rate as well as good performance as an afr electrode.

The efforts on an 1mproved bifunctional air electrode has led to the following operating characteristics (June 1984):

Best performance

Discharge (25 ma/ $\mathrm{cm}^{2}$ )

Charge $\left(12.5-62.5 \mathrm{ma} / \mathrm{cm}^{2}\right)$

$-100 \mathrm{mV} \star$

$490 \mathrm{mV}$

Best polarization

Discharge $\left(25-125 \mathrm{ma} / \mathrm{cm}^{2}\right) \quad 75 \mathrm{mV}$

Charge $\left(12.5-62.5 \mathrm{ma} / \mathrm{cm}^{2}\right) \quad 30 \mathrm{mV}$

Best Cycle Life

Above $-150 \mathrm{mV}$

250 cycles

Above $-175 \mathrm{mV}$

555 cycles

*A11 voltages vs. $\mathrm{Hg} / \mathrm{HgO}$ electrode

Based on the electrode investigations to date, it was concluded that 1mprovement in the afr electrode structure are more 1mportant for achieving performance goals than are gains in performance achlevable with catalysts as active for peroxide generation as platinum. The $11 \mathrm{fe}$ of the afr electrode is limited by the rate of electrolyte penetration. This rate of penetration is a function of electrode composition, structure, processing, and the charge potential. The rate of carbon oxidation is a function of the charge potential as well as the catalyst present. 
To supplement the research efforts, a study of the prospects for the iron/air battery was conducted at the Jet Propulsion Laboratory. The battery system was modeled mathematically to obtain estimates of battery performance, cost, weight, and size for various EV missions. The input to the battery modei was the laboratory performance data for the Individual electrodes. The results of these model calculations for both near-term (late 1980's) and projected long-term performance are given in Table 15.

Research to understand the functioning and to 1mprove the overall performance of the bifunctional electrode has continued. Eariler studies have been reviewed in references 1 to 4.

Ernest Yeager and coworkers, Case Western Reserve UnIv. (CWRU), have continued investigations on the oxygen reduction and generation reactions in alkaline electrolytes. (7) Various catalysts, including transition-metal macrocyclics, carbon, graphites, and metal oxides are being examined.

As part of the investigation of graphites, various quinones which are adsorptively attached to the basal plane of the graphite substrate have been used as models for studying the reduction of oxygen. The quinones were shown to be active in the reduction of oxygen, the onset of reduction correlating with the voltammetric peak potential for the first one-electron reduction of the quinone to semfquinone. The concluded studies on the generation of the superoxide-radical anton on the basal plane of highly-ordered pyrolytic graphite 1n alkaline solution showed that the reduction of oxygen to peroxide was inhibited. This is in contrast to other carbon surfaces.

The investigation of oxygen reduction using transition-metal macrocyclic complexes adsorbed on carbon have shown that the state of adsorption and aggregation are critical. Mossbauer spectroscopy and transmission electron microscopy showed that Iron phthalocyanine ( $\mathrm{FePC}$ ) on Vulcan $\mathrm{XC}-72$ carbon consisted almost entirely of adsorbed materlal. Cyclic voltanmetry showed a highly irreversible reduction of the iron center from $\mathrm{Fe}$ (II) to $\mathrm{Fe}$ (I) that leads to a less effective oxygen reduction catalyst.

An electrocatalyst based on a partially-pyrolyzed metal-free tetramethoxypheny1 porphyrin $\left(\mathrm{H}_{2}\right.$ TMPP) on Shawlnigan acetylene black (SB) with added hydroxides of nickel, iron, and cobalt has been shown to have superfor activity for oxygen reduction and generation. The $\mathrm{H}_{2}$ TMPP-SB-Ni, $\mathrm{Fe}$, $\mathrm{Co}$ hydroxide system was more activie than related systems contalning only Co. Other combinations of metal hydroxides also have high activity for oxygen reduction. Yeager suggested that these mixed systems Involve different species 
TABLE 15

JPL ESTIMATES OF IRON/AIR HATTERY CHARACTERISTICS

Near-Term Battery Characteristics

\begin{tabular}{|c|c|c|c|c|c|c|}
\hline Misston & $\frac{\text { Energy }}{(\mathrm{kWh})}$ & $\frac{\text { Power }}{(\mathrm{kW})}$ & $\frac{\text { Sp. Ener. }}{(\text { Wh } / \mathrm{kg})}$ & $\frac{\mathrm{Pk} \text {. Power * }}{(\mathrm{w} / \mathrm{kg})}$ & $\left(\$ \frac{\cos t}{/ \text { bat. }}\right)$ & $\frac{\text { Volume }}{\text { (1) }}$ \\
\hline Conmuter & 12 & 25 & 98 & 203 & 889 & 102 \\
\hline Hybrid & 15 & 50 & 72 & 240 & 1524 & 208 \\
\hline EV or Van & 25 & 60 & 90 & 215 & 1831 & 279 \\
\hline Full Perf & 50 & 50 & 130 & 130 & 1744 & 260 \\
\hline
\end{tabular}

Advanced Technology Battery Characteristics

Mission $\quad \frac{\text { Energy }}{(\mathrm{kWh})} \quad \frac{\text { Power }}{(\mathrm{kW})} \quad \frac{\text { Sp. Ener. }}{(\mathrm{wh} / \mathrm{kg})} \quad \frac{\text { Pk. Power }}{(\mathrm{w} / \mathrm{kg})} \quad \frac{\text { Cost }}{(\$ / \mathrm{bat} .)} \frac{\text { Volume }}{(1)}$

$\begin{array}{llrrrrr}\text { Commuter } & 12 & 25 & 126 & 262 & 636 & 81 \\ \text { Hybrid } & 15 & 50 & 93 & 309 & 1031 & 147 \\ \text { EV or Van } & 25 & 60 & 115 & 277 & 1230 & 187 \\ \text { Full Perf } & 50 & 50 & 181 & 181 & 1197 & 204\end{array}$

*From $100 \%$ to $20 \%$ soC

Jet Propulsion Laboratory Report (Contract No. 956731) 
as catalysts for different reactions; for example, one type for oxygen reduction and another type for peroxide decomposition. The long-term stability of the $\mathrm{H}_{2}$ TMPP-SB-N1, Fe, $\mathrm{Co}$ hydroxide system is still to be examined.

PhIlip N. Ross and H. Sokol, LBL, have studled the corrosion of carbon in acetylene black and an HAF-type furnace black $($ ASTM-N 330$)(7)$. Heat treatment of these carbons had little effect on the microstructure of the acetylene black but a marked effect on the microstructure of the HAF-type furnace black. The precursor and heat treated carbons all had the same nominal Brunauer, Emmett, Teller (BET) surface area, but their corrosion rates in alkaline solutions varled significantly, indicating that microstructure is an important fundamental property.

Effort has continued on the use of ${ }^{14} \mathrm{C}$ labeling of acetylene black, together with mass spectroscopy, to determine the current efficlencles for oxygen evolution, carbon dissolution to carbon dioxide, and carbon gasification (to $C 0$ ) during corrosion. $(5,7,29)$ The current efficlencles were found to depend dramatically on potent1al, temperature, and the presence of an oxygen evolution catalyst, $\mathrm{Co}_{3} \mathrm{O}_{4}$. With the uncatalyzed carbon, three corrosion regimes were identified:

- at potentials $<500 \mathrm{mV}$ vs. $\mathrm{Hg} / \mathrm{HgO}$ and temperatures $<50^{\circ} \mathrm{C}$, carbon dissolution is the primary anodic process

- at 500-600 mV vs. $\mathrm{Hg} / \mathrm{Hg} 0$ and $<50^{\circ} \mathrm{C}$ carbon dissolution and oxygen evolution occur at equivalent rates

- at potentials $>600 \mathrm{mV}$ vs. $\mathrm{Hg} / \mathrm{HgO}$ or above approximately $60^{\circ} \mathrm{C}$ at practical potent1als (>450 mV) oxygen evolution and carbon gasification are the dominant anodic processes

Below $500 \mathrm{mV}$ vs. $\mathrm{Hg} / \mathrm{HgO}$ and $50^{\circ} \mathrm{C}$ the current efflclency for oxygen evolution from uncatalyzed acetylene black is sufficlently small that the total anodic current is essentially the corrosion current.

The current efficiency for oxygen evolution increased in the presence of $\mathrm{Co}_{3} \mathrm{O}_{4}$. The rate of the carbon oxidation reactions were also accelerated relative to the uncatalyzed carbon. In addition, significant quantitles of organic products were formed in the presence of $\mathrm{Co}_{3} \mathrm{O}_{4}$. Only trace amounts of organics formed when the carbon was uncatalyzed.

The observations indicate that cobalt oxide does not have to be in physical contact with the reacting carbon black aggregate to produce an accelerating effect on the corrosion reactions. 
Accelerating the rate of oxygen evolution from within the electrode In Itself causes accelerated corrosion of the carbon. Ross postulated that a Co(II)/Co(III) redox mechan1sm is a factor in the catalysis of oxygen evolution and in the catalysis of the anodic corrosion of the carbon. The $\mathrm{Co}$ (II)/Co(III) wechanism may 1nvolve translent solvated species that reside within the porous structure.

\subsection{Aluminum/A1r Battery}

The mechanically rechargeable aluminum/air battery is the subject of one of the major efforts of the ECS program. The current research and system component performance evaluation continues to be under the technical direction of the Lawrence Livermore National Laboratory (LLNL). Varfous aspects of the program are being carrled out by subcontractors. Table 16 shows the participating organizations and the aspects of the cell technology each 18 Investigating. (5)

The objective of the Al/air effort continues to be the development of a power source for general purpose electrical vehicles. The technical effort centers on the evaluation of the abllity of this power source to provide the range, acceleration, and rapid refueling capability of internal combustion englnes at equivalent cost and overall energy efficiency.

The evolution of the Al/air cell has been covered in the preceding status reports, references 1-4. A summary of the status of the development of the battery system, ss of late 1983, is Included in reference 30 .

In the Al/air cell system, Figure 8 , the aluminum anode feeds by gravity into a wedge shaped cell. The sodium hydroxide electrolyte circulates between the cell and a crystallizer, where the supersaturated solution of sodium alumfnate decomposes to regenerate the electrolyte. The aluoinum hydroxide product $1 \mathrm{~s}$ removed perlodically for recycling to the aluminum industry.

The reference battery design used in the on-going program is the wedge shaped cell with wet-side current collection, Figure 8 . The wedge angle is 3 to 6 degrees and the anode area 1 a $600 \mathrm{~cm}^{2}$. Reliable performance requires very uniform consumption of the aluminum during cell operation, and a circult analysis of the performance of the cell was undertaken. The equations were solved for empirical values of anode and cathode polarization, interelectrode resistance, and current collector/anode junction and bus resistances. The current density, $j$, normalized to the current at the maximum value where the wedge enters the cell, depends on the distance from the leading edge according to: 
TABLE 16

AI/AIR BATTERY PROJECT ORGANIZATION

\author{
Lawrence Livermore Laboratory - A. Maimoni \\ Program Management \\ System integration \\ Cell/crystallizer model \\ ELTECH Systems Corp - D. J. Wheeler \\ Prime Industrial Subcontractor \\ Project management \\ Air cathode fabrication and performance \\ Cell component fabrication and performance \\ Fabricate prototype sub-systems \\ Design integrated system \\ Associate subcontracts \\ Alcan - B. O'Callaghan \\ Crystallization kinetics \\ Crystallizer/separator development \\ Crystallizer/separator design \\ Fuel (Al) cycle economics \\ Case Western Reserve Unfversity - E. Yeager \\ Cathode electrodes and catalysts \\ Fundamental oxygen electrochemisty \\ Electromedia, Inc. - F. Solomon \\ Cathode fabrication \\ Cathode structure improvements \\ Cathode cost reduction \\ SRI International - D.D. Macdonald \\ Novel aluminum alloys \\ Characterization of aluminum dissolution reactions \\ Alloy microstructure effects
}




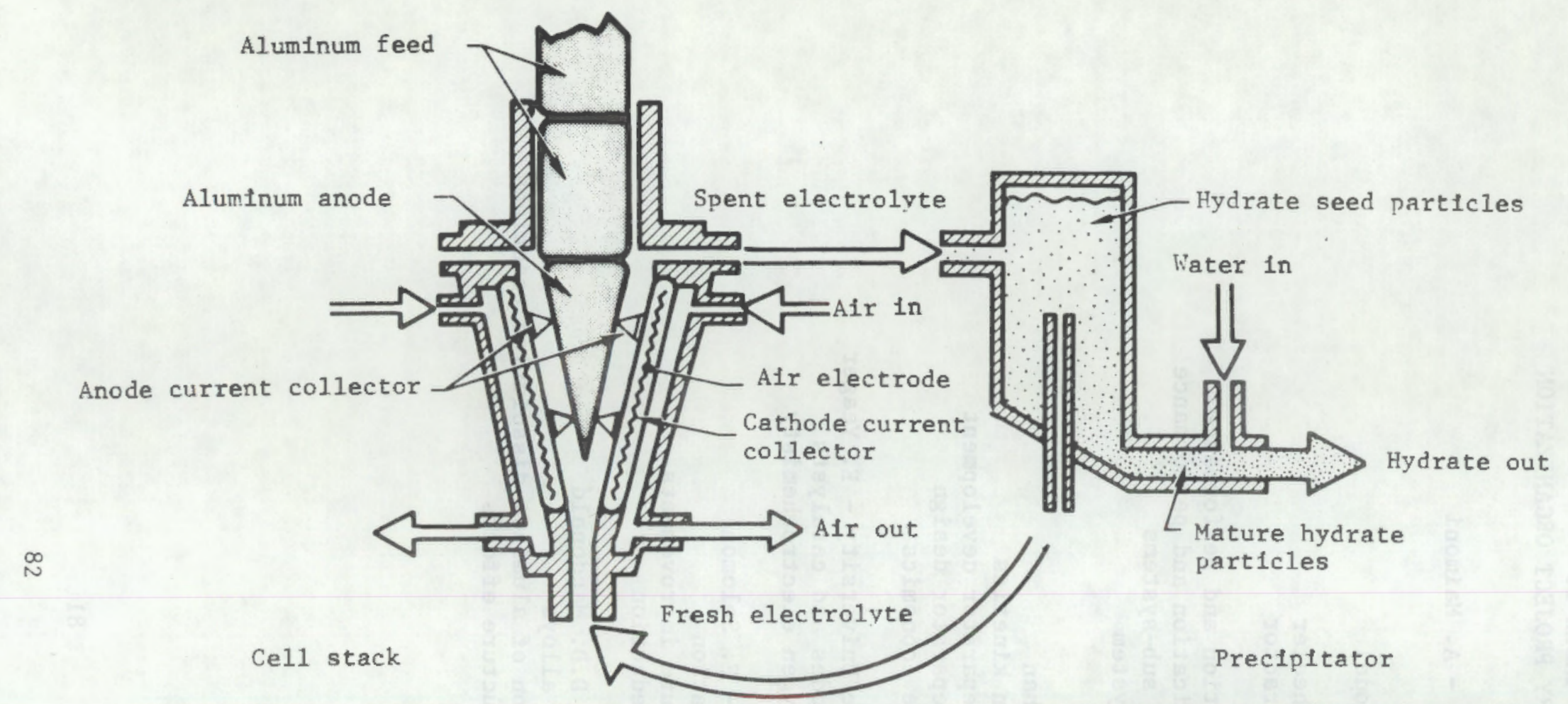

Full ut1lization of aluminum Rapid recharge

Preclpitates $\mathrm{Al}(\mathrm{OH})_{3}$ (hydrate) on seed $\mathrm{Al}+3 / 2 \mathrm{H}_{2} \mathrm{O}+3 / 4 \mathrm{O}_{2}+\mathrm{NaOH} \rightarrow \mathrm{NaAl}(\mathrm{OH})_{4}$ (aq:)

$\mathrm{NaAl}(\mathrm{OH}) \longrightarrow \mathrm{NaOH}+\mathrm{Al}(\mathrm{OH})_{3}$

\section{AL/AIR WEDGE CELL SCHEMATIC FIGURE 8}




$$
j=\cosh \left(x r^{1 / 2}\right) / \cosh \left(r^{1 / 2}\right)
$$

where $\mathrm{x}$ is the relative wedge displacement and $\tau$ is a dimensionless ratio of the resistances operating parallel to the electrodes to those operating normal to the surface. The estimated current uniformity was \pm 3 percent. The maximum deviation from planarity was estimated to be less than 5 micrometers. This is well within the elastic limits of the cell.

The continulty and constancy of the rate of fall of the aluminum anode and the magnitude of the voltage losses at the anode/ current-collector sliding junction are critical tests of the effectiveness of the wedge cell. The experimental data showed that at constant current the fall rate 1 s constant, continuous, and not far from that calculated based on the cell geometry and Faraday's law. The junction losses ( $7 \mathrm{mV}$ ) were approximately 0.5 percent of the cell voltage.

A reference cell has been designed in order to better evaluate the performance of alternative cell materlals and configurations. The cell was designed to minimize electrolyte holdup in the cells, to observe the current distribution constraints, and to provide electrolyte and air distribution mantfolding. The cells were designed and manufactured from NORYL ${ }^{R}$ (polyphenylene oxide) using computer controlled machining. Two complete five cell stacks have been produced. Inftial tests are to be conducted on a one cell assembly to evaluate the performance of the air distribution manifold and air cathode assembly procedures.

Performance, overall system efficlency, and economics will be strongly affected by the ability to recover the spent aluminum in the form of hydrargilltte. This crystalline form of aluminum hydroxide is compatible with current aluminum recovery technology. The equipment selected by LINL for the evaluation of hydrargillite recovery was the hydrocyclone. A commerclal hydrocyclone supplled by Krebs Englneers was selected for testing in combination with a crystallizer and a wedge cell. Ninety-elght percent of the cyclone overflow was returned to the crystallizer because the untt was large enough to handle the flow from 30-50 cells. Measurements on the suspenston of relatively fine particles $\left(120 \mathrm{~m}^{2} / \mathrm{kg}\right)$ indicated that a separation of 99 percent for a cutoff near an average particle diameter of $13 \mathrm{\mu m}$, could be obta1ned. Based on the tests conducted, it was estimated that three hydrocyclones of the size tested would suffice for the operation of a vehicle battery. The total power requitrement of the three units was estimated as $105 \mathrm{~W}$, less than one percent of the gross average power of a $100 \mathrm{cell}, 18 \mathrm{~kW}$ vehicle battery. 
In the first experiment centrifugal pumps were used to circulate the suspension. The particle population was found to increase, with a steady decrease in average particle size. This was attributed to attrition by the pump impeller and secondary nucleation. Peristaltic pumps, combined with a hydrocyclone, led to lower particle attrition. Further studies are to be conducted using the peristaltic pump and hydrocyclone coupled to a cell and crystallizer. There is particle size regrowth during system rest periods.

The Alcoa rate equation was evaluated during operation of the separator system. The observed rate was then investigated to predict the accumulation of solid $\mathrm{Al}(\mathrm{OH})_{3}$-hydrargillite. These results agreed with the separate experimental mass balance measurements based on Faraday's law; changes in aluminate concentration, and anode weight loss. The conclusions of these tests were:

- the Alcoa rate equation applies to the simultaneous operation of prototype cell and hydrocyclone/crystallizer

- the rate equation was verifled within the range of critical vehicular operation conditions

The coupling between the production of aluminum hydroxide in the cell, its crystallization, and separation is an important step in determining the total battery system operation. A schematic for the total system 1s shown in Figure 9. The understanding of the processes and their interactions is required. At LLNL a first version of a computer code, CRYSP, to describe the evolution of the particle size distribution as a function of the system components and vehicle operating conditions has been completed. There is, however, a lack of the information needed to describe the various processes for crystal nucleation, aggregation, and abrasion. An experimental-calculational study is being conducted to obtain the needed input data. Initially the particle growth mode1, based on the correlation derived by Alcoa, is being used.

Based on the experimental results, an estimate has been made of the welght for a $70 \mathrm{kWh}$ battery. The system components, the basis for the weight determination, and estimated weights are given in Table 17.

John F. Cooper (LLNL) has recently estimated the cost of aluminum fuel. (31) The technical developments and aluminum ingot price increases between 1979 and 1982 were used in the cost projection. The estimate was based on the U.S. Industry Published Price for a distributed 50-1b. Ingot modifled by fabrication, 


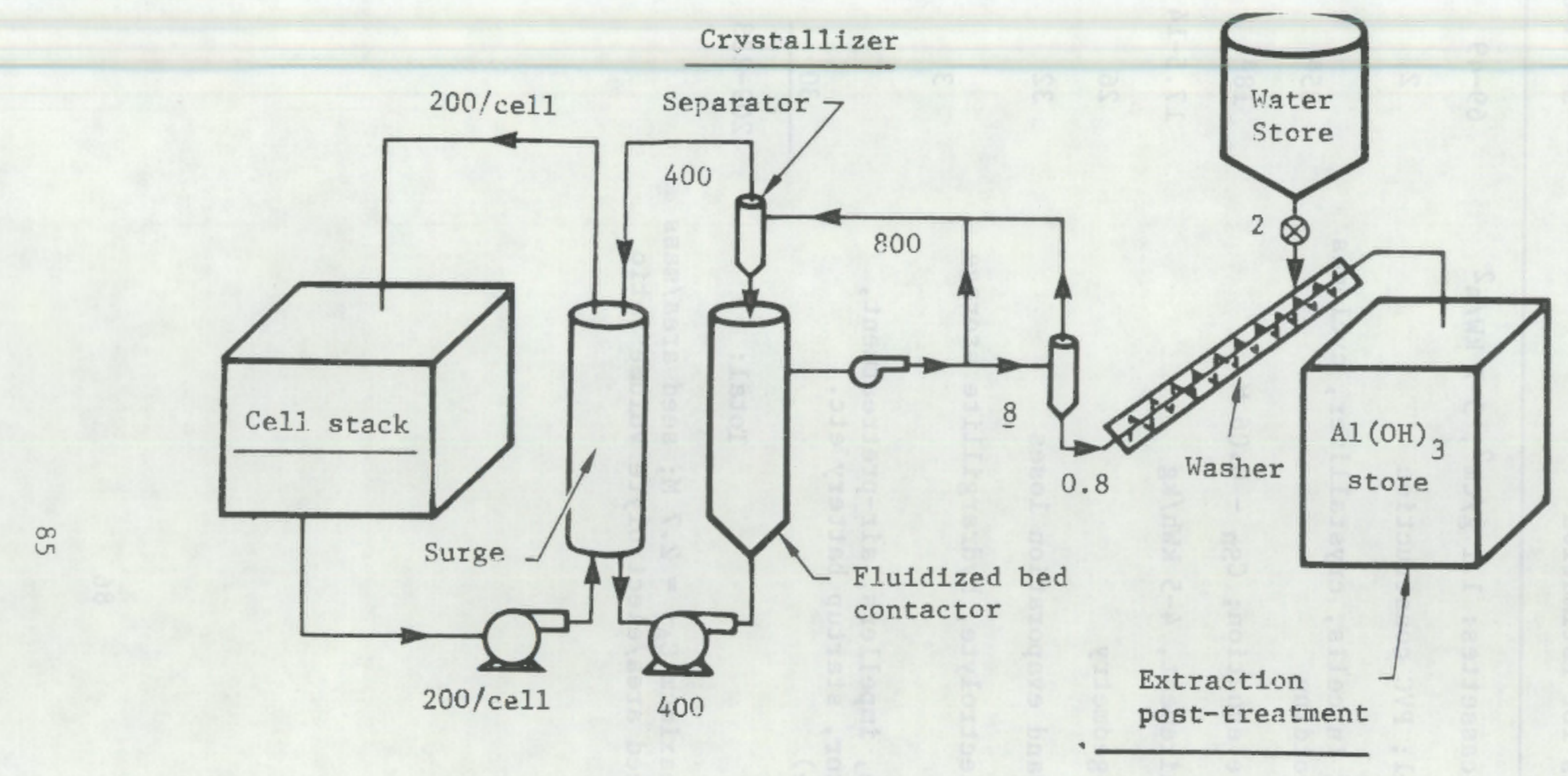

Numbers indicate flow rates $\mathrm{ml} / \mathrm{s}$ 
TABLE 17

Al/AIR BATTERY WEIGHT ESTIMATION

(70 kWh, $31 \mathrm{~kW}$ (peak))

\begin{tabular}{|c|c|c|}
\hline Component & Basis for Estimation & Weight (kg) \\
\hline Cells & M3 wedge cassettes: $1.1 \mathrm{~g} / \mathrm{cm}^{2} ; 5-7 \mathrm{~kW} / \mathrm{m}^{2}$ & $69-49$ \\
\hline Cyclones & Krebs PC-1; PVC construction & 2 \\
\hline Electrolyte & $\begin{array}{l}\text { Contained in cells, crystallizer, cyclones } \\
\text { and manifolding }\end{array}$ & $35^{a}$ \\
\hline Seed & Alcoa rate equation; $\mathrm{C}_{\mathrm{Sn}}-0.06 \mathrm{M}$ & $18^{a}$ \\
\hline Aluminum & Fuel requirement, $4-5 \mathrm{kWh} / \mathrm{kg}$ & $17 \cdot 5-14$ \\
\hline Wedge & $3^{\circ}$ angle geometry & 26 \\
\hline Water & Reaction and evaporation loses & 32 \\
\hline Storage & $\begin{array}{l}\text { Water, electrolyte, hydrargillite storage } \\
\text { tanks }\end{array}$ & 3 \\
\hline Misc. & $\begin{array}{l}\text { Cell case, impellers, air-pretreatment, } \\
\text { drive motor, startup battery etc. } \\
\text { (est1mate) }\end{array}$ & 30 \\
\hline & Total: & $209-233$ \\
\hline \multicolumn{3}{|c|}{$\begin{array}{l}\text { a Temperature }=70^{\circ} \text { at maximum } C_{\mathrm{Al}}=2.7 \mathrm{M} ; \text { seed area } / \text { mass } \\
\text { ratio }=66.1 \mathrm{~m}^{2} / \mathrm{kg} ; \text { seed area/electrolyte volume ratio } \\
=30 \mathrm{~m}^{2} / 11 \mathrm{ter} .\end{array}$} \\
\hline
\end{tabular}


alloylng, premiun purlty, and retail markups analogous to gasoline. A credit for recycled hydrargillite was included. Another important assumption was the energy yield of aluminum as measured by the vehlcular fuel efficiency. For vehicular energy efficiencies of 36-42 gross ton $-\mathrm{km} / \mathrm{kg}-\mathrm{Al}$, fuel estimates are equivalent to liquid frel costing \$0.56-0.94/1iter (\$2.12-\$3.54/gal) (mid-1981 U.S. dollars) used in automobiles with fuel efflciencies of 13.5-19.3 gross-ton-km/1 (35-50 groas-ton-miles/ga1-fuel).

The ELTECH program, inftiated mid-January 1984, increases the scope of the previous ELTECH efforts on the air electrode and aluminum alloys for the anode. Th1s subcontract now includes the Investigation of system components and their integration.

The fabrication and testlng of alternative electrode structures is being conducted by Electromedia and ELTECH. The performance of varlous cathode modifications and thelr fallure modes during cycling and intermittent stand are being evaluated. The ELTECH test cycle consists of: (4)

- 3 minutes at $100 \mathrm{ma} / \mathrm{cm}^{2}$

- 0.5 minutes at $600 \mathrm{ma} / \mathrm{cm}^{2}$

- $10 \mathrm{~m} 1$ nutes at $200 \mathrm{ma} / \mathrm{cm}^{2}$

- 2 hours at standby, electrolyte drained

Gas diffurion electrodes catalyzed by platinum or therma11y treated cobalt tetrameso-p-methoxy phenyl porphyrin (CoTMPP) were tested.

Fallure mode analysis of the platinum catalyzed electrode 1dentifled that over 75 percent of the platinum was lost during 500 cycles; 90 percent was lost in 600 cycles. The thermally-treated CoTMPP showed a loss of 20 percent 1n 800 cycles. Both types of electrodes showed a reduction of micropore surface area and mlcropore volume. The presence of aluminate and stannate in the electrolyte 1ncreased the air electrode cycle 11fe. It was a.lso observed that the presence of platinum catalyzed the oxidation of the carbon electrode.

A stronger, more hydrophob1c conductive wetproof layer was developed at ELTECH. This allowed the alr-side electrical contact desired for simplified battery construction. No loss in voltage performance was observed between electrodes wh th alr and electrolyte side contacts. Combining the improved electrode structure with heat-treated coTMPP catalyst led to an electrode formulation which 
atta1ned over 1400 cycles, close to the 1500 cycle goal established by earlier LINL atudies. Table 18 gives the performance as of late 1983, technical goal, and LINL spectflcations for the air electrode Initial performance.

The study of the effects of alloylng agents on the aluminum anode was performed at Ohio State University and at ELTECH. Current cell testing 1 s being performed using $99.999 \%$ pure aluminum in an electrolyte contalning about $0.06 \mathrm{M}$ sodium stannate. The alloy RX-808 used in previous cell testing is high purity aluminum (99.999\%) with small additions of $\mathrm{Sn}$ and $\mathrm{Ga}$. The presence of $\mathrm{Sn}$ in the alloy or the electrolyte reduces the corrosion of aluminum by the electrolyte, whlle $\mathrm{Ga}$ tends to decrease the overpotential at high current densities. However, the tin deposit is exfollated from the surface during cell operation, accumulates in the electrolyte and might cause shorting of the cell at small anode/cathode separations.

Th1rteen alloys were prepared from 99.99 percent pure aluminum for testing in $4 \mathrm{M} \mathrm{NaOH}$. The alloys had varying amounts of gallium, thallium, indium, and phosphorous. The alloys showed open circult stabllity without the presence of inhibltors greater than the stabllity of RX808, the present reference alloy, plus inhibitor. The stability 1mprovement, depending on the alloy, was gained at the expense of 100 to $300 \mathrm{mV}$ in open circult anode potential.

Anode polarization data 1dentified a dependence of parasitic corrosion rate on alloy composition. Both a positive difference effect and a negative difference effect were observed with the alloys tested, and these affects were correlated to alloy composition. Alloys were developed with coulombic efficlencies superior to $\mathrm{RX}-808$ at current densities at or below $200 \mathrm{~mA} / \mathrm{cm}^{2}$ and were equivalent at higher current densities. On the other hand, the overpotential was greater for most of these alloys.

Preliminary AC Impedance studies of the alloys developed show that hydrogen evolution and alloy dissolution exhibit markedly different transfer functions, and that these two phenomenon may be delineated by the appropriate selection of the dc polarization potentlal. The ac impedance measurement also appears to be useful in assessing the effects of solution phase inh1bitors.

The 1mprovements in the oxygen electrode performance, especially the incorporation of thermally-treated CoTMPP as the catalyst, are in part the result of collaboration between ELTECH and Case Western Reserve Unlvers1ty (CWRU). Earlier studies at CWRU on electrocatalysis for bifunctional alr electrodes (1ron/alr cell), for oxygen cathodes for Industrial processing, and for fuel cells 
TABLE 18

Al/AIK CATHODE PERFORMANCE

\begin{tabular}{|c|c|c|c|}
\hline Current Density & $\begin{array}{l}\text { Best Obtained } \\
\text { CoI'MPP }\end{array}$ & Technical Goal & LLNL Specs \\
\hline $\mathrm{kA} / \mathrm{m}^{2}$ & V vs. KHE & V vs. RHE & V vs. RHE \\
\hline .1 & 807 & 841 & 836 \\
\hline 2 & 766 & 830 & 796 \\
\hline 3 & 741 & 823 & 756 \\
\hline$\therefore$ & 706 & 816 & 716 \\
\hline$j$ & 667 & 810 & 676 \\
\hline ij & 583 & 805 & 636 \\
\hline
\end{tabular}


have been summarized in earller status reports, references $1-4$, and publications by Yeager and coworkers.

The investigation of alternative oxygen reduction electrocatalysts, electrode structures, and the mechanism of electrode detertoration are 1ncluded in the CWRU effort. Both electrochemfcal kinetic techniques, e.g., linear sweep voltammetry, rotating ring disc, and oxygen generation and non-electrochemical methods for surface composition and structure determination are being used.

The emphasis 1s on the use of metal macrocyclics for electrocatalysts and on the carbon electrode supports. Over 30 different macrocyclics have been investigated. The elements of the first, second, and third transition groups of the perlodic table are included in the metals studies. Included among the ligands used are the phthalocyanines, porphyrins, tetraazaanulene, a hexaazamacrocycle, and polymertc phthalocyanines. The macrocyclics, with and without metal lons, have been incorporated into the electrode and studied both before and after heat treatment.

Since the December 1982 BECC meeting, much of the CWRU research has been 1nvestigating 1ron tetrasulfonated phthalocyanine (FeTSPC) as a catalyst. This compound has been found to catalyze the four electron reduction step of oxygen to water or hydroxyl ion over a substantial potential range without the formation of hydrogen peroxtde. Much electrochemical and spectroscopic data have been obtained for FeTSPC as well as for $\mathrm{Co}$, $\mathrm{Cu}$ and $\mathrm{H}_{2}$ TSPC's. Results with surface enhanced Raman spectroscopy (SERS) of monolayers of these compounds on silver single crystals support earlier findings on polycrystalline sllver, 1.e., the TSPC's are orlented perpendicular to the surface. The corresponding non-sulfonated macrocyclics are probably oriented parallel to the surface.

Molecular orbital (MO) calculations conducted at CWRU indicated that substituent groups on the phthalocyanine ligand or replacement of carbon atoms in the benzo rings with nitrogens should only affect the MO energy levels by a minor extent. Experimentally the voltammetry for FePC was found to be simflar to that of FeTSPC.

The effect of the replacement of $\mathrm{C}$-atoms by $\mathrm{N}$-atoms was examined by using $\mathrm{Fe}$ (II)-tetra-3,4-pyridinoporphyrazine (FeTPPA). Its voltammetry and the $\mathrm{pH}$ dependence of the voltammetric peaks are similar to those for FeTSPC. The oxygen reduction behavior was somethat different from that of FeTSPC, but it still exhibited a relatively wide potential region in which the $0_{2}$ reduction appeared to Involve 4 electrons, with no detectable generation of peroxide. 
To asslst in the 1nterpretation of the cyclic voltammetric peaks observed during the investigation of the oxygten electrocatalysis of Fe(II)TSPC, Mossbatier spectroscopy is being used. This gives infornation on the bonding between the oxygen and iron during the reaction. Based on the Mossbauer spectrum taken with the e? ectrode held at $-1.05 \mathrm{~V}$ vs. $\mathrm{Hg} / \mathrm{Hg}$ ) led to the conclusion that the oxygen reduction proceeds by an electrochemical step (E) followed by a chemical step (C), i.e., an EC mechanism:

$$
\mathrm{HO}-\mathrm{Fe}(\mathrm{II}) \mathrm{TSPC} \rightleftharpoons \mathrm{HO}-\mathrm{Fe}(\mathrm{I}) \mathrm{TSPC} \rightleftharpoons \mathrm{HO}^{-}+\mathrm{Fe}(1) \mathrm{TSPC}
$$

As noted under the summary of the activities of ELTECH, thermal treatment of Co-TMPP leads to a catalyzed electrode with longer cycle $11 \mathrm{fe}$ and less degradation than Pt catalyzed electrodes. Part of the research at CWRU is to understand the transformations that take place and why these lead to an 1mproved electrode.

High catalyt1c activity has been observed in both alkaline and acid media using electrodes contalning the products of the pyrolysis of iron or cobalt macrocyclics (e.g., porphyrins, tetraazaannulenes, phthalocyanines). The volatile pyrolysis products have been determined using gas chromatography and mass spectroscopy. The residual material on the electrode has been investigated by cyclic voltametry and Mossbauer spectrocopy. The evidence showed the presence of iron or cobalt oxide. The Mossbauer spectra did not show evidence for metal-nitrogen bonding in the residue. However, other observations indicate that some of the nitrogen remains in the electrode.

The research on the heat treatment process indicates the need for the presence of a metal atom. The catalytic activity of metalfree $\mathrm{H}_{2}$ TMPP pyrolyzed on a carbon substrate has been attributed to the fresence of metal impurities in the carbon. Active electrodes can be obtained by adding an iron or cobalt salt to a carbon electrode conraining the preadsorbed metal-free macrocycle and then pyrolyzing. It has also been shown that a catalytically active electrode can be formed when the metal hydroxide is added to the pyrolyzed macrocyclic on a carbon substrate.

The optimum heat treatment temperature is in the range of $450-500^{\circ} \mathrm{C}$ in a n1trogen or argon atmosphere. The temperature depends on the macrocycle, the metal and how it is added, and the carbon substrate.

In alkaline solution, electrodes containing the pyrolyzed metal macrocyclic catalyze the decomposition of hydrogen peroxide. In acid electrolytes, the overall oxygen reduction reaction is catalyzed. Still uncertain is the role of the residual nitrogen, 
assumed to be bonded to the meta1, on electrocatalysis or electrode stability.

It has been observed that with low activity Shawfingan Black the oxygen reduction activity is enhanced by the addition of a second metal hydroxlde, such as nickel hydroxide, to the pyrolyzedcatalyzed electrode. This approach is considered to produce different catalytic sites for oxygen reduction and peroxide decomposition.

It has also been observed that the presence of the pyrolyzed metal macrocyclics modifles the hydrophobicity of the carbon surface and improves the mass transport of oxygen within the electrode. 


\subsection{FLOW BATTERIES}

The flow batteries include those systems which use the electrolyte as the carrier for one or more of the electrode reactants during discharge and charge. The exploratory engineering related to the operation of the flow battery systems is being conducted under the Exploratory Technology Development and Testing Project (ETD), Sandia National Laboratories (SNL). The supporting studies on membranes for flow batteries is also a part of the ETD effort. Supporting research on electrode processes and the modeling of the electrochemical englneering of flow batteries is conducted under the Technology Base Research (TBR) Project of the Lawrence Berkeley Laboratory (LBL).

Four battery systems were discussed in the earlier status reports (references 1-4). These are: $\mathrm{Zn} / \mathrm{Br}_{2}, \mathrm{Zn} / \mathrm{Cl}_{2}$, $\mathrm{Zn} /$ ferricyanide, and the chromous/ferric Redox battery. Advances in the technology of all but the Redox battery were reported at BECC-6. The continuation of the effort on the zinc/chlorine battery is supported by the Electric Energy Systems Program of the DOE and by EPRI.

\subsection{Zinc/Bromine Battery}

The effort on the $\mathrm{Zn} / \mathrm{Br}_{2}$ battery is targeted at systems for stationary electrical storage and for transport. The electric vehicle related investigations are partly supported by the DOE-EHV program. The schemat1c of this battery system was presented in reference 4 . The system essentlally consists of two separate electrode systems with two electrolytes separately clrculated using a microporous separator to minimize their rate of mixing. The zinc-bromide anolyte contains a supporting salt, e.g., KCl, to maintain the conductivity of the electrolyte. The bromine in the catholyte is complexed with an organle reagent thus increasing bromine avallability and decreasing the free bromine concentration. Bipolar cells are used with an Exxon developed "tunnel" shunt current protection system. This was described in reference 4.

During the year preceding BECC-6, Exxon developed a new two plece unit cell with an electrode area of $1200 \mathrm{cn}^{2}$. A $1 \mathrm{kWh}$ battery had completed over 400 cycles, and a $10 \mathrm{kWh}, 78$ cell, b1polar battery had completed over 100 cycles (June 1984). This battery also demonstrated the "tunnel" shunt current protection technique. A $200 \mathrm{~V}, 15 \mathrm{~kW}$ battery was constructed and operated for 50 cycles. A $120 \mathrm{~V}, 20 \mathrm{kWh}$ battery has been built and ts under test. Assembly and part tolerance problems delayed the initlation of testing. 
The battery developments since BECC-5 (December 1982) have enabled improvement in the control of earlier recognized fallure mechanlsms, such as $\mathrm{pH}$ 1ncreases, cathode fouling by residues adhering to its surface, and battery stack sealing problems. More recently identified problems were the warpage of electrodes with cycling and wear of the brushes on the D.C. motors used for electrolyte circulation.

The warpage problem was Investigated using $x$-rays, scanning electron microscopy, and differential scanning calorimetry. The studies Indicated that the carbon-plastic composite blpolar electrode plate absorbs bromine causing a linear expansion of the plate leading to warpage. To overcome the changes in the plate morphology, both thinner and thicker plates were investigated along with the use of relnforcement posts to physically limit the warpage. It had been noted that thicker electrodes, used in an older ce11 design, had sustained 600 cycles without warpage. The overcoming of the warpage problem leaves the brush wear problem, a system auxillary fallure, the primary outstanding difficulty requiring resolution.

Previous1y reported cathode fallures due to the accumulation of separator residues have been decreased. Th1s was accomplished by the better pre-extraction of the residues from the separator before battery assembly.

Extended tests of electrolyte life had completed over 5000 hours or 1000 cycles as of June 1984. These tests showed no decline in electrolyte performance and no evidence of degradation of the bromine complexing agents. Laser Raman spectrocopy and $c^{13}$ nuclear magnetic resonance (NMR) were used to study liquid phase complexation and chemical changes in the bromine complexing agent. To understand the relationshlp of the ratio of bromine to complexing agents on coulombic efficlency, phase equilibrium studies of complexing agents have been conducted. The effect of bromine transport into the anolyte on zinc deposition has also been investigated. These studies have led to new Information which is guiding the modification of some of the system components.

The use of additives in the electrolytes has shown the possibility of extending performance to $-16^{\circ} \mathrm{C}$. No data on the effect of these additives on cell life was reported. The high temperature operation was, in part, limited by the softening of the polyvinyl chloride (PVC) fittings above $70^{\circ} \mathrm{C}$.

The exchange-current densitles for bromine on carbon have been determined. These enable the estimation of the minimum surface areas required in the cathode activation layer. This has con- 
tributed to the development of a new layer for bromine activation having a low kinetic polarization at current densitles as high as $150 \mathrm{~mA} / \mathrm{cm}^{2}$. One $\mathrm{kWh}$ and $15 \mathrm{kWh}$ battery test1ng of this new layer showed Improved voltalc performance. The use of carbon-plastic composite electrodes has increased bromine resistance and reduced ti:e electrode cost.

A new class of resilient plastics, which is resistant to bromine, has been 1dentified. These plastics promise to reduce the battery stack sealing problem.

The earlier developed computer model has been extended to include weight, volume, and state-of-charge effects. Graphic presentations of this model permit design projections for critical battery variables such as separator characteristics, electrolyte conductivity, and zinc utilization.

In addition to the specific improvements noted, improved processing of components offers reduction of cost. An example is the continuous production of the Daramic separator. These processing improvements, together with the use of low cost plastics, have led to the estimate of a battery cost for large scale production of approximately $\$ 28 / \mathrm{kW}$ (1980\$).

Rlchard J. Bellows and coworkers have published a design projection for $80 \mathrm{kWh} \mathrm{Zn} / \mathrm{Br}_{2}$ batterles for bulk energy storage. (32) Some of the characteristics of this system which are important to this application include:

- specific energy-65 Wh/kg, specific power-140-W/kg, and overall dc/dc efficlency approaching 70 percent

- $\quad$ over 400 deep discharge cycles demonstrated

- good charge retentivity on prolonged stand

- low cost materlals and potentially low manufacturing costs

- ease of electrolyte maintalnability and battery repairability

- modular design flexibility

An earlier design study of a $\mathrm{Zn} / \mathrm{Br}_{2}$ battery for electric vehicles had similar manufacturing costs. (33) The projected performance characteristics were simflar: 


$\begin{array}{ll}36-240 \mathrm{~V} & 120 \mathrm{~V} \\ 60-80 \mathrm{Wh} / \mathrm{kg} & 65 \mathrm{Wh} / \mathrm{kg} \\ 130-205 \mathrm{~W} / \mathrm{kg} & 140 \mathrm{~W} / \mathrm{kg} \\ 10-100 \mathrm{kWh} \text { capacity } & 80 \mathrm{kWh}\end{array}$

The EV battery physical design consists of side by side location of the electrolyte storage and circulating compartment and battery stack.

The design of the $20 \mathrm{kWh}$ stand-alone battery that is to be delivered to SNL for evaluation in a photovoltalc system simulation test has the following characteristics: (5)

- $\quad 1200 \mathrm{~cm}^{2}$ battery electrodes

- $120 \mathrm{~V}$ on discharge, capacity $80 \mathrm{kWh}$, peak power (kW-20sec) 30

- two high voltage stacks on elther side of a common mantfold

- modules above the anolyte and catholyte reservolrs and the centrifugal c1rculating pumps

\subsection{Zinc/Chlorine Battery}

The remaining DOE support for the zinc/chlorine battery is 11mited to the cooperative effort with EPRI and PSE\&G on the testing of the $500 \mathrm{kWh}$ unit at the BEST Fac1lity (Section 2.2). Th1s battery system has been developed by Energy Development Associates (EDA), a Gulf+Western Company. Further development of this system for Electrical Energy Storage and for EV application is being continued by EDA.

The $500 \mathrm{kWh}$ power source cons1sts of 10-50 kWh batterles, see reference 4 for detalls. The $500 \mathrm{kbh}$ und was qualified at a Detrolt Edison Substation. Th1s consisted of 11 cycles. The battery showed a dc/dc efficlency of greater than 63 percent and delivered more than the rated $500 \mathrm{kWh}$ of energy. The system was installed in the BEST Facility in September, 1983 and power applied in October, 1983. The PSE\&G basellne operation consisted of 30 cycles. The system had a 91 percent avallability. Through mid-June $1984,40 \mathrm{MWh}$ were delivered. EDA has the objective of installing a $6 \mathrm{MWh}, 2 \mathrm{MW}(3 \mathrm{hr})$, ut1lity battery in 1985.

A $50 \mathrm{kWh} \mathrm{Zn} / \mathrm{Cl}_{2}$ battery was 1nstalled at NBTL in Apr11 1984 for 1ndependent testing and started-up on June 11, 1984. The energy 
output was $49 \mathrm{kWh}$. The electrolyte in this unit had a higher concentration of supporting electrolyte, 4M In KCl plus NaCl, rather than $2 \mathrm{M}$ in $\mathrm{KCI}$.

liDA is also continuing 1 ts development of an $\mathrm{EV} \mathrm{Ln} / \mathrm{Cl}_{2}$ battery. Commercial vans have been used as the battery test vehicies. A range of $97 \mathrm{mlles}(155 / \mathrm{km})$ was obtained at $30 \mathrm{mph}$ (48 $\mathrm{km} / \mathrm{h})$ and 90 miles $(144 \mathrm{~km})$, at $35 \mathrm{mph}(56 \mathrm{~km} / \mathrm{h})$. It showed an acceleration of $0-30 \mathrm{mph}(0-48 \mathrm{~km} / \mathrm{h})$ in 14.5 seconds and a max1mum speed of $55 \mathrm{mph}(88 \mathrm{~km} / \mathrm{h})$.

Among the R\&D issues noted by Charles J. Warde (EDA) are the rate of chlorlne-hydrate formation, the chlorine dissolution rate, and the reduction of the store storage pressure, currentiy $4 \mathrm{psig}$ $\left(1.21 \times 10^{2} \mathrm{kPa}\right)$. The life-time of the graphite electrodes has been shown to be 1 n excess of 1700 cycles.

The target for the Installed cost of the $\mathrm{Zn} / \mathrm{Cl}_{2} \mathrm{EV}$ battery is less than $\$ 50 / \mathrm{kW}$.

\subsection{Zinc Deposition in Acidic Electrolytes}

A common feature of the $z$ inc/halogen systems is the redeposition of zinc from an acidic electrolyte during charge. Investigations to understand the effects of additives and of flow conditions on the morphology of the zinc deposits formed are in progress.

The studies at Brookhaven National Laboratory (BNL) are concerned with the mechanism and morphology of zinc deposition and the role of metal-ion additives on the related phenomena. One of the guiding princlples of these studies are the conclusions of earlier studies that high exchange current densities favor dendrite formation. $(34)(35)$

The rate of zlnc deposition on a glassy carbon substrate was determined to obtaln a measure of the relative kinetics of deposition from hlgh-purity zinc-chlorlde and zinc-bromide electrolytes. The primary technique was the potential-step method. The resultant current translent was related to a simple model for the Instantaneous formation of zlnc nuclef and zinc growth under kinetic control. It was observed that the current transient reaches a steady state. The steady state value is a measure of the rate of growth of zinc perpendicular to the substrate. The results showed that the kinetics of zinc deposition are much faster in zinc bromide than in zlnc chloride. Additions of $\mathrm{KCl}$ as a supporting electrolyte moderately decreased the deposition rate from zinc bromide. The addition of aluminum chloride to zinc bromide resulted in a marked 
decrease in deposttion rate. These results indicated a decreased deposition rate in the presence of a complexing agent with the deposition rate being a function of the strength of the complex.

Experiments on zinc deposition on polycrystalline zinc Indicated that the zinc growth habit depended on crystal orientation. Preliminary experiments on deposition on zinc single crystals showed that the rate of zinc deposition is much faster on the basal plane than on the plane perpendlcular to the basal plane. According to McBreen and Gannon the rlsing current transient for the basal plane is consistent with simultaneous layer growth and the nucleation and growth of three dimensional centers. The flat current transient for the plane perpendicular to the basal plane was interpreted as being consistent with a layer growth mechanism. McBreen and Gannon noted that earlier investigations had shown that beneficlal additives, e.g., lead, promote growth perpendicular to the basal plane whereas deleterious 1mpurities, e.g., copper, promote growth parallel to the basal plane.

An extensive study was conducted at BNL on the effect of additions of $\mathrm{Pb}^{+2}, \mathrm{Bi}^{+3}$, and $\mathrm{T}^{+3}$ Ions on zinc deposition. The cyclic voltametry experiments indicated that in some cases the additive $1 \mathrm{~s}$ deposited on the substrate prior to the deposition of z1nc. The addition of $\mathrm{Bi}^{+3}$ and $\mathrm{Pb}^{+2}$ markedly decreased the rate of zinc deposition at a given potential; the effect of $\mathrm{Pb}^{+2}$ was greater than that of $\mathrm{Bi}^{+3}$.

The study of the effect of the superimposition of square wave pulses on the morphology of zinc deposits showed this to be mostly one of deposit orientation. In general, pulsed charging yielded smooth adherent deposits.

W.C. Hsle and J.R. Selman (IIT) are investigating the following aspects of zinc deposition in zinc/halogen batteries: $(5,7,36)$

- analysis of transport processes In battery electrolytes and their effect on the electrode kinetics of zinc deposition and hydrogen evolution

- experimental deteroination of the growth rate and morphology of microprofiles of denditic type in electrodeposition from battery electrolytes

- determination of the relationship of the dendritic growth characteristics to the electrolyte transport processes and to the electrode kinetics of zinc deposition and hydrogen evolution 
The laboratory investigation consisted of a matrix of experimental measurements of zlnc profiles on a rotating concentric cylinder electrode (RCCE). The matrix conditions included: rotation speed, $\mathrm{pH}$, and current density. Data were obtained for the following:

- growth rate of nodules or dendrites

- overpotential vs. tiue characteristics

- impedance components

The morphology of the deposit was studled by means of 1n-situ optical microscopy and post deposition SEM.

The increase in rotation speed increased the growth rate of profiles; however, the apparent induction time for dendrites to be visible increased with 1ncreasing convection. At 500 rpm and 46 $\mathrm{mA} / \mathrm{cm}^{2}$ a charge loading density of $380 \mathrm{mAh} / \mathrm{cm}^{2}$ could be realized without dendrite formation.

Gas bubbles were observed to cling to most nodule or dendrite tips at $\mathrm{pH}<2$. A few gas bubbles were observed at higher $\mathrm{pH}(2-5)$. The SEM photographs showed that the relationship between gas coverage and micromorphology of the profile tips was apparently due to localized corrosion and shielding by bubbles. The formation of rliges in the flow direction was characteristic of the deposits observed for low-pH deposition at moderate current densities. These characteristics appeared to be connected with gas evolution. The profiles disappeared and single nodules dominated at higher deposition rates.

Impedance measurements over a frequency range of $0.1 \mathrm{~Hz}$ to 10 $\mathrm{kHz}$ were made durling deposition under varlous conditions of the matrix varlables. The measurements were made during current interruptions at regular intervals. The capacity at the high frequency, $10 \mathrm{kHz}$, showed an unusual dependence on loading. This dependence was qualitatively explained by the effect of gas bubbles on the profiles. In the presence of hydrogen bubbles the growth model corresponded more to preferentlal t1p growth or t1p-and-lateral growth. Increased convection tends to change the growth pattern from periodically inhibited vertical growth to preferred tip or t1p-and-latera1 growth.

Zinc deposition kinetic parameters were determined from polarlzation measurements of the RCCE at short deposition times. The exchange current density was found to be in the range of 3-30 $\mathrm{mA} / \mathrm{cm}^{2}$ for $1 \mathrm{M} \mathrm{ZnCI}_{2}$ (with $3 \mathrm{M} \mathrm{XCl}$ ) at $25^{\circ} \mathrm{C}$. There were significant unexplained variations in the exchange current densities. 
The equations for the growth of a dendritic profile in a flow channel with perturbed flow and concentration field were developed. These equations were used to calculate primary and secondary current distributions at or near a two-dimenslonal profile. The effect of various parameters, such as the ratio of dendrite height to channel helght, on the current density near the tip was systematically investigated. The specific results are to be published.

\subsection{Zinc/Ferricyanide Battery}

The evolution of the zinc/ferricyanide battery has beed described in references 2, 3 and 4. The system, be1ng investigated by the Lockheed Missiles and Space Co., consists of anode and cathode compartments separated by an Ion-exchange membrane, such as Nafion ${ }^{\mathrm{R}}$. The negative electrode is an inert substrate on which zinc is deposited during charge. The positive electrode is carbon at which the ferricyanide ion is reduced to the ferrocyanide ion. The anolyte is a solution of zincate ion in sodium hydroxide; the catholyte is a solution of sodiun ferricyanide in sodium hydroxide. Both are ctrculated during cell operation. During discharge zinc oxide and/or zinc hydroxide precipitates from the anolyte and a m1xture of sodium ferr1- and ferrocyanide from the catholyte. An external storage space is required for each of the electrolyte streams. Solution of the solids is required during charge. The overall battery performance has changed only moderately from that given in reference 4.

The effort, since December 1982, has emphasized the investigation of the membrane. (5) The endurance, resistance, and cost of the membrane are critical issues in determining the practicality of this battery system. A number of cost effective nembranes were cyclically evaluated to determine the effects of terricyanide on membrane cycle-11fe. The results indicated the potentlal for a marked improvement over some of the earlier membranes tested. Some alternative membranes endured the ferricyan1de electrolyte with little or no change in performance. The preliminary evaluation tests consisted of 100 capacity cycles at $70 \mathrm{mAh} / \mathrm{cm}^{2}$. The cycle life of selected membranes under cell operating conditions is to be determined. Further modifications of the membranes are required in order to meet the requirements for resistance and ferricyanide transport. Several membranes exhibited a good coulomblc efficlency but also had a high resistance and thus, a lower voltage efficlency. Based on these observations, the ta1loring of membranes to the cell requirements is being undertaken.

One approach to alternative $\mathrm{Zn} /$ ferricyanide battery membranes is that of the SNL staff. Studies of various comperctal and developmental membranes, vere the basis of a stability 
ranking. (5) The best of these was a Japanese materlal wh1ch consisted of a membrane structure of poly(trifluoroacrylic) actd on a base of polyfiuoroacrylic actd and Teflon. In general radiation grafted membranes were sIlghtly more stable than the homogeneous membranes. These observations led to the preparation by RAI Corporation of grafted membranes as specifled by SNL. The eight custom-made membranes were varied by substrate fllm type (PTFE or fluorinated ethylene-propylene (FEP)), substrate thickness, and extent of crossilnking.

The membranes were tested and, In general, had moderately good stability in the alkaline ferrlcyanide electrolyte and provided good coulombic and voltage efficiencies. Cycle 1tves of 200 and overall energy efficlencles of 70 percent were obtained. However, these were not sufficient to provide the cell performance objectives.

The study of the relationsh1p between membrane structure and properties showed that PTFE backings exhibited better selectivities than poly FEP backings at comparable film thickness. The membrane resistances increased with membrane thickness and, in some cases, Improved selectivity was observed at high crosslink densities. After cycling, the membranes lost 60-80 percent of the grafted material and this was accompanied by a loss of 1on-exchange capacity and water. It was also demonstrated that the graft 1088 was attributable to oxidative attack by the electrolyte and this led to decreased coulowblc efflclency. Further syntheses are planned in an attempt to overcome these deficiencies.

The development of supported liquid membranes (SLMs) at Castle Technology Corp (Section 3.2.3.5) Includes SLMs for the zinc/ ferricyanide battery. SLMs with PTFE as the microporous support have passed short term stability tests. The combinations tested exhibited a selectivity of hydroxyl ton over ferricyanide and zincate ions of $10^{4}-10^{5}$ with separator resistances of $1-10 \mathrm{ohm}$ $\mathrm{cm}$. The retention of organlc reagents in the flowing alkaline electrolyte has been a problem.

The group at Lockheed have continued to investigate zinc/ ferricyanide cell design and the auxillarles required for battery operation. The crystallizer that was used to ensure that the electrolyte would be free of sollds has been replaced by a hydrocyclone downstream from the pump and upstream of the electrolyte reservolr of the ce11. The solids are separated by vortex action. The solids in the recirculating electrolyte were less than 50 microns and did not clog the electrolyte circulation system. The required pumping power was estimated as 2-5 percent of the cell output. 
The solublifty of sodium ferricyanide has been determined and an empirical equation dertved for the solubility as a function of temperature and sodium hydroxide concentration.

Ce11s with Nafion ${ }^{R}$ membranes have been tested. The electrode areas have varled from 60 to $1000 \mathrm{~cm}^{2}$. One of the smaller cells, using Naf1on $\mathrm{N}-117$ as the membrane, had a cycle life of 1413. The largest cell, $1000 \mathrm{~cm}^{2}$, had a cycle l1fe of over 340 . The voltalc efficiencles of the Nafion ${ }^{R}$ membrane cells varled from 79-91 percent, the coulomblc efficlency from 83-92 percent, and the energy efficlency from 68 to 84 percent.

Degradation mechanisms were investigated on 60 and $200 \mathrm{~cm}^{2}$ cells after test termination. The observed fallure modes included separator fallure, zinc accumulation, ferrocyanide accumulation in the porous graphite felt electrode, gradual oxidation of the porous felt electrode, Increased contact resistance between the graphite felt and the current collector plate, formation of high resistance films of ferrous hydroxide on electrode or felt surfaces, and general oxidation of contact surfaces.

Bipolar electrode technology is being developed. This is based upon a nickel coated graphite fiber in a thermoplastic compatable with the battery conditions and electrolyte. The composite has a resistivity of between 1 and $0.05 \mathrm{ohm}-\mathrm{cm}$, and readily lends itself to extrustion or thermopressing operations for mass production. The bonding of the composite to a metal end-plate has been demonstrated.

The earlier conceptual englneering design for the zinc/ ferricyanlde system has been refined. Currently it includes a mode1 for ferro-ferricyanide solids management, an improved model of the battery, and projected costs as a function of electrolyte volume and solid to liquid rat1o. The model requires certain thermodynamic properties of sodium ferro- and ferricyantde which are not avallable in the literature. These are to be determined.

Modeling of a $1.57 \mathrm{~kW}$ module has been undertaken by Selman of the Illinols Institute of Technology (IIT). He has estimated that under adlabatic discharge conditions, with a solid to liquid ratio of 0.5 , the temperature rise in the battery would be $25^{\circ} \mathrm{C}$, with a solid to liquid ratio of 0.25 , a temperature rise of $15^{\circ} \mathrm{C}$ was estimated. The mode1 also indicated that adiabatic operation should be more cost effective than 1sothermal operation.

The use of particulate bed electrodes $1 \mathrm{~s}$ most readily adaptable to systems wth circulating anolyte. The studies of James W. Evans, LBL, center on zinc deposition on particulate-bed electrodes in alkall electrolytes. $(5,7)$ Although most closely related to the 
current effort on the zinc/ferricyanide battery, it could also be adapted to the other zinc-negative batterles. For this to be attractive, the performance of the electrode would have to compensate for the additional complexities of a circulating electrolyte such as lower overall efflctency, pumplng and associated plumbing, exte:nal volume for the electrolyte, and increased weight. This may be counterbalanced by inproved cell performance, increased cycle11fe, simpler thermal regulation, and less stringent separator requirements.

The gross behavior of particulate bed electrodes was invest1gated following their invention in the late sixties. Most of these studies did not investigate the transient behavior of these electrodes. The research at LBL has emphasized the potential transients and the electrochemical reaction rates of the processes taking place at the particle surface under unsteady conditions. The research also investigated the mechanism of electronic transport in the particulate electrode and the controlling factors.

The research has centered on fluldized-bed electrodes, i.e., the particles are kept in suspension by the hydrodynamics of an upward flowing liquid, and on falling bed electrodes, 1.e., the particles fall through the electrolyte and are mechanically returned to the top of the electrode. The hydrodynamics of these electrodes make potential transients inherent.

The experimental apparatus employed a dual probe (a Luggin capillary for electrolyte potential measurement and a means for particle potential measurement). The signals were fed into a digital osc1llograph. All the measurements of the dual probe were with respect to the electrolyte potential adjacent to the cell diaphragm. The potential traces were transferred to a microcomputer for statistical analysis. Potential histograms, autocorrelograms, and power spectra were generated for any point in the electrode. The t.tme average of the observed overpotentials showed extremes at the current feeder and the cell diaphragm. These results are consistent with the mathematical models developed for fluldized-bed and porous electrodes.

Potential transients were measured in fluidized- and moving-bed electrodes consisting of copper particles, zinc-coated copper particles, and Sorapec particles. The last are zinc-coated polymer particles for battery applications that are being commerclally developed by a French company. The polymerlc particles are between 300 and $400 \mu \mathrm{m}$ in diameter. The particles are first coated with an electroless deposit of nickel, followed by an electroplated coating of cadmium. The zinc is in contact with the cadmium coating. 
The transients observed in the fluldized beds were distinctly different for the different electrode particles. These differences were attributed to the varying hydrodynamics of the fluldizied bed as a function of the difference between particle and fluid density. The large density differences between the zinc-coated copper and the electrolyte leads to "bubbling" 1.e., reglons of relatively low particle density. This results in fluctations in the local resistivity of the bed. The fluctuations in the case of Sorapec, with a smaller density difference, are less. In spite of the differences in fluctuation rates, the local reaction rate is not directly affected.

\subsection{Chromous/Ferric Redox Battery}

The $\mathrm{Cr}^{+2} / \mathrm{Fe}^{+3}$ battery system differs from the $\mathrm{Zn} /$ halogen and $\mathrm{Zn}$ /ferricyanide bsttertes as $1 \mathrm{t}$ operates with both anode and cathode reactants in solution. The earlier developments were based on the separation of the reactants in the anolyte and catholyte and have been summarized in references 1-4. A major change in the battery operation was reported at BECC-5 and was reviewed in reference 4. Th1s change 1nvolves the use of mixed electrolytes, 1.e., anolyte and catholyte contain chromium and iron lons.

Bismuth has been shown to be an excellent catalyst for the electrochemical oxidation and reduction of chromium lons in the mixed-reactant electrolyte at $65^{\circ} \mathrm{C}$. In addition to its enhancement of the rate of the anodic and cathodic reactions, the high hydrogen overvoltage of bismuth decreases the rate of hydrogen evolution. Another significant feature of bismuth is the ease with which it can be stripped from the surface of the electrode at the end of discharge. The bismuth redeposits at the beginning of the subsequent charge cycle. Th1s makes the negative electrode highly forgiving to operational mistakes, such as overcharging which leads to Iron deposition.

Another operational aspect of the mixed reactant system is its symmetry. When fully discharged the anolyte and catholyte are indistinguishable. Th1s makes it possible to electrically reverse the system if desired. This reversal can be of benefit in countering the electroosmosis and electrodialysis processes that can occur during normal operation. Polarity reversal has been carried out in the laboratory with no harmful effect on cell performance.

The use of a rebalance cell is required due to the evolution of hydrogen at the anode which leads to a lower anodic coulombic efficlency than for the cathode causing an unbalance of reactant concentrations. The earlier rebalance technique was described in reference 1. Th1s has been replaced by an iron/chlorine rebalance 
cell. In this cell, the iron reactant is discharged while chlorine is evolved at a graphite anode. An HCl electrolyte is used. Energy must be supplied to the rebalancing cell resulting in a system energy penalty. Th1s is small as the hydrogen represents only one percent of the charge capacity.

The use of the mixed 1on reactants has changed the requirements for the membrane. This is a result of the diminished need for high membrane selectivity to keep the chromlum and iron lons separate. The emphasis is on a low resistance membrane, stable to the reactant solutions. The membranes selected for testing, primarily cation exchange materlals, were characterized with regard to resistivity and selectivity and then evaluated in a cell. A performance mappling approach was used. Th1s involved constant-current cycles over a range of current densities. These tests showed that for each membrane there was a current density at which the round-trfp energy efficlency was a maximum. The observed optimum current density depended on the membrane characteristics. Energy efficlencies of efghty percent or more were obtained at current densities up to 100 $\mathrm{mA} / \mathrm{cm}^{2}$.

Negotfations have been completed with Standard oil of ohio (SOHIO) for the scale-up and possible commerclalization of the NASA Lewis Laboratory chromous/ferric battery. Direct support of this battery by DOE has been discontinued. 


\subsection{Non-Aqueous Battery Systems}

Three different classes of nonaqueous electrolytes, with corresponding differences in temperature range, have been included in the ECS program. These are in order of increasing operating temperature range: organic, molten salt, and solld electrolytes. Both the organic and molten salt systems concentrate on 11thium anodes. Although sulfur or sulfur compound cathodes are emphastzed, other cathodes are being explored.

\subsection{Organic Electrolyte Batterles}

The DOE support of two different approaches to organic electrolyte batterles were completed in the firat half of calender year 1984. The two systems were lithlum batterles with sulfolane as the electrolyte solvent and the application of conducting polymers, primarily polyacetylene, to batteries. The efforts in these two systems prior to December 1982 have been sunmarized in references 1-4. Research on organic electrolyte systems is being continued.

\subsubsection{Sulfolane Electrolyte Batterles}

The studies at EIC Laboratories, Inc. have been emphasizing the critical factors governing the use of sulfolane: $(6,37)$

- the conductivity of sulfolane electrolytes

- the stability of sulfolane electrolytes

- the ability to cycle 11thium in sulfolane electrolytes

High purfty sulfolane is required to obtain a relfable reference base for the conductivity and stability of sulfolane electrolytes. Several purffication techniques were evaluated. The procedure giving the highest purity waterial consisted of:

- adsorption on activated charcoal

- vacuum distillation

- treatment with alumina

Melting point, the ultraviolet spectrum, and cyclic voltammetry were used to determine the purity of the solvent.

Sulfolane has a high dlelectric constant. The conductivities of IM lithium perchlorate $\left(\mathrm{LIClO}_{4}\right)$ and lithium hexafluoroarsenate ( $\mathrm{LiAsF}_{6}$ ) were determined as $\sim 0.0024$ and $0.0027 \mathrm{ohm}^{-1} \mathrm{~cm}^{-1}$, 
respectively. The electrolyte conductivity increases when an ether is added. The sulfolane electrolytes are 11 quid at room temperature, however, pure sulfolane melts at $29^{\circ} \mathrm{C}$. Sulfolane electrolytes were found to be stable to lithium for weeks when stored at $70^{\circ} \mathrm{C}$.

The cycling stability of sulfolane electrolytes was investigated using a lithium half-cell with a lithium counterelectrode. The cell separator was Celgard 3501 (a treated microporous polypropylene) and a $10 \mathrm{mil}$ polypropylene felt wick. The electrodes and separator were held in compression in a prismatic glass contalner. These cells were cycled at amblent temperature and at 50,70 , and $90^{\circ} \mathrm{C}$. The efficlencles increased with temperatuce. The sulfolane- $\mathrm{LAClO}_{4}$ electrolyte showed the best overall efficlencles, ranging from 78 percent at ambient temperature to 88 percent at $90^{\circ} \mathrm{C}$. The stability of sulfolane to lithium was attributed to the formation of protective films on the metal.

J. S. Foos and L. M. Rembetsy noted the advantages of sulfolane electrolytes for use in lithium secondary batterles:

- the stability of sulfolane to L1 and 1 ts $\sim 5 \mathrm{~V}$ electrochenical window are compatable with a high voltage cell

- the high thermal stability of sulfolane

- the safety of sulfolane, electrolytes with $\mathrm{LIClO}_{4}$ have been heated to decomposition $\left(250^{\circ} \mathrm{C}\right)$ without explosion

\subsubsection{Conducting Polymeric Electrode Cells}

The earlier studies of G.C. Farrington and A.G. MacDlarmid on the use of polymeric electrodes, primarily polyacetylene, as 1ithium battery electrodes were summarized in reference 4 . The electrochemisal cell Invest1gated was $\mathrm{Li} / \mathrm{LiClO}_{4}$ in tetrahydrofuran/ $(\mathrm{CH})_{\mathrm{x}} \cdot(5)$ Current time curves were determined for cells having an anode of $\left(\mathrm{LI}_{\mathrm{m}} \mathrm{CH}\right)_{x}$ where $m=0.01$ to 0.07 . A study of the current-time curves for the reduction of acetylene at a controlled potential, $1.1 \mathrm{~V}$ vs. $\mathrm{L}_{1} / \mathrm{Li}^{+}$, showed that a fresh f1lm had an initial current density of $4-5 \mathrm{~mA} / \mathrm{cm}^{2}$. This decayed within $30-60$ seconds to a plateau of about $0.7 \mathrm{~mA} / \mathrm{cm}^{2}$. When this was repeated by oxtdizing the polyacetylene to $m=0$ and reducing at $1.1 \mathrm{~V}$, the Initial discharge current density was about the same, but the magnitude of the plateau current was reduced. This trend continued with cycling unt1l the plateau disappeared. Th1s indicated that the current density polyacetylene negative electrodes can sustain during reduction grows smaller with cycling. Cycling efflctency also 
tended to decrease as $m$ was increased. At the higher values of $m$ (0.06 to 0.07 ) there was a marked loss in capacity on standing for 24 hours.

Polyacetylene, when oxidized in a non-aqueous cell contalning $1.0 \mathrm{M} \mathrm{LiClO}_{4}$ in propylene carbonate, developed a voltage of 3.4-4.0 V vs. $\mathrm{L} 1 / \mathrm{LI}^{+} \mathrm{ClO}_{\overline{4}}$. Oxidation levels of at least $\left(\mathrm{CH}\left(\mathrm{ClO}_{4}\right)_{0.10}\right)_{x}$ were achieved electrochemically. Reduction to an uncharged state had a coulombic efficiency of nearly 100 percent. However, the electrochemical doping process was only efficient in the presence of a minimum of liquid electrolyte and ultra-clean conditions. The results were similar when an LiAsE 6 containing electrolyte was used. $(38)$

The general conclusion of the studies on the use of doped polyacetylene cells was, that although these show high coulombic efflclency, the low charge acceptance, loss in capacity on cycling, and chemical instability of doped polyacetylene, make this an unpromising waterial for high energy density batterles.

\subsubsection{Organic Electrolyte Battery Research}

Rolf $\mathrm{H}$. Muller and coworkers are continuing their investigations on the structure, composition, and mode of formation of layers on lithium in lithium organlc batteries. $(5,7)$ The electrolytes studied were polypropylene carbonate (PC) and 2-methyl tetrahydrofuran contalning $\mathrm{LiClO}_{4}$ or $\mathrm{LiAsF}_{6}$.

A thin-layer cell with electrode separation of 50 microns was used. This was to olnimize the amount of electrolyte and the effect of electrolyte impurities. The cell was operated inside an inertatmosphere glove box filled with recirculating helium containing less than 1 ppn $\mathrm{O}_{2}, \mathrm{~N}_{2}$, and $\mathrm{H}_{2} \mathrm{O}$. Lithium-amalgam was used to reduce the water content of the solvents and of the helium.

Surface layers formed in the $\mathrm{PC}-\mathrm{L}_{1} \mathrm{ClO}_{4}$ electrolyte were examined by infrared spectroscopy. The film contained lithium carbonate and polymerized propylene carbonate. Electron surface chemical analysis (ESCA) and lon etching showed that the polymerized PC formed in the inner film next to the lithlum and the inorganic compound in the outer layer. The polymer film was determined to be poorly ordered. ESCA analysis also showed that chlorine in various oxidation states had formed, indicating reaction of the $010 \overline{4}$. The relative concentration of the various chlorine oxidation states varied with film depth.

The presence of water in the electrolyte leads to the formation of a protective lithlum oxide film on the lithium. Th1s is bene- 
flclal for shelf life but has low conductivity and can hinder the recharging of the cell. (39)

Lithium deposited on $\mathrm{LI}, \mathrm{Cu}$, and Pt substrates $1 \mathrm{n} 1 \mathrm{M}-\mathrm{LiClO}_{4}$ in $\mathrm{PC}$ or in 2-methyl hydrofuran was found to be very porous. The strlpping of the 11thium deposit from these electrodes showed that the initial deposit had formed an alloy with the $\mathrm{Cu}, \mathrm{Pt}$, and $\mathrm{Au}$ substrates. Surface layers were only present on the unalloyed outer parts of the deposits. This observation led to the conclusion that electrochemically-formed lithium alloys can give active electrodes but with a very limited capacity. The addition of various inhibitors to the electrolyte did not change the 11thium morphology or prevent reaction with solvents.

Various protective-surface layers were formed by reaction with 11thium. Lithium nitride, a materlal with high lonic conductivity, appeared to be promising. Investigation of this protective-surface is continuing with the objective of finding methods of forming thin, uniform films of lithium nitride that are lonic conductors and protective in PC and 2-methyl tetrahydrofuran. The films must also withstand cycling.

Alternative cathodes for use in organic electrolytes are also belng investigated. Charles W. Toblas and Karrie Hanson at LBL have studied the electrochemistry of the $I_{2} / I_{3}$ in propylene carbonate containing $0.004 \mathrm{M} \mathrm{KI}$ and $0.5 \mathrm{M} \mathrm{KAsF}_{6}$. The cyclic voltammetry of the reaction was studied. Based on the observed voltammograms, the following reaction sequence was proposed:

$$
\begin{array}{lll}
2 \mathrm{I}^{-} & \rightleftharpoons \mathrm{I}_{2}+2 \mathrm{e}^{-} \\
2 \mathrm{I}_{3} & \rightleftharpoons & \mathrm{I}_{2}+2 \mathrm{e}^{-}
\end{array}
$$

The validity of the proposed reactions was tested by following the reaction in an optically transparent thin layer cell. Cyclic voltanmograms and the changes in the UV spectra were determined simultaneously. The absorbance of the trilodide ion can be readily distinguished from that of the lodine. The formation and disappearance of the trilodide lon were followed by scanning the UV-viaible spectrum every 30 seconds during a slow ( $1 \mathrm{mV} / \mathrm{sec}$ ) voltammetric sweep. The absorption spectra were consistent with the proposed mechanism.

A general transport model to simulate the voltammograms was developed in collaboration with M. Matlosz (LBL). (40) The Important features of the mechanism are the presence of two electron-transfer steps which have a more complex stolchfometry than $1: 1$. In addition to the electrochemical steps, the model includes 
the effects of mass transport. The results of the comparison of the model to the scan rates below $500 \mathrm{mV} / \mathrm{sec}$ Indicated that the first of the above reactions, lodide ion to lodine, is kinetically inhtbited whereas the electrochemical reaction involving the trilodide ion is reversible.

In addition to the cyclic voltammetry experiments, the stability of propylene carbonate in the presence of chlorine, bromine, and lodine was studied. It was found that the $\mathrm{Cl}_{2}$ and $\mathrm{Br}_{2}$ reactions with $\mathrm{PC}$ were very sensitive to the presence of small amounts of water. The order of stabllity of the halogens in PC was:

$$
\mathrm{I}_{2}>\mathrm{Br}_{2}>\mathrm{Cl}_{2}
$$

It was also observed that lodine and bromine disproportionate in PC, forming the corresponding trihalide lons and probably positively charged halogen Ions.

Research on cathodes for organic electrolyte cells was also conducted at Stanford Univ. by Robert A. Huggins and associates. Tungsten and vanadium oxlde bronzes have been investigated as 11thium insertion type positive electrodes. The kinetics of the electrochemical insertion of lithium into sodium tungsten bronzes, $\mathrm{Na}_{x} \mathrm{WO}_{3}$ (where $0.4<x<0.7$ ), to form mlxed alkall bronzes, $\mathrm{Li}_{\mathbf{y}} \mathrm{Na}_{\mathbf{x}} \mathrm{WO}_{3}$ (where $0<y<0.5, x+y<0.93$ ), have been studied. (41) Single crystals of the bronzes were prepared to measure 1ithium diffusion rates. Powder $x$-ray diffraction, thermogravimetric analysis, and chemical titration were employed to determine the sodium stolchiometry of the tungsten bronze samples. E1ther galvanostatic or potentiostatic techniques were used to measure the chemical diffusion coefficient of lithium in the bronze samples. Thermodyaamic quantities were determined by measuring the Emf as a function of temperature for the cell:

$$
(-) \mathrm{LI} / \mathrm{LiAsF}_{6}(1 \mathrm{M} \text { in } \mathrm{PC}) / \mathrm{LI}_{\mathrm{y}} \mathrm{Na}_{\mathrm{x}} \mathrm{WO}_{3}(+)
$$

The chemical diffusion coefficient of lithium in the mixed cublc tungsten bronzes, $\mathrm{LI}_{y} \mathrm{Na}_{x} \mathrm{WO}_{3}$, at amblent temperature was as $\mathrm{hIgh}$ as $10^{-7} \mathrm{~cm}^{2} / \mathrm{sec}$ for low values of $\mathrm{y}$, but decreased with increasing alkall metal content. Samples with $x=0.7$ accommodated very little lithlum and the diffusion coefficlent decreased rapidly with the increase in $\mathrm{Li}$ concentration. The measured diffusion coefficlent of lithium in the mixed tungsten bronzes was many orders of magnltude greater than the diffusion coefficlent of lithium in cubic $\mathrm{LI}_{x} \mathrm{WO}_{3}$.

Studies of 1Ithium Insertion in vanadium oxtde bronzes have also been reported. (42) The cell used was similar to that for the 
tungsten bronze studies discussed above. In beta-phase vanadium bronzes, $\mathrm{M}_{\mathrm{x}} \mathrm{V}_{2} \mathrm{O}_{5}(\mathrm{M}=\mathrm{Na}, \mathrm{K})$, it was observed that almost two Itthium atoms may be accommodated per formula welght. The shape of the titration curve for $\mathrm{L1}_{\mathrm{y}} \mathrm{K}_{0} .2 \mathrm{~V}_{2} \mathrm{O}_{5}$, 1.e., the Emf vs. L1 content, was explained as the filling of sites within the tunnels of the bronze. The kinetics of the Lt insertion reaction have also been studled.

\subsection{Molten Salt Systems}

The major effort on molten salt systems, through FY82, was the research, development, and performance evaluation of the Li-alloy/ molten salt/FeS battery. This program, centered at ANL, was reviduwed in references 1-4, with a summary of the status of this system at the end of FY82 included in reference 4. Additional details on the status of this battery system have been published in references 43 and 44 which post-date reference 4 . These add detalls but do not change the summarized information. This section will briefly summarize the status of this system, additional information reported, and research on related systems with the potential for improved specific energy and spectflc power.

\subsubsection{L1-a1loy/FeS Batteries}

The final version of the Gould Li-alloy/FeS battery consisted of a mixed L1-Al, L1-S1 powder negative, a FeS positive, and a ternary 11thium salt electrolyte retained in a magnesium oxide powder separator and in the electrodes. (5) The electrolyte content of the various battery components provided good ionlc conductivity with good electrolyte retention. The cell operating temperature was $460^{\circ} \mathrm{C}$.

The Improved cells had specific energles in the range of 80-85 Wh/ $\mathrm{kg}$ and 180-190 Wh/1 at the $\mathrm{c} / 3$ rate. Cell lifetimes of greater than 400 cycles to 100 percent DoD and a peak power of approximately $100 \mathrm{w} / \mathrm{kg}$ at 80 percent DoD were routinely achleved. There were no "Infant mortalities" even when cells had been subject to at least one freeze-thaw cycle. Several Gould cells are under test at NBTL.

The Eagle-P1cher status cells consisted of a Lt-Al anode, L1C1-KCl electrolyte, BN felt separator, and FeS cathode. The varlous cells and groups of twelve status cells showed a wide range of cycle-11ves, Group I from 238 to 1031 and Group IX from 193 to 517 .

By reducing the hole size in the negative electrode retalner, EP achleved tmproved cell cycle-11fe. As of the end of 1983, five of these cells under test at NBTL had achieved the longest cycle 
lives ever reallzed for $\mathrm{EP} \mathrm{Li}-\mathrm{A} 1 / \mathrm{FeS}$ cells and were st1ll under test at that time. ( 8 ) These cells indicate that the modified cell construction may have overcome cell-shorting by protrusions from the negative electrode.

Work at ANL had shown that the use of a heavier positive current collector gave a marked increase in the spectfic power of the Li-alloy/FeS cells. Both the Gould and EP cells showed the benefit of the heavier current collector. The Gould cell showed an 80 percent increase and the EP cell a 30 percent increase in power output by this change in cell design.

Chen and Gibbard have determined the rate of thermal generation in 200 Ah lithium-aluminum/Iron-sulfide cella.(45) FIve-plate, prismatic cells containing three negatives and two positives, boron nitride nonwoven separators, and molten LICl-KCl-LIF electrolyte were used in these studies. Two independent methods were employed. The first was based on preclse measurements of the cell voltage as a function of temperature and state-of-charge comblned with measurements of the overpotentlal during discharge. It was found that the temperature derivative of the cell potential varied strongly with temperature and DoD. For fully charged or discharged cells the temperature coefficlents of the electromotive force vere negative. However, for partially discharged (23-27 percent DoD) cells, two linear portions were observed. Over the lower portion of the temperature range the temperature coefficients were negative; over the higher portion of the temperature range the coefficlents were positive. This behavior was attributed to the transition between $\mathrm{J}$-phase ( $\mathrm{L}_{1 \mathrm{~K}_{6}} \mathrm{Fe}_{24} \mathrm{~S}_{26} \mathrm{Cl}$ ) and $\mathrm{x}$-phase $\left(\mathrm{L}_{2} \mathrm{FeS}_{2}\right)$ formation. For cells discharged 50 percent or more, only negative slopes were found over the temperature range of $400-500^{\circ} \mathrm{C}$.

A high temperature battery calorimeter was designed and bullt for the direct experimental measurement of the rate of thermal energy generation. The calorimeter was designed with a temperature range of $400-500^{\circ} \mathrm{C}$, a sensitivity of $1 \mathrm{mH}$, and an upper limit of heat flow of $50 \mathrm{~W}$. Problems with the nickel foll heaters limited the calorimeter operating temperature to $410-435^{\circ} \mathrm{C}$.

There was good agreement between the heat generation calculated from the thermodynamic data and the direct calorlmetric measurements. The temperature derfvative of the cell potential of the L1-Al/FeS cell was a complicated function of temperature and state of charge. The cell reaction for fully charged and fully discharged cells was exothermic. Above $430^{\circ} \mathrm{C}$, a part of the discharge process was endothermic. 


\subsubsection{Research on LI-alloy/Metal Sulfide Batteries}

The conclusion of the L1/alloy/FeS battery development effort has led to the rein1tiation at ANL of research on relates systems with the potential for providing alternative cells with greater spectflc energy and power, and which can satisfy the other criteria of cycle-life, cost, and sultability for EV or stationary energy storage. Some of the earller efforts were summarized in references 1-3. The current effort is emphasizing the 1nvestigation of the k1netic and thermodynamic properties of LI-S1 ${ }_{43} \mathrm{LI}-\mathrm{Al}-\mathrm{S} 1, \mathrm{FeS}_{2}$, $\mathrm{NI}_{3} \mathrm{~S}_{2}, \mathrm{~N} 1 \mathrm{~S}$, and $\mathrm{N}_{2}$ as electrode materials. (43)

New methods were developed for characterizing active materials according to usable specific power and power sustaining capability. Half-cell experiments were designed with electrodes of $0.7 \mathrm{~cm}^{2}$ with capacities of $0.25-1.5 \mathrm{Ah} / \mathrm{cm}^{2}$. The test conditions gave a nearly one-dimensional current distributlon. Working electrode potentials were measured using reference electrodes developed by L. Redey and D.R. Vissers of ANL. $(46)$ The electrode performance was evaluated by galvanostatic cycling, by current-1nterruption electrode potentlal relaxation (CIPR) measurements, and by high current pulse techniques. The measurements were used for the numerical characterlzation of the electrode kinetics in terms of the area specific resistance (ASR) (ohm-cm ${ }^{2}$ ). The ASR values are obtained by dividing the time-1nstant values of either the polarlzation durfing high intensity pulses $\left({ }_{1} A_{S R_{t}}\right.$ ) or the potential relaxation after current interruption $\left({ }_{o} A R_{t}\right)$ by the applled current density. The values for the area specific resistance were independent of the current density in the range of $0-200 \mathrm{~mA} / \mathrm{cm}^{2}$. The ASR values were used to compare the kinet1c behavior of different electrodes.

To compare the power-related performance of electrodes, Redey and coworkers introduced the parameter, power indicator (PI). This parameter quantitatively indicates the peak-power and the peakpower-sustalning characterlatics of the electrode. The PI was calculated from the ASR and the potential span that was avallable for useful electrical work durlng a specific duration of a high intensity current pulse. This approach also enabled the estimation of charge acceptance during a high charging pulse, such as regenerative braking.

Alloys of L1-Al-S1 were 1nvestigated to determine whether or not such a mixture would retain the power capab1lity of L1-AI and the capacity of L1-S1. (5) Two compositions of the Al-S1 alloy matrix for use in tertlary-alloy negatlve electrodes were prepared: $\mathrm{Al}_{0.88} \mathrm{SI}_{0.12}$ and $\mathrm{Al}_{0.5} \mathrm{SI}_{0.5}$. The electrolyte used was 9.6 w/o LiF-22.0 w/o L1Cl-68.4 w/o L1Br. The ASR's for the ternary 
alloys were signiflcantly lower than for L1-S1 alloys of the same L1 content. The specific energies of the ternary mixtures were higher than for comparable Li-A1 negative electrodes. The ternary electrode offers a compromise of the power capability and capacity of the binary LI-Al and LI-SI electrodes, resp.

Spectroscoplc studies of the $\mathrm{LIS}_{\mathbf{x}}$ specles formed during the charging of $\mathrm{LI}-\mathrm{Al} / \mathrm{FeS}$ cells have been reported. (47) Two methods of preparation of $\mathrm{LIS}_{\mathbf{x}}$ were used, one chemical and one electrochemical. The results of the observations conflrmed earlier studies that more than one sulfide/polysulfide spectes was involved. Based on the observations it was concluded that at higher sulfur activities increasing amounts of soluble polysulfide species can form In LI-Al/S and LI-Al/MS ${ }_{x}$ cells ( $\left.=\mathrm{Fe}, \mathrm{Co}, \mathrm{NI}\right)$.

Iron disulfide and nickel sulfide were investigated as alternative active materials for the L1-alloy/FeS cell. Earller results on $\mathrm{FeS}_{2}$ vere summarized in reference 4. The chemistry of the four plateaus observed during the discharge of $\mathrm{FeS}_{2}$ was summarized by the following compositional changes:

$\mathrm{FeS}_{2} \rightleftarrows \mathrm{LI}_{3} \mathrm{Fe}_{2} \mathrm{~S}_{4} \rightleftarrows \mathrm{LI}_{2+x} \mathrm{Fe}_{1-\mathrm{x}} \mathrm{S}_{2}+\mathrm{Fe}_{1-\mathrm{x}} \mathrm{S} \rightleftarrows \mathrm{LI}_{2} \mathrm{FeS}_{2} \rightleftarrows \mathrm{LI}_{2} \mathrm{~S}+\mathrm{Fe}$

The ASR values showed that the high resistance of the electrode during discharge limits its usable capacity and power. The resistance was espectally high in the $\mathrm{LI}_{3} \mathrm{Fe}_{2} \mathrm{~S}_{4}$ stage of the discharge sequence. (7)

The thermodyamics of the transition:

$$
\mathrm{LI}_{3} \mathrm{Fe}_{2} \mathrm{~S}_{4} \rightleftarrows \mathrm{LI}_{2+\mathrm{x}} \mathrm{Fe}_{1-\mathrm{x}} \mathrm{S}_{2}+\mathrm{Fe}_{1-\mathrm{x}} \mathrm{S}
$$

were determined at various values of $x$ in the temperature range $382-455^{\circ} \mathrm{C}$. (2) An equation was derived relating the electromotive force (Emf) for the reaction to the temperature: $(7)$

$$
E=1.37902+0.00066 \mathrm{~T}\left({ }^{\circ} \mathrm{C}\right) \text {. }
$$

A comparative study of the electrochemistry of $\mathrm{FeS}_{2}, \mathrm{CoS}_{2}$, and $\mathrm{NIS}_{2}$ electrodes in molten LIC1-KCl electrolytes at $400^{\circ} \mathrm{C}$ was conducted at ANL. (48) Cyclic voltammetry was used to determine the Emf's for the changes taking place during the cathodic and anodic transformations. Galvanostatic cycling was used for the Identification of the various phases formed. The cells were cycled repeatedly at current densities of 12 to $60 \mathrm{~mA} / \mathrm{cm}^{2}$. The cells were stopped at various states of charge for subsequent phase studies. The positive electrodes, after removal from the cells, were analyzed by $x$-ray diffraction and metallographic techniques. 
It was observed that the transformations during the electrochemical reduction and reoxidation of $\mathrm{CoS}_{2}$ and $\mathrm{N}_{2} \mathrm{~S}_{2}$ were less complex than for $\mathrm{FeS}_{2}$. The sequences of phases occurring were summartzed as follows:

$$
\begin{aligned}
& \mathrm{CoS}_{2} \rightleftarrows \mathrm{Co}_{3} \mathrm{~S}_{4}+\mathrm{LI}_{2} \mathrm{~S} . \rightleftarrows \mathrm{Cog}_{8}+\mathrm{LI}_{2} \mathrm{~S} \rightleftarrows \mathrm{Co}+\mathrm{LI}_{2} \mathrm{~S} \\
& \mathrm{~N}_{2} \rightleftarrows \mathrm{N} \mathrm{NS}_{2}+\mathrm{LI}_{2} \mathrm{~S} \rightleftarrows \mathrm{NI}_{7} \mathrm{~S}_{6}+\mathrm{LI}_{2} \mathrm{~S} \rightleftarrows \mathrm{Ni}_{3} \mathrm{~S}_{2}+\mathrm{LIS}_{2} \rightleftarrows \mathrm{N} 1+\mathrm{LI}_{2} \mathrm{~S}
\end{aligned}
$$

The sequences are given in the order of decreasing potential vs. Al, Li-Al independently of the sweep direction.

Extended repeated cyclic voltammetry experiments on the same electrode showed that sulfur was lost by the disulfide electrodes. The losses were attributed to nonequilibrlum specles that were involved in the electrochemical formation of the disulfides from the1r precursors. The cycllc voltammetry peaks were also used to derive anodic and cathodic nucleation overpotentials. The reactions, their Emf's vs. Al, LI-Al, and nucleation overpotentials are given in Table 19.(48)

In further studies of the performance of porous nickel-sulfide electrodes, Redey and vissers studied the following electrodes: $(49)$

- $\quad 2.5 \mathrm{~mm}$ thick electrode with $545 \mathrm{mah} / \mathrm{cm}^{2}$ capacity in 44.2 w/o LiC1-55.8 w/o KC1 electrolyte

- $\quad 2.5 \mathrm{~mm}$ thick electrode with $545 \mathrm{mah} / \mathrm{cm}^{2}$ capacity $1 \mathrm{n} 9.6$ w/o L1F-22.0 w/o L1C1-68.4 w/o L1Br electrolyte

- $4.6 \mathrm{~mm}$ thick electrode with $437 \mathrm{mah} / \mathrm{cm}^{2}$ capacity in the all L1 cation electrolyte

The capactities axe based on the $\mathrm{N} 1 \rightleftharpoons \mathrm{N} 1 \mathrm{~S}$ transition.

Electrode potentials were recorded agalnst a L1-Al reference electrode during galvanostatic cycling, current interruption, and the application of high intensity current pulses. Area spectfic resistance (ASR) quantities were determined.

Results of slow cycling at low current densitles gave the phase transformation sequence of reference 48 (see above). At higher current densities the potential shifts occurred prior to the passage of the theoretical number of coulombs for the given transition. Th1s shift was attributed to the potential value being determined by the surface-layer composition which preceeded the internal reaction. The observed current efficlency of less than one was attributed to polysulfide-ion formation which diffused to the negative electrode and caused self-discharge. 
METAL SULFIDE EQUILIBRIUM POTENTIAL AND NUCLEATION OVERPOTENIIAI.S

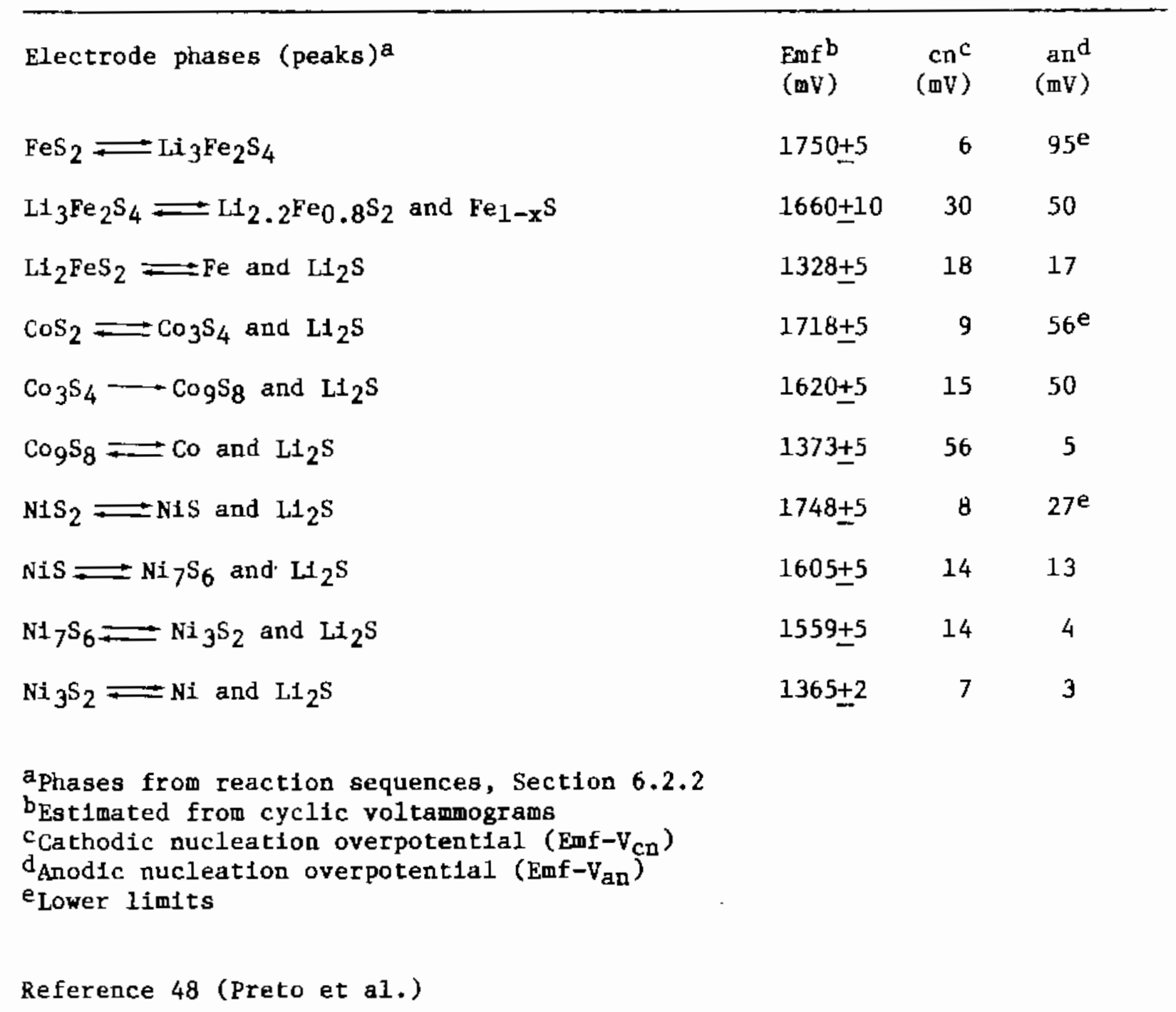


The ASR values determined from the experimental data indicated that both power and active material utilization were higher in the all Li cation electrolyte. For the same electrolyte, the higher loading density electrode gave better power performance. The ${ }_{1} A_{t}$ vs. pulse duration plots indlcated that the nickel sulfide electrode had good peak-power and peak-power sustalning characteristics.

\subsubsection{Research on Alternat1ve Molten Sa1t Cells}

The effort of Huggins and collaborators at Stanford U. on alternative anodes, cathodes, and electrolytes for molten salt and solid electrolyte batterles 1 s continuing. The results of earlier investigations have been summarized in status reports $1-4$. The mo1ten salt related 1nvestigations, since BECC-5 (December 1982), have emphasized systems which are 11 quid below $200^{\circ} \mathrm{C}$ and their compatability with both high lithium activity electrodes and useful positive electrodes.

Further studies on the $\mathrm{LINO}_{3}-\mathrm{KNO}_{3}$ molten salt system have shown that the melting point can be decreased by the addition of $\mathrm{CsNO}_{3}$. (7) The eutectic composition had a melting point of 96 $\pm 2^{\circ} \mathrm{C}$. A solid lithium electrode was found to behave reversibly in this ternary electrolyte. Oxidation and reduction potentials of the electrolyte were measured, and $\mathrm{LI}_{1-x} \mathrm{CoO}_{2}$ was shown to be a reversible positive electrode in the melt.

Molten alkall nitrites were also investigated for use as intermedlate-temperature 11 thlum electrolytes. $\mathrm{LINO}_{2}-\mathrm{KNO}_{2}$, with a eutectic melting at $120^{\circ} \mathrm{C}$, was studied by cyclic voltammetry. Lithium and high-lithium activity alloys tend to form a protective layer, attributed to $\mathrm{Li}_{2} \mathrm{O}$, when 1mmersed in the salt. This is similar to the behavior of $\mathrm{L} 1$ in alkali nitrate melts. The growth of the protective layer did not follow the parabollc law. The resistance of the layer decreased with increasing temperature. Alloy electrodes, e.g., L1-Sb, L1-B1, behaved reversibly in the melt. The corrosion rate of lithlum in the nitrite melt was also determined.

The characterization of aluminum as the negative electrode in $\mathrm{L}_{1 \mathrm{AlC}} 1_{4}$ as the electrolyte has continued. (7) The oxidation limit of $\mathrm{LAAlCl}_{4}$ with respect to aluminum deposition and stripping were examined in both basic and acidic melts using complex-1mpedance spectroscopy and cyclic voltammetry. Diffusion was important in basic melts, and the morphology of the aluminum deposits was poor. Wuch higher current densities, $\left(\sim 100 \mathrm{~mA} / \mathrm{cm}^{2}\right)$ could be passed in acldic melts before mass transport became important. Lithium vanadium bronzes were determined to be stable in the acidic $\mathrm{LiAlCl}_{4}$ electrolytes. 
The inftlation of studies at Stanford on ternary alloys for the negative electrodes in molten saits was noted in reference 4. Related work on the LI-Al-S1 system performed at ANL was described earlfer in this section. At Stanford the thermodynamics of LI-Al-S1 were determined electrochemically. The phase diagrams for L1-A1-S1 and for $\mathrm{L} 1-\mathrm{Al}-\mathrm{Sb}$ at $400^{\circ} \mathrm{C}$ were also determined.

The Stanford research activities included an investigation of the thermodynamic parameters, phase equilibria, and electrochemistry of lithium transition metal oxide $\left(\mathrm{LI}_{\mathrm{x}} \mathrm{MO}_{\mathrm{y}}\right)$ compounds. $(50)$ $\mathrm{LiMnO}_{3}, \mathrm{Li}_{5} \mathrm{FeO}_{4}, \mathrm{LiFeO}_{2}$, and $\mathrm{LiCoO}_{2}$ were investigated as possible positive electrodes for high temperature cells having a lithfum or lithium alloy negative and L1C1-KC1 molten salt electrolyte. The usefulness of the transition metal oxides depends on their tendency to reduce to lower valence state oxides. The oxygen partial pressure of the compound $1 \mathrm{~s}$ a measure of this tendency. The equilibrium partial pressure of oxygen above the two oxides in equilibrium is a measure of the free energy of the transition from one valence state to the other.

The reduction of the 11 thium metal transition compound was investigated in cells of the type:

$$
\begin{gathered}
(-) \mathrm{Al}, \mathrm{LI}_{0} . \mathrm{gAl}_{\mathrm{M}} / \mathrm{LICl}-\mathrm{KCl} / \mathrm{LI}_{\mathbf{x}} \mathrm{MO}_{\mathrm{y}}(+) \\
=\mathrm{Mn}, \mathrm{Fe}, \mathrm{Co}
\end{gathered}
$$

The electrochemical reactions were found to be reversible at $400^{\circ} \mathrm{C}$. The current densities used for the diacharge and charge reactions was $5-15 \mathrm{~mA} / \mathrm{cm}^{2}$. Up to $3.0 \mathrm{mols}$ of $\mathrm{LI}$ could be reversibly reacted. The mearurement of the Emf of the cathode as a function of the 1ithium content, i.e., the number of coulombs passed, gave a measure of the free energy change with composition and a means of calculating the oxygen equilibrium pressure.

The ternary compounds with the highest cathodic potential vs. LI were also the ones of lowest stability, 1.e., highest oxygen partial pressure. The relationshtp between cell voltage and oxygen partial pressure 1mposes a maximum voltage of $1.820 \mathrm{~V}$ vs. L1 on LICl-KCl electrolyte cells using oxide cathode materials. This is equivalent to an oxygen partial pressure of $10^{-25}$ atm. This requirement puts a strong limitation on the possibility of developing high voltage Li molten salt cells with oxide cathodes.

\subsection{Solld Electrolyte Batteries}

The solld electrolyte systems center on the use of $\beta$ "-alumina as the electrolyte in elevated temperature batterfes. The Ford sodium/sulfur battery $1 \mathrm{~s}$ one of the major research and development 
efforts of the ECS program and 1s part of the ETD activities. The other solid-electrolyte battery system, which $1 \mathrm{~s}$ in the laboratory resesrch stage, is the sodium/trichlorosulfonium ion cell ( $\mathrm{Na} / \mathrm{SCl} / 3$ ). This uses the $\beta^{\prime \prime-a l u m i n a ~ a s ~ a n ~ I o n ~ e x c h a n g e ~ m e m b r a n e ~ s e p a r a t o r ~ a l o n g ~}$ with a molten salt electrolyte. This effort, and research on alternative solld lonic conductors, both crystalline and glass, are part of the TBR activity. Corrosion by sulfur and sodium polysulfides is also belng Investigated to aid in materlal selection for the $\mathrm{Na} / \mathrm{S}$ system. Included are related studies of corrosion by lithium sulfides.

\subsubsection{Sodium/Sulfur Battery}

Summarles of the patent background and status of the sodium/ sulfur battery, which were part of the technology analysis and transfer studies included In Section 2.5, are summarized as additlonal background to the current status of this battery. Descriptions of the cell and 1ts evolution, up to December 1982, have been presented in references 1-4. Essentlally the basic $\mathrm{Na} / \mathrm{S}$ cell conststs of a sodium anode inside of a $\beta "$-alumina solid electrolyte cylinder, and a sulfur cathode. An electronic conducting material is included with the sulfur and a chromiumplated ateel cylinder acts as the positive current collector.

The patent search at the Pacific Northwest Laboratory (PNL) identified 285 patents on the $\mathrm{Na} / \mathrm{S}$ battery that had been issued between 1968 and 1984. (5) The patent activity reached a peak in 1976 and 1977 with 41 and 40 patents, respectively, being issued in these two years. Recent activity has fallen to about one-half of the peak number of patents. W. Bradford Ashton and coworkers placed these patents in four categories:

- electrode materials or designs

- electrolyte designs (1ncluding fabrication techniques)

- seals and contalners

- overall destgns and operational consideration

of the 285 patents, 58 percent belong to U.S. assignees and the remainder to foreign assignees. British organlzations hold 55 of the forelgn patents, Federal Repub11c of Germany - 28, French - 19, and Japanese - 17 .

The U.S. assignees hold a disproportionately large share of patents related to electrolyte designs and seals and contalners. Forelgn assignees own a greater share of overall design patents. 
The study of the status of the sodium/sulfur battery, at Jaycor, 11sted the following as the Na/S battery characteristics:

- molten anode and cathode reactants separated by a solid electrolyte

- mediuia operating voltage, 1.6-1.8 V

- operat1ng temperature, $300-500^{\circ} \mathrm{C}$

- cell energy efficlency, 70-80 percent

- high speciflc energy, 75-125 Wh/kg

- $\quad 11 \mathrm{fe}, 80-1000$ cycles (100 kWh battery completed 675 cycles)

- comerclalization, 1990

- cost, $-\$ 85 / \mathrm{kWh}(1980 \$)$ in year 2000

The Na/S battery problems noted in the same study 1ncluded:

- restarting difficult if cells are allowed to cool and Bolidify

- infant mortality of cells

- development of inexpensive, corrosion resistant containment

- Insulation need to malntain temperature

- fallure of ceramic electrolyte and cost of electrolyte

The current effort at the Ford Aerospace \& Communications Corp. on the $\mathrm{Na} / \mathrm{S}$ battery 1 s concerned with demonstrating the capabilities of the cells resulting from earlier investigations and continuing efforts to improve the performance and durability of cells made with lower cost materials.

The design, construction, and testing of $\mathrm{Na} / \mathrm{S}$ batteries for electrlc veh1cles and stationary electrical storage applications has been emphasized in the current program. The Electric Vehicle Englneerling Model-1 (EVEM-1) cell has been designed and constructed. Th1s cell was optimized for speciflc energy leading to a small sacrifice in spectfic power. In spite of this sacrifice in speciflc power, a high power capabllity was achleved. This is Important in reducing the total number of cells required for an $\mathrm{EV}$ battery. 
The EVEM-1 cell had a specif1c energy at $\mathrm{C} / 3$ of $145 \mathrm{Wh} / \mathrm{kg}$ and an energy denstty of $300 \mathrm{Wh} / 1$. An EVEM-1 cell had completed over 1000 cycles and tests were continuing as of June 1984. Figure 10 is a Ragone plot for laboratory EV cells and for production EVEM cells. Spectal tests on these cells showed them to be safe and rugged. The special tests included shock and vibration, freeze and thaw cycles between standard charge-discharge cycles, and safety of cells in which the electrolyte was intentionally caused to fall. The profected design goals for the EVEM-1 battery are presented in Table 20.

A battery of 480 EVEM-1 cells was constructed and bench tested. The battery was refurblshed following the bench tests by the replacement of falled cells. The refurblshed battery was placed In an insulated container and shipped to Ford Dearborn for further testing. Shorting of two thermocouples to their buses led to the full discharge of two of the elght modules. After examining the six undamaged modules, they were reconfigured and assembled Into a $360-$ cel1, 240-V battery which is to be tested.

The general features of the $100 \mathrm{kWh}$ stationary energy storage (SES) $\mathrm{Na} / \mathrm{S}$ battery were descrtbed in reference 4 . Th1s 512 cell battery was assembled in January and February 1981 from cells fabricated in the last half of 1980. Ninety-elght percent of the fabricated cells were sat1sfactory. The battery was placed on test in February 1981 and as of 0ctober 1983, three of the four modules had completed 675 cycles with a greater than ninety-five percent avallability. Testing of the fourth module was discontinued after -100 cycles as this module had been damaged due to an equipment fallure. Due to removal of this module and additional cell fallures and capactty decline, the avallable energy decreased from $100 \mathrm{kWh}$ to $60 \mathrm{kWh}$ with a cycle energy efflclency decrease from 75 to 60 percent. This decrease was primarily due to coulomblc inefficlency. The battery was refurbished and the 295 useable cells were retained after $x$-ray inspection and open circult voltage measurement. The tests of the refurbished battery were 1nitiated in Apri1 1984 and had completed 50 cycles with 100 percent coulomb1c efficiency at the time of BECC-6, June 1984 .

Inspection of the falled cells indicated some sulfur side leakage due to container corrosion and also some leakage at the sodtum pinch-off.

The three modules ( 384 cells in all) of the $100 \mathrm{kWh}$ stationary energy storage system descrlbed above underwent a 32 month test. A Weibull statistical analysis of the data indicated the characteristic life of these cells to be -1500 days. 


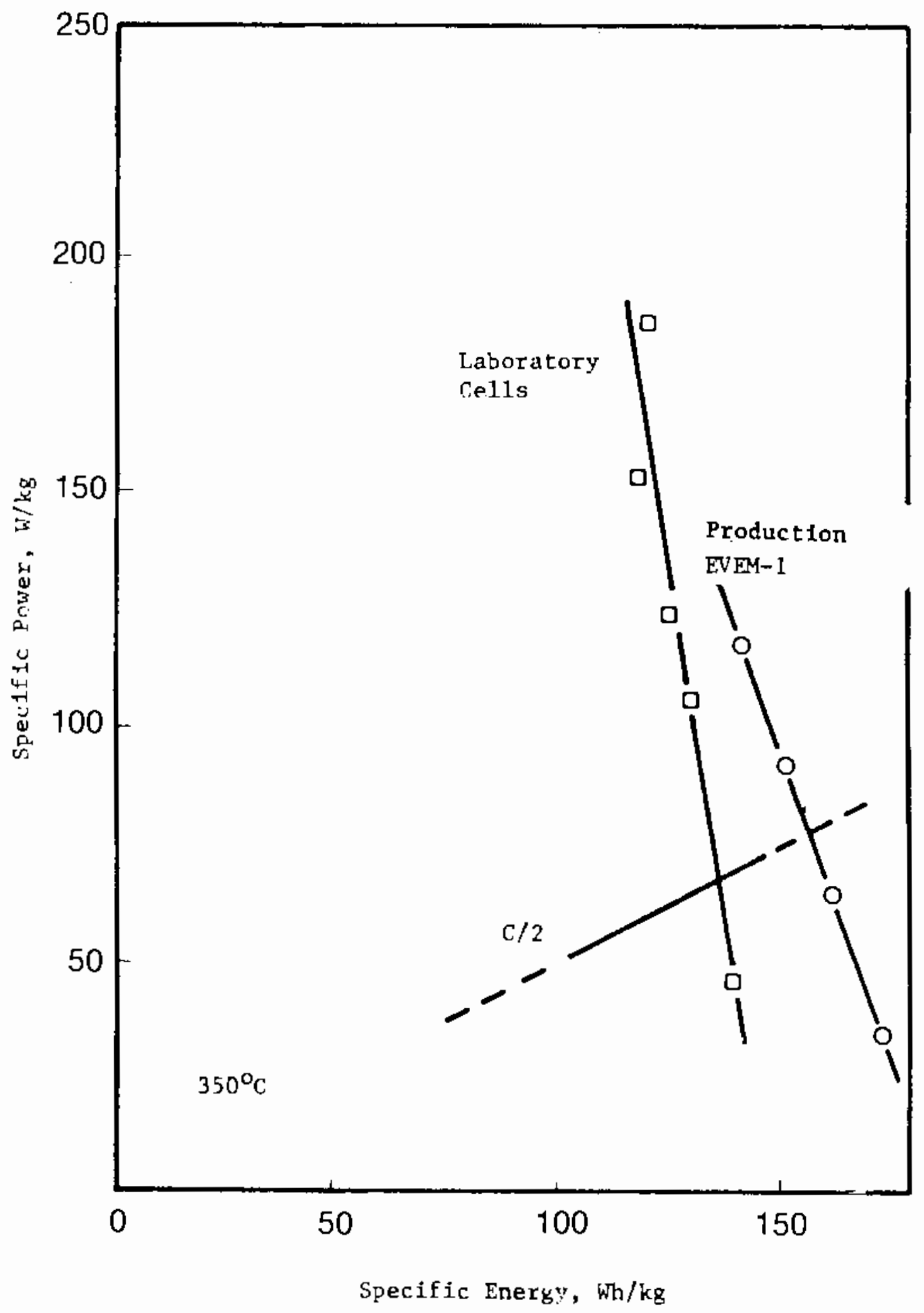

RAGONE PLOT FOR THE NA/S EV CELL FIGURE 10 
TABLE 20

ELECTRIC VEHICLE ENGINEERING MODEL-1 DESIGN COALS

Nominal voltage
Rated capacity
Delivered energy
Peak power ( 30 sec pulse)
Continuous power
Welght
Volume
Thermal loss
LIfe

$240 \mathrm{~V} \mathrm{dc}$

166 Ah at $\mathrm{C} / 3$

$36 \mathrm{kWh}$ at $\mathrm{c} / 3$

$54 \mathrm{~kW}$ at $0-50 \%$ DoD

$44 \mathrm{~kW}$ at $80 \%$ DOD

$16 \mathrm{~kW}$ to $80 \% \mathrm{DoD}$

$402 \mathrm{~kg}$

2831

$300 \mathrm{~W}$ at $350^{\circ} \mathrm{C}$

200 cycles; 1 year

Reference 5 (Harlow) 
The fusing of 1ndividuals cells, reference 4, was found not to be entirely effective because of leakage currents. Modification of the fusing by placing two or three cells in serles with the fuse enables the block1ng of the leakage current. The modifled fusing procedure causes the additional loss of one or two operating cells per fallure. A module contalning 48 parallel units with two cells and a fuse in series ( 96 cell total) has been tested. As of June 1984 the module had undergone 50 dally cycles consisting of:

- 5 hour discharge at $960 \mathrm{~A}$

- 2 hour 1dle period

- 10 hour tapered charge at $<600 \mathrm{~A}$

- 7 hour 1dle perlod

- 7 hour recharge of 83 percent of capacity

- $\quad 76$ percent dc-dc voltage efficiency

- 100 percent coulombic efficiency

The status of the module as of June 1984 was:

- 1 two cell string with torn fuze

- 6 strings with falled cell

- 41 good strings remaining

Test cells have also been constructed with lower cost, pitch-based current collector matrix materlals. These showed excellent performance for test perlods of up to 29 months. Cell testing of a low-cost conductive glass as a cathode corrosion protection coating continued to show promise. (5)

Ceramatec continued to supply the $\beta^{\prime \prime}-a 1 u m i n a$ electrolytes. The location of the Ceramatec facilitles was changed and the new pilot plant facilfties are capable of producing 1500 electric vehicle electrolytes and 1000 load leveling electrolytes ( $500 \mathrm{~mm}$ long) per year. The $\beta^{\prime \prime}$-alumina electrolytes are produced with high densityalumina header rings for cell assembly.

Electrolytes prepared by the lower cost slurry-solution spraydrying process have been produced and tests in Mark-II and EV size cells have been 1nlt1ated. The Mark II cells had completed over 170 cycles, and the EV-size cells had completed 625 cycles as of June 1984 . 


\subsubsection{Beta"-alumina Research}

Research is continuing to better understand the properties of $\beta "$-alumina, the causes for electrolyte tube fallures, and methods for 1mproving the lifetime of the electrolyte.

An Investigation has been inftiated at SNL to provide an independent statistical characterization, establish manufacturing capabilities and tolerance limits, and provide a reference base against which 1mprovements in the $\beta^{\prime \prime-a l u m i n a}$ electrolyte can be compared. (5) The SNL test matrix is shown In Table 21 . It includes both chemical and physical testing at various stages of the process starting from the raw materials to the final sintered body. Propertles are also belng measured at several locations on each electrolyte tube. Sufficient data had not been determined at the time of BECC-6 for statistical analysis.

In addition to studies of the $\beta$ "-alumina electrolytes produced, electrolytes from failed cells are also being examined at SNL. $X$-ray diffraction and surface chemical analysis techniques are to be used in addition to the tests listed in Table 21.

The axlal and radial AC conductivities of the electrolytes are belng determined. The axial AC conductivity is beling measured by using lonically reversible electrodes made from sodium salts. the measurements cover the temperature range 225 to $375^{\circ} \mathrm{C}$. The radial AC conductivity 18 being measured over the temperature range of 25 to $600^{\circ} \mathrm{C}$ by the use of lonically-blocking gold electrodes. Both sets of measurements cover the frequency range from $5 \mathrm{~Hz}$ to $10 \mathrm{MHz}$. The measurements gave a value for the axlal resistance of $\sim 6 \mathrm{ohm}-\mathrm{cm}$ at $300^{\circ} \mathrm{C}$ (Ceramatec value $6 \mathrm{ohm}-\mathrm{cm}$ at $300^{\circ} \mathrm{C}$ ) and the radial resistance of a disc shaped sample (not a part of an electrolyte tube) was $-6 \mathrm{ohm}-\mathrm{cm}$ at $300^{\circ} \mathrm{C}$. The measurements of the axial resistance showed no varlation from the top to the bottom of the electrolyte tube. The tube also had uniform density.

Earlier results of studies by L.C. deJonghe at LBL on the chemical and electrochemical characteristics of $\beta$ and $\beta "$-alumina were sumnarlzed in reference 3 . Additional results have been reported in references 51 and 52 and are included in this summary.

The effect of the mfcrostructure on the 1nitlation of fallure in $\beta$ "-alumina electrolytes was investigated by acoustic emission detection in $\mathrm{Na} / \mathrm{Na}$ cells. Two types of ceramic electrolyte fallures have been 1dentified. The first type, Mode 1 , involves a rapid, catastrophic crack propagation. Mode 1 fallure was described as being lue to the pressure caused by capillary streaming of sodium through a small pre-existing surface flaw on the sodium side of the 
TABLE $2 l$

BETA"-ALUMINA TEST MATRIX

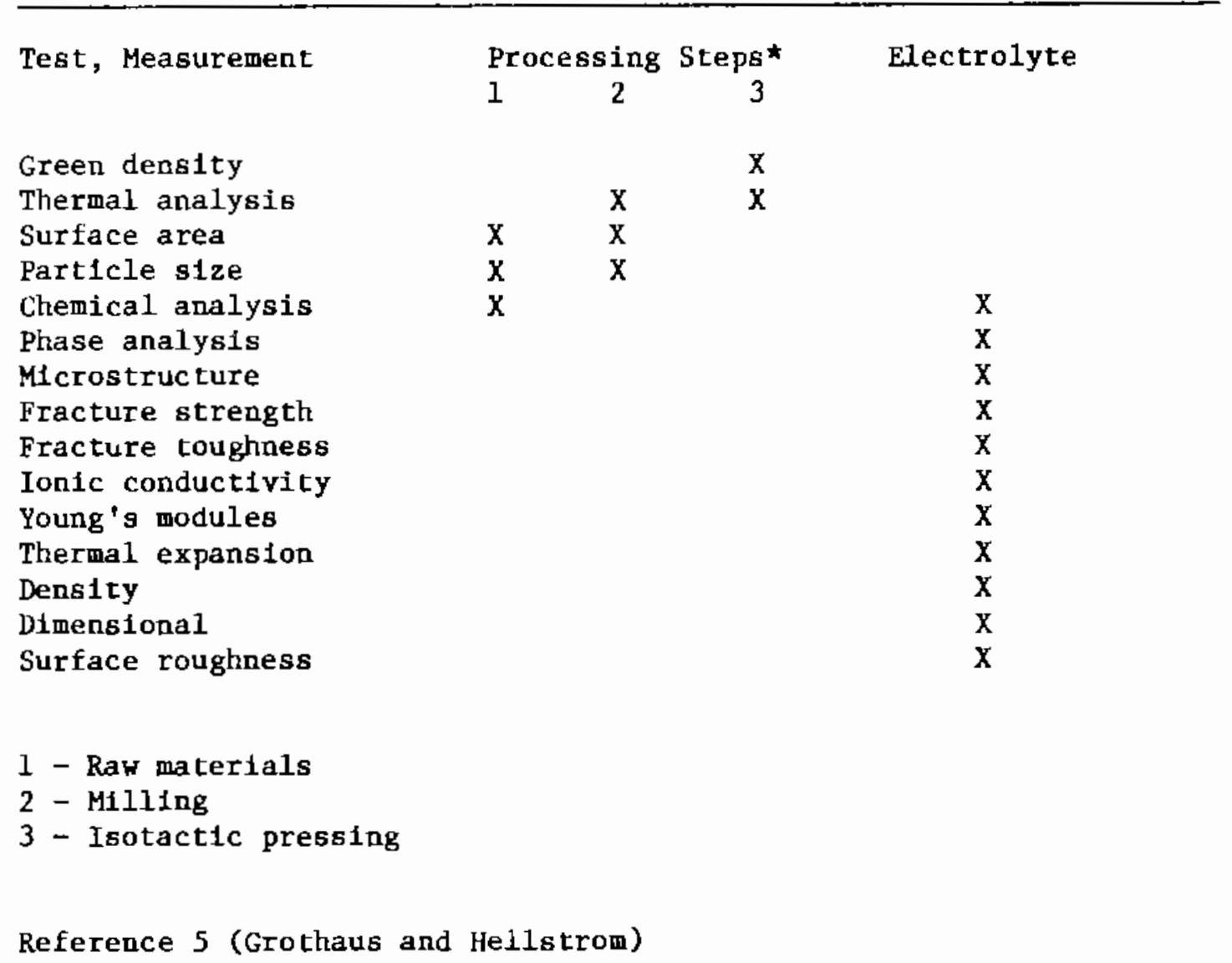


electrolyte. This pressure is caused by crack extension above some critical value of the current density. The observed average critfcal current densittes were 145 and $640 \mathrm{~mA} / \mathrm{cm}^{2}$ for large and for small gralned electrolytes, resp. Micrographs of electrolytes following electrolysis showed preferential degradation along the grain boundartes of large grains, in agreement with the acoustic data.

It is generally agreed that in Mode 1 fallure the critical current density for fallure initiation is proportional to the critical stress intensity factor raised to some power. (52) According to the models, this power has a value of 4 so that the fracture toughness of the electrolyte has a very profound effect on 1ts durab111ty, (53)

Nearly all electrolytes from used $\mathrm{Na} / \mathrm{S}$ cells examined at LBL, showed Mode 1 cracks. This was true even in the case of relatively short use $\left(20 \mathrm{Ah} / \mathrm{cm}^{-2}\right)$. However, such electrolytes operated for extended times with little deterforation in performance. Thus, the exact correlation between Mode 1 crack formation in the laboratory tests and electrolyte fallure in operating cells $1 \mathrm{~s}$ not quantitatively established.

The second type of degradation, Mode II, 1s slow. In several used electrolytes a layer of damage was found to have developed from the sodium side of the electrolyte. The observed damage indicated that a slow grain boundary deterioration was taking place in certain electrolytes. In some cases such layers contalned calcium. This surface damage layer was not universal; some electrolytes used in long-term cell experlments were free of a surface damage layer. These observations sugge日t that subtle compositional differences may have significant effects on the Iffe of the electrolytes.

Evidence also Indicated that slow crack growth had occurred. The evidence included:

- tapered discoloration profiles around the cracks

- morphology of old cracks

- current rate increase dependent critical current density levels

A suggested mechanlsm proposes that the strong reducing conditions, created by the sodiun that is electrolyzed into the crack during cell charging, chemically destroys the electrolyte at the crack tip. This effect has been incorporated into a model which predicts that the electrolyte is falrly unaffected by short current pulses, 
and that a decrease in the current density can Increase the total number of coulombs that a cell can cycle prior to fallure.

Other electrolyte changes observed during the LBL studies Included:

- darkening of solid electrolyte in contact with molten salt

- rapid or slow crack penetration through the electrolyte, causing practical or total short clrcults

- cracking and electrode 1mprinting on the sulfur side of the electrolyte

The chemical coloration was associated with a partial reduction of the electrolyte.

Sulfur-side attack is found frequently in electrolytes that have been used for extended periods in $\mathrm{Na} / \mathrm{S}$ cells. Laboratory experiments have indicated that the polysulfide discharge composition may be very corrosive, espectally if the metal is in equilibrium with solid $\mathrm{Na}_{2} \mathrm{~S}_{2}$. Such conditions can exist locally at the positive side of the electrolyte surface during the discharge cycle.

The fracture toughness of sodium $\beta$ "-alumina crystals was determined by a hardness-indent method. Cracks with habit planes normal to the 00.1 planes had fracture toughness values of -2 $\mathrm{MPa}-\mathrm{m}^{1 / 2}$; cracks running paralle1 to the 00.1 planes had values of $\sim 0.16 \mathrm{MPa}-\mathrm{m}^{1 / 2}$. Th1s extreme antsotropy was considered as partially explaining the difference between calculated and observed critical densitles for Mode I fallure inftiation of polycrystalline solid electrolytes and the variation in fallure initiation from crack to crack.

The efforts at Ceramatec and Rockwell International Science Center on the transformation toughening of $\beta^{\prime \prime-a l u m i n a, ~ r e p o r t e d ~ i n ~}$ reference 4 , has continued. Corporate research at Ceramatec on transformation toughened $\beta^{\prime \prime}-a 1$ umina was reported at BECC-6. Beta-alumina electrolytes, transformation toughened by the addition of zirconfa, have been prepared by the use of the zeta process. Strengths in four-point bending toughness, as indicated through critical stress intensity factors, sodium-ion resistivity, and critical current densities for mechanical fallure have been measured. At around 15 percent zirconta there is an area of overlap of the region of high toughness and the reglon of low resistivity. This overlap region suggests compositions that could be considered for $\mathrm{Na} / \mathrm{S}$ battery application. 
The effort of D.J. Green at Rockwell on transformation toughening of $\beta^{\prime \prime-a l u m i n a ~ i s ~ e m p h a s i z i n g ~ t h e ~ d e t e r m i n a t i o n ~ o f ~ t h e ~}$ optimum zirconia concentration and method of fabrication. (5) The studies on the effect of zirconia concentration have shown that up to $15 \mathrm{v} / \mathrm{o} \mathrm{ZrO}_{2}$ can be added to $\beta "$-alumina without causing a large increase in resistivity. It was also found that with over $10 \mathrm{v} / \mathrm{o}$ $\mathrm{ZrO}_{2}$ grain growth of the $\beta "-a 1 u m i n a$ phase was limited, which helps eliminate fallures caused by the presence of large grains of $\beta^{\prime \prime}$-alumina.

The $\beta^{\prime \prime}-\mathrm{Al}_{2} \mathrm{O}_{3} / \mathrm{ZrO}_{2}$ composites were slip cast from collotdal disperstons of the powders in alcohols, usually 1-butanol. The cast material was sintered at $1535^{\circ} \mathrm{C}$. The resulting ceramic bodies had densities $\sim 97$ percent of theoretical or greater. A comparison of the properties of toughened $\beta$ "-alumina matertals showed that that the fabrication process required careful control. Untform mixing of the two powders and particle size control were 1mportant factors. It was necessary to 11mit the size of the zlrconla particles to one micron. The removal of larger agglomerates from the zirconla was accomplished by sedimentation. On the other hand, 1 t was observed that reduction in the $\beta "$-alumina large particle size content by sedimentation increased the resistivity and large particles gave a more desirable product in terms of ionic resistivity.

Additions of up to 20 percent of tetragonal $\mathrm{ZrO}_{2}$ increased the fracture toughness up to 66 percent with a parallel strength increase of a factor of between 2 and 3. A comparison of the effects of tetragonal and cublc $\mathrm{ZrO}_{2}$ showed that the major strengthening mechanism was the control of the grain-growth of the $\beta^{\prime \prime}$-alumina with the assoclated decrease in critical flaw size. Microstructura1ly, 1t was found that this reduction was a result of the control of the $\beta^{\prime \prime}$-alumina grain size by the zirconia preventing exaggerated grain growth. Th1s eliminated the flaw population assoctated with large gralns of $\beta$ "-alumina which occur in the single phase material.

The addition of 10-20 volume percent of zirconla to $\beta^{\prime \prime}$-alumina gave products with the following properties:

$$
\begin{aligned}
& \text { - fracture toughness - } 3.3 \text { to } 5.0 \mathrm{MPa}-\mathrm{m}^{1 / 2} \\
& \text { - strength - as high as } 440 \mathrm{MPa} \\
& \text { - } \quad \text { Ionic resistivities }\left(300^{\circ} \mathrm{C}\right)-6-10 \mathrm{ohm}-\mathrm{cm}
\end{aligned}
$$

Further Increases in strength are considered to be feastble if further reduction in the relatively large processing flaws can be 
achleved. Recent studies at LBL on zirconla toughened $\beta "$-alumina electrolytes indicated that substantial performance improvement may be expected by zirconta toughening.

\subsubsection{2 $\mathrm{Na}_{2} \mathrm{~S}_{\mathrm{x}} / \mathrm{S}$ Transport Properties}

The knowledge of transport propertles is important to cell performance wodeling. The data on these propertles, which are difficult to measure in the $\mathrm{Na}_{2} \mathrm{~S}_{\mathrm{x}} / \mathrm{S}$ mixture at the cathode, are at best 11mited. John Newman st the University of California, Berkeley has undertaken research to 1mprove the data on the needed transport properties. $(5,7)$

The fundamental transport properties of a multicomponent mixture, the binary transfer coefflcfents, are defined by concentrated solution theory. The mathematical equation relates the gradient of the electrochemlcal potential of a species to the binary transfer coeffictent of this specles with respect to other species in solution. These binary transfer coefficients can, in turn, be related to the conductivities, transference numbers, and diffusion coefficlents determined experimentally as a function of concentration.

The transference number of the sulfur anlons was calculated from 1iterature data. The avallable literature values for diffusion coefficients in sodium polysulfide melts do not agree. This led Newman to investigate restricted diffusion as a method for measuring diffusion coefficlents in sodium polysulfides. Experimentally, the species of unknown diffusivity is placed in a tall thin cylindrical cell, which ts closed at each end by a reference electrode. The potential across the cell is measured as a function of time as the infital sharp concentration gradient is allowed to relax toward a final uniform concentration. At long times, the diffusion coefflclent can be determined from the slope of the logarithmic plot of concentration difference vs. time.

\subsubsection{Corrosion In Polysulf1de Melts}

Corrosion of the cathode current collector is an 1mportant factor in determining the 1ifetime of the Na/S battery. This problem also exists in the $L 1-A 1 / M S_{x}$ batterles when higher valence metal sulfide cathodes are used. This had led to an Intensification of corrosion research related to these systems, with greatest emphasis on the $\mathrm{Na} / \mathrm{S}$ battery positive-current collector. In addition to corrosion resistance, the current collector should have adequate conductivity, imperweability, preferentlal wettabllity by polysulfide rather than sulfur, mechanical stability, and economic vlability. (54) 
A.P. Brown and coworkers at ANL have conducted stat1c corrosion tests of various metals and alloys in sulfur and sodium polysulfide melts. The tests were conducted at $350^{\circ} \mathrm{C}$ with measurements of the reaction kinetics and the Identification of scale morphology.

Nicke1 corrosion showed parabolic kinetics. The corrosion products formed a compact multilayered scale, with composition varylng from the nickel substrate surface to the melt: $\mathrm{NI}_{3} \mathrm{~S}_{2}-$ $\mathrm{N1}_{7} \mathrm{~S}_{6}, \mathrm{Y}_{\mathrm{N} 1 \mathrm{~S}}, \alpha_{\mathrm{N} 1_{1-\mathrm{x}}} \mathrm{S}, \mathrm{N}_{1} \mathrm{~S}_{2}$. The deviation of the corrosion of Iron from parabolic kinetics increased with the basiclty of the polysulfide $\left(\mathrm{Na}_{2} \mathrm{~S}_{3}>\mathrm{Na}_{2} \mathrm{~S}_{4}>\mathrm{Na}_{2} \mathrm{~S}_{5}\right)$. The scale on Iron in the presence of $6 u 1$ fur was $\mathrm{FeS} / \mathrm{FeS}_{2} ;$ in the presence of $\mathrm{Na}_{2} \mathrm{~S}_{3}, \mathrm{Na}_{3} \mathrm{FeS}_{3}$ formed. Molybdenum corroded signiflcantly more slowly than elther nickel or chromium.

Chromium-contalning nickel and 1ron-baged alloys contalning less than 16 percent $\mathrm{Cr}$ corroded $10 \mathrm{Na}_{2} \mathrm{~S}_{3}$. However, when the $\mathrm{Cr}$ content was greater than 20 percent, a protective scale of $\mathrm{NaCrS}_{2}$ formed. Other alloys studied in $\mathrm{Na}_{2} \mathrm{~S}_{3}$ included E-Brite-26-1 (Fe-26 Cr-1 Mo) and nichrome (N1-20 Cr). On the E-Brite, the $\mathrm{NaCrS}_{2}$ scale formed in $\mathrm{Na}_{2} \mathrm{~S}_{3}$ ruptured and spalled due to the dissolution and recrystalization of $\mathrm{Na}_{3} \mathrm{FeS}_{3}$ in the me1t. The scale on nichrome consisted of interwoven layers of $\mathrm{N1S}_{2}$ and $\mathrm{NaCrS}_{2}$. Aluminum and varlous aluminum alloys also showed higher corrosion rates than in sulfur. A binary Al-0.6 $\mathrm{Mg}$ alloy corroded more slowly than pure aluminum in $\mathrm{Na}_{2} \mathrm{~S}_{3}$.

The results of the above corrosion studies, except for the aluminum alloys, are summartzed in Table 22.

Hallna S. Wroblowa and coworkers at Ford Dearborn noted that the obvious cholce of current collector materlala whlch are in contact with the polysulfide melt - metals - are thermodynamlcally unstable in the melt. (54) The only metals that can be used are those that passivate forming more or less protective and conductive layers; such metals include chromium, molybdenum, and tungsten. Aluminum passivates forming an 1nsulating layer. Carbon in most of its forms is too porous. Non-porous glassy carbon ts too expensive even as a thin lining.

The Inftial studies at Ford Dearborn were on chromlum and doped chromium oxides, as well as certaln aluminum composite materials, as positive current collector materlala. $(54)$ These materlals were tested in a laboratory three-electrode glass cell in which the test piece was partly 1mmersed in the sulfur/polysulfide melt and could be polarized using a potentiostat. The rates of chromlum passing into the me1t were meaaured 1 -situ at $350^{\circ} \mathrm{C}$. The experimental parameters included: 
TABLE 22

ANL CORROSION 'I'EST RESULTS

\begin{tabular}{|c|c|c|c|}
\hline Material & Medium & $\begin{array}{c}\text { Penetration after } \\
100 \mathrm{~h} \mathrm{~cm}\end{array}$ & $\begin{array}{c}\text { Parabolic Rate } \\
\text { Constant, cm sec } 1 / 2\end{array}$ \\
\hline $\mathrm{Ni}$ (Nickel-200) & $\mathrm{Na}_{2} \mathrm{~S}_{3}$ & $\begin{array}{l}8.3 \times 10^{-3} \\
7.4 \times 10^{-3}\end{array}$ & $\begin{array}{l}1.38 \times 10^{-5} \\
1.23 \times 10^{-5}\end{array}$ \\
\hline $\begin{array}{l}\text { Fe } \\
\text { (A1Si-1008) }\end{array}$ & $\begin{array}{l}\mathrm{S} \\
\mathrm{Na}_{2} \mathrm{~S}_{3}\end{array}$ & $\begin{array}{l}1.4 \times 10^{-3}(25 h) \\
2.3 \times 10^{-3}(25 h)\end{array}$ & $\begin{array}{l}2.35 \times 10^{-6} \\
\text { Not parabolic }\end{array}$ \\
\hline Molybdenum & 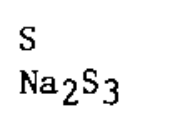 & $\begin{array}{r}5 \times 10^{-6} \\
9.4 \times 10^{-5}\end{array}$ & $\begin{array}{l}\text { Test in progress } \\
\text { Test in progress }\end{array}$ \\
\hline $\begin{array}{l}\text { Hastea } 110 y \mathrm{~B} \\
(\mathrm{~N} 1-28 \mathrm{Mo}-5 \mathrm{Fe})\end{array}$ & $\begin{array}{l}\mathrm{S} \\
\mathrm{Na}_{2} \mathrm{~S}_{3}\end{array}$ & $\begin{array}{r}5 \times 10^{-6} \\
2.4 \times 10^{-3}\end{array}$ & $\begin{array}{l}\text { Not determined } \\
1.52 \times 10^{-6}\end{array}$ \\
\hline $\begin{array}{l}430 \mathrm{SS} \\
(\mathrm{F} \mathrm{e}-16 \mathrm{Cr})\end{array}$ & $\mathrm{Na}_{2} \mathrm{~S}_{3}$ & $1.3 \times 10^{-3}(25 \mathrm{~h})$ & Not parabolic \\
\hline $\begin{array}{l}\text { E-brite } 26-1 \\
(\mathrm{Fe}-26 \mathrm{Cr}-1 \mathrm{Mo})\end{array}$ & $\mathrm{Na}_{2} \mathrm{~S}_{3}$ & $\begin{array}{l}6.5 \times 10^{-5} \\
6.3 \times 10^{-5}\end{array}$ & $\begin{array}{l}\text { Logarithmic } \\
\text { Lfnear } \\
\mathrm{k}=1.9 \times 10^{-10} \\
\text { cn } \sec ^{-1}\end{array}$ \\
\hline $\begin{array}{l}\text { Nichrome } \\
\text { N9-20CI) }\end{array}$ & $\mathrm{Na}_{2} \mathrm{~S}_{3}$ & $2.0 \times 10^{-4}$ & $\begin{array}{l}\text { Linear } \\
\mathrm{k}=7.26 \times 10^{-10} \\
\mathrm{~cm} \sec ^{-1}\end{array}$ \\
\hline
\end{tabular}

Reference 5 (Brown) 
- polarization or cycling conditions

- level of additives to the melt

- plating conditions

The study of the corrosion of chromium involved use of a $\mathrm{Cr}^{51}$ labeled chromium plate on E-brite. The corrosion was measured by determining the increase of radioactivity in the melt as a function of the above noted experimental parameters. Changes in the surface layer were determined by acanning electron microscopy (SEM), electron dispersive $x$-ray spectroscopy (EDAX), and $x$-ray diffraction (XRD). The preliminary results were:

- at chromium potentials above approximately $-0.2 \mathrm{~V}$ ( $\mathrm{Na}_{2} \mathrm{~S}_{5}$ reference) corresponding to $\mathrm{Na}_{2} \mathrm{~S}_{\mathbf{x}}(\mathbf{x}>3)$ the chromium removal rate was 1-5 am per day. The surface was covered with smooth black $\mathrm{Cr}_{2} \mathrm{~S}_{5}$ crystals

- addition of $\mathrm{H}^{+}$and/or $\mathrm{H}_{2} \mathrm{O}$ to the melt did not change the rate of chromium pasaing into the melt

- polarization to a region more cathodic than $-0.2 \mathrm{~V}$, where reduction to $\mathrm{Na}_{2} \mathrm{~S}_{2}$ can occur, was a necessary but not a sufficient factor for inducing higher rates of corrosion

- higher rates of corrosion accompanied by blistering of the surface of the chromium sulfide surface layers occurred only under cycling conditions if the cathodic cut-off potential was lower than $-0.2 \mathrm{~V}$

Chromium oxide is thermodynamically stable in polysulfide melts but 1 a an insulator. By the addition of lower valent dopants, particularly $\mathrm{LI}_{2} \mathrm{O}$ and $\mathrm{MgO}$, materlals with resistivities of less than $i 5 \mathrm{ohm} \mathrm{cm}$ were obtained. Cycling in $\mathrm{Na}_{2} \mathrm{~S}_{x} / \mathrm{S}$ melts of the low resistivity materials caused an increase in resistance which stabilized at $\sim 60 \mathrm{ohm} \mathrm{cm}$. Th1s is sufficlently low to be useable in thin coatings.

Lanthanum chromite $\left(\mathrm{LaCrO}_{3}\right)$ perovskites, subst1tuted with $\mathrm{Sr}$, had initial resistivities of the order of $1 \mathrm{ohm} \mathrm{cm}$ which increased on cycling at a rate of $\sim 7.5 \times 10^{-3} \mathrm{ohm} \mathrm{cm} /$ day. This would lead to a resistivity of less than $40 \mathrm{ohm} \mathrm{cm}$ after 10 years of cycling. No corrosive attack was observed after 6 months of cyclling of doped single or mixed chromium oxidea. Attempts are being made to form coatings of these materlals on stainless steel or aluminum substrates. 
Aluminum, in spite of its formation of a non-conductive coating In the $\mathrm{Na}_{2} \mathrm{~S}_{x} / \mathrm{S}$ melt, was considered of interest as a possible self-healing substrate or in certain composites as the container material. To overcome the problem of the resistivity of the coating formed, Al composites were produced by Imbedding SiC particles into Al alloys. (55) These composites retain their conductivity even after several months of cycling in $\mathrm{Na}_{2} \mathrm{~S}_{\mathbf{x}} / \mathrm{s}$ melts. Optical examination and melt analysis did not reveal corrosive attack on the surface nor along embedded particle-alloy interfaces over a 3 month (450 deep discharge cycles) pertod. The study of these materials under cell operating conditions has been initiated.

Calrns and McLarnon at LBL are investigating the corrosion of $\mathrm{Mo}, \mathrm{Cr}$, and 70 percent $\mathrm{Cr}-30$ percent Fe alloy in molten mixtures of $\mathrm{Na}_{2} \mathrm{~S}-\mathrm{S}$ and $\mathrm{LI}_{2} \mathrm{~S}-\mathrm{S}$. (7) Both static and electrochemical studies are underway. The melt compositions were chosen to reflect expected variations in sulfur activity and were generally within the oinglephase liquid regions. Cross sections of the exposed materla1s were studied using SEM-EDAX techniques to determine the thickness and composition of the scale. Where possfble, weight gain was used to calculate overall corrosion rates.

The electrochemical cell uged was constructed from quartz, a molybdenum feed through was used as a reference electrode, and tungsten springs were used as current leads and to hold the electrodes in place. Tests were conducted by malntalning the metallic samples at a flxed potential relative to a $\mathrm{Mo} / \mathrm{MoS}_{2}$ reference electrode. The cell current and resistance of the scale were measured as a function of time to determine the rate of scale formation. The initial tests showed that Mo was resistant to corrosion at $400^{\circ} \mathrm{C}$ in $\mathrm{LI}_{2} \mathrm{~S}-\mathrm{S}$ melts, apparently independent of sulfur activity. Little specific data could be obtalned on the composition of the film.

\subsubsection{Sodium/trichlorosulfonium Ion Cell}

The research on the chemfstry of the $\mathrm{Na} / \mathrm{SCl}$ cell and 1 ts energy and power characteristics by Mamantov and coworkers has been reviewed in the earlier status reporta, references 1-4. The essential features of this cell are: a sodium negative, a $\beta "$-alumina membrane separator, and tetravalent sulfur in a molten electrolyte of $\mathrm{AlCl} / 3-\mathrm{NaCl}$ as the positive. Like the $\mathrm{Na} / \mathrm{S}$ cell, both the positive and negative reactants are molten. The operating temperature is $180-250^{\circ} \mathrm{C}$.

The emphasis since BECC-5 has been on "sulfur-rich" laboratory cells. A sulfur-rich positive is defined as one in which the S/Al molar ratio is greater than 0.15 . The positive discharges in two oteps, the first representing a four electron change: 


$$
\mathrm{SCl}_{3}^{+}+4 \mathrm{e}^{-} \rightleftharpoons \mathrm{S}^{\mathrm{O}}+3 \mathrm{Cl}^{-}
$$

and the second, a two electron change

$$
\mathrm{S}^{0}+2 \mathrm{e}^{-} \rightleftharpoons \mathrm{S}^{-2}
$$

Several of the cells tested had speciflc energles (active material only) for the total s1x electron change as h1gh as $442 \mathrm{Wh} / \mathrm{kg}$, and for the four electron step of $439 \mathrm{Wh} / \mathrm{kg}$ at $\sim 20 \mathrm{~mA} / \mathrm{cm}^{2}$. Some of these cells were operated at area current densities of $\sim 360 \mathrm{~mA} / \mathrm{cm}^{2}$ showing area power densities in excess of $500 \mathrm{~mW} / \mathrm{cm}^{2}$. In some cells high area energy and area power density were achleved in the same cell. Five cells completed over 100 deep charge-discharge cycles.

\subsubsection{Nove1 Solld Ionfc-Conductor Research}

In addition to the research on $\beta "$-alumina, described in Section 6.3.2.1, the TBR program has been exploring alternative solid lonic conductors. Both ceramics and glasses are being investigated.

The work of B.J. Wuensch at M.I.T. on NASICON $\left(\mathrm{Na}_{1+x} \mathrm{Zr}_{2} \mathrm{~S} 1_{x} \cdot \mathrm{P}_{3-\mathrm{x}_{12}} \mathrm{O}_{12}\right)$ was revlewed in references 2,3 and 4 . The earller structural studies had shown the existence of different sodium-ion sites in the structure. The two sodium-ion sites assisted in the understanding of the conduction vs. composition behavior of NASICON. The observation that the phosphorous in NASICON contributed to its instabllity toward sodium has led to the consideration of the possible synthesis of related structures without phosphorus. The results of these studies have been detalled in reference 56.

Studies of mixtures with the composition of $\mathrm{A}_{2} \mathrm{MSI}_{6}{ }{ }_{15}$ and $\mathrm{A}_{3} \mathrm{M}^{\prime} \mathrm{S1}_{6} \mathrm{O}_{15}$ where $\mathrm{A}=\mathrm{Na}$ or $\mathrm{K}, \mathrm{M}=\mathrm{T1}$ or $\mathrm{Zr}$, and $\mathrm{M}^{\circ}=\mathrm{Y}$, Nd, or La have been inftiated by Wuensch. Crystal structures had previous$1 y$ been determined for individual compositions, $\mathrm{K}_{2} \mathrm{THSI}_{6} \mathrm{O}_{15}$ and $\mathrm{K}_{3} \mathrm{NdSI}_{6} \mathrm{O}_{15}$. These were shown to contain $\mathrm{TIO}_{6}$ or $\mathrm{NdO}_{6}$ octahedra and silicon tetrahedra which bulld a three dimensional system of channels. The alkall tons displayed unusually high thermal motion which may be indicative of high mobility. These systems also have the capability of accommodating cations of different volumes. Th1s in turn permits varlation of the concentration of alkall lons and the fraction of the 1nterstices which are occupled. These compositions thus have a degree of crystal chemical flexibility which is analogous to the NASICON system. (7)

Intial attempts to synthesize the crystalline compounds led to glass formation. The use of high pressure (800-1200 atm) hydrothermal synthesis led to the successful preparation of well 
crystallized powders. The maln product of the reaction was the desired composition, however, also present was a trace of a rare earth oxide. Solid solutions in six glass systems, binary compositions of a member of the $M$ and $M$ ' familles of silicates, were prepared for hydrothermal crystallization. Complex 1mpedance measurements as a function of temperature and frequency for these glasses Indicate activation energies for conduction on the order of 0.7 to $0.9 \mathrm{ev}$ and conductivities at $300^{\circ} \mathrm{C}$ aa high as $10^{-4} \mathrm{ohm}^{-1} \mathrm{~cm}^{-1}$.

Work at Stanford on solld electrolytes, reference 4, has been extended to the preparation of solid solutions of $\mathrm{LI}_{7} \mathrm{TaO}_{6}$ and $\mathrm{LI}_{8} \mathrm{ZrO}_{6}$. These solids are expected to be stable against lithium at unit act1vity. Layered alkali-zirconfum phosphates, $\mathrm{M}_{2} \mathrm{Zr}\left(\mathrm{PO}_{4}\right)_{2}$, were prepared by ion-exchange techniques. It was found that a high temperature modification of the lithium member of this family showed high ionic conductivity, comparable to 1ithium orthosilicate and lith1um orthophosphate, which were discussed in reference 4.

The synthesis of glass electrolytes for possible application in the $\mathrm{Na} / \mathrm{S}$ cell is being carried out at ANL. The efforts on NASIGLAS, glasses with compositions o1milar to NASICON, were described in reference 4. The current 1nvestigations are on soda-rich glasses of the $\mathrm{Na}_{2} \mathrm{O}-\mathrm{ZrO}_{2}-\mathrm{Al}_{2} \mathrm{O}_{3}-\mathrm{S1O}_{2}$ quarternary system. (5) The compositions of interest, in mol fractions, consist of:

$$
\begin{aligned}
& \text { - } \mathrm{Na}_{2} \mathrm{O}-1 / 2 \text { to } 1 / 4 \\
& \text { - } \mathrm{ZrO}_{2}-1 / 6 \text { to } 0 \\
& \text { - } \mathrm{Al}_{2} \mathrm{O}_{3}-1 / 4 \text { to } 0 \\
& \text { - } \mathrm{S}_{2} 0_{2}-1 / 2 \text { to } 1 / 4
\end{aligned}
$$

The properties of 14 glasses of the above compositions are being determined. The propert1es reported at BECC-6.are summarized in Table 23. Glasees with resistivities approaching the goal of 100 ohm-cm are shown. The corrosion of the glasses $1 \mathrm{n} \mathrm{Na}$ and sodium polysulfide-sulfur me1ts is being invertigated.

As an aid in understanding the properties of the glasses and as a guide in selecting new compositions for testing, multiple 1inear regression techniques are belng used to generate response surfaces from the various sets of data. The resistivity response surface Indicated a region of high conductivity and high glass transition

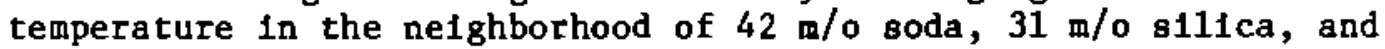
$27 \mathrm{~m} / \circ$ alumina plus $\mathrm{z} 1 \mathrm{rcon} 1 \mathrm{a}$, where m/o is mo1 percent. The presence of glass-forming compositions in this region has been conflrmed and the glass properties are belng investigsted. 
TABLE 23

GLASS COMPOSITIONS AND PROPERTIES

\begin{tabular}{|c|c|c|c|c|c|c|c|}
\hline \multirow[b]{2}{*}{$\mathrm{Na}_{2} \mathrm{C}$} & \multicolumn{2}{|c|}{ Composition, m/o } & \multirow[b]{2}{*}{$\mathrm{Si} \mathrm{O}_{2}$} & \multicolumn{2}{|c|}{ Transition } & \multirow{2}{*}{$\begin{array}{l}\text { Resistivity } \\
\text { ohm-cm at } 300^{\circ} \mathrm{C}\end{array}$} & \multirow{2}{*}{$\begin{array}{c}\text { Activation } \\
\text { Energy } \\
\text { eV }\end{array}$} \\
\hline & $\mathrm{Al}_{2} \mathrm{O}_{3}$ & $\mathrm{ZrO}_{2}$ & & $\begin{array}{c}\text { Temperature, } \\
\text { a }\end{array}$ & $\underset{b}{\mathrm{Tg}-{ }^{\circ} \mathrm{C}}$ & & \\
\hline 0.253 & --- & -- & 0.750 & 468 & 475 & 3704 & 0.684 \\
\hline $0.46 ;$ & -- & -- & 0.540 & 397 & --- & 192 & 0.555 \\
\hline 0.25$)$ & 0.125 & -- & 0.625 & -- & 544 & 3569 & 0.595 \\
\hline $0.25 j$ & 0.250 & --- & 0.500 & --- & --- & 1119 & 0.586 \\
\hline $0.37 \vdots$ & 0.125 & --- & 0.500 & $-\infty$ & 526 & 697 & 0.605 \\
\hline $0.40 ;$ & 0.120 & -- & 0.480 & 501 & 502 & 484 & 0.630 \\
\hline $0.41 \%$ & 0.166 & --- & 0.417 & 540 & -- & 364 & 0.562 \\
\hline 0.37 & -- & 0.125 & 0.500 & $-\infty$ & 645 & 324 & 0.488 \\
\hline 0.41 & -- & 0.083 & 0.500 & 532 & -- & 195 & 0.541 \\
\hline 0.44 & -- & 0.100 & 0.456 & 562 & 564 & 181 & 0.517 \\
\hline 0.461 & -- & 0.110 & 0.430 & 519 & 548 & 144 & 0.507 \\
\hline 0.29 & 0.125 & 0.083 & 0.500 & --- & 685 & 1209 & 0.591 \\
\hline 0.43 & 0.083 & 0.055 & 0.431 & 563 & -- & 162 & 0.522 \\
\hline 0.45 । & 0.062 & 0.042 & 0.446 & -- & 510 & 130 & 0.564 \\
\hline
\end{tabular}

$T g=$, lasa transition temperature

$\mathrm{m} / \mathrm{o}=\mathrm{mol}$ percen $\tau$

$a=1,0 \mathrm{C} / \mathrm{mln}$ temperature rise

$b=2{ }^{\circ} \mathrm{C} /$ min temperature rise

Refer: uce 5 (Roche and Kucera) 
The earlier studies of H.L. Tuller at MIT on various lithlum borate glasses as 1 ithium-ion conductors were reviewed in references 3 and 4. More recent studies have emphasized the relationship between glass structure and ionic conductivity in the system $\mathrm{Na}_{2} \mathrm{O}-\mathrm{NaCl}-\mathrm{B}_{2} \mathrm{O}_{3}$. The activation energles determined for sodium ion conductivity $(-0.035 \mathrm{eV})$ were only slightly larger than those for lithlum ton in splte of the larger size of the sodium lon. Density measurements showed that the sodium Ion was accommodated by dilation. The varfous measurements support the conclusion that conduction in these glasses is domfnated by strain effects on ion mobllity rather than the dissociation of carrier complexes. New glass compositions are belng examined using this guideline.

Major progress has been made in the development of electrochemical cells for the investigation of the corrosion of fast Ion-conductlog glasses in the presence of lithlum. These cells enable the examination of a wide range of 11 thium activities and temperatures. In particular, electrochemical cells of the type:

$$
\mathrm{L} 1-\mathrm{Al} / \mathrm{glass} / \mathrm{L} 1-\mathrm{Sn} / \mathrm{glass} / \mathrm{L} 1-\mathrm{Al}
$$

which include a working and reference cell were used to vary the lithium activity from extremely low values to values approaching unity by the titration of LI from one L1-Al electrode into the L1-Sn electrode.

During continued titration, steps corresponding to the formation of L1-Sn compounds were observed. The relative shift of the position of the steps on the time axis was interpreted as Indicative of lithium reaction with the glasses. This was confirmed by examination of the glass surface. Relationships relating the observed shift to the titration rate and temperature were developed and are being used to derlve chemical diffusion coefficients for LI diffusion into the reaction layers. Glasses with a range of reactivities and effective diffusivities in their reaction layers are being examined. Some of these glasses exhtbit near 1deal electrolyte behavior. 


\subsection{Fue1 Ce11s for Transport}

The studies establishing the technical base and goals for fuel cells for transport have been reviewed in references (3) and (4). As a result of these studies and the evaluation of current and projected performance of ac1d-electrolyte fuel cells, the fuel cell for transport research and englneering program, managed by the Los Alamos National laboratory, was undertaken. This effort is supported by the ECS and EV programs of DOE. ThIs effort is continuing to analyze fuel-cell-vehicle performance projections as an improved guide to establishing fuel-cell technology goals. In addition research is beling conducted on improved reformers for converting fuel, primarlly methanol, to hydrogen for reaction in the fuel cell, 1mproved electrocatalysts, lower-cost long-lived membranes for the solid polymer electrolyte $\left(\mathrm{SPE}^{\mathrm{R}}\right)$ fuel cell, and alternative acid electrolytes.

\subsection{Fue1-Ce11 Technology}

A study at United Technologles Corp. (UTC) was conducted to determine if there is any 1imitation, other than catalyst activity, to the operation of the phosphoric acid fuel cell at low temperature. (5) The benefits to be achieved by low temperature operations include reduced start-up time for the fuel cell and reduced rate of electrocatalyst degradation. The conclusion of the study was, that provided very high cell performance goals can be met, systems can be designed to operate at $65^{\circ} \mathrm{C}$ and meet vehicle requirements. Thus, development of macrocyclic electrocatalysts that can fulfill the low-temperature operating goals becomes an important objective.

The fuel-cell power-plant configuration for automotive load testing and the test procedures for the $20-\mathrm{kW}$ fuel-cell power plant have been developed at I.ANL. An analysis was made of a $20-\mathrm{kW}$ fue1cell powered General Motors X-car on the Federa1 Urban Driving

Schedule (FUDS). The analyals determined the regions of drive-motor torque and speed that best represent the cycle load. A typical test map gave the times of recurrence of torque/speed windows for the FUDS with the fuel-cell power-plant limit and the probable load dynamometer 1fmit. Based on these results, the fue1-cell-powered drive system would be tested at the various torque/speed pointa, and the fuel consumption for the drive schedule determined by weighting each of the test points by its relative duration from the maps. Th1s test procedure corresponds to a standard automotive 1ndustry test procedure for internal combustion engines. 
LANL has designed and assembled a slx station, phosphoric acid, single cell test and measurement system to investigate the effects of rapid current pulsing, slow-load current ramping, and temperature cycling on phosphoric-acid single cells. The cathode reactant for the cells is filtered compressed air. The anode fuel is hydrogen for all stations except station one, where carbon dioxide is added to the fuel stream. All cells are maintained at $200^{\circ} \mathrm{C}$ when under load. As of June 1984, cells 1 and 2 were operating at a constant and continuous $200 \mathrm{~mA} / \mathrm{cm}^{2}$. Cell 3 was being pulsed at a constant and continuous $1 \mathrm{kHz}$ between no-load and $400 \mathrm{ma} / \mathrm{cm}^{2}$ to simulate chopper control. Cells 4 through 6 were being subjected to a varylng current that takes 7.5 seconds to go from no load to 400 $\mathrm{mA} / \mathrm{cm}^{2}$ and returns to no load in 2.5 seconds. Cel1 4 was operating in this mode continuously, whlle cells 5 and 6 were operating in this mode for 3 hours and then left on open clrcult for 21 hours. Cell 5 was being maintalned at $200^{\circ} \mathrm{C}$ during open circult; cell 6 was being allowed to cool to amblent temperature during open circult. This test program was lnitlated as of June 1984 .

The Energy Research Corp. (ERC) is constructing a phosphoric acid fuel cell stack with a methanol reformer that is toprovide a system for establishing baseline fuel-cell performance. $(7)$ The fuel cell and reformer are being sized for a breadboard power plant capable of delivering $20 \mathrm{~kW}$ of continuous output with a transient power capability of $30 \mathrm{~kW}$. The fuel cell stack consists of 200 cells measuring $11 \times 16$ inches ( $28 \times 41 \mathrm{~cm}$ ). A single alr blower provides both cooling alr and process air to the cathode manifold. The stack is designed for a nominal output of 170 amperes at 124 volts. The methanol reformer uses a commercial copper-zinc shift catalyst. The reformer is constructed with a fuel vaporizer and burner, which is housed concentrically within a cylindrical catalyst bed.

The breadboard power plant is controlled manually. Liquid fuel is metered to the reformer at a rate about 1.5 times the stolchiometric-hydrogen requirement based on the reaction:

$$
\mathrm{CH}_{3} \mathrm{OH}+\mathrm{H}_{2} \mathrm{O} \longrightarrow 3 \mathrm{H}_{2}+\mathrm{CO}_{2} \text {. }
$$

Water 1s mixed with methanol at a mole ratio of $1.3: 1$.

To warm the powerplant, 1iquid fuel is burned in the reformer burner, and electrically-heated air is circulated through the cooling-alr loop of the stack. In the normal operating mode, the reformer operates with heat supplied solely by the exhaust tallgas from the fuel-cell stack. 
As of June 1984, the design of the major components had been completed, and the fabrication and assembly of the fuel-cell stack and reformer were underway.

Special emphasis is currently being placed on the solid polymer electrolyte $\left(\mathrm{SPE}^{\mathrm{R}}\right)$ fuel cell which was developed by the General Electric Co. (G.E.). Earlier studies indicated that the SPER fuel cell could become the sole power plant for electric vehicles. However, the current $S E^{R}$ technology is based on Naflon ${ }^{R}$ which 1s too expensive for the cost goals for the EV power plant. The study of the potential applicability and projected capabilities of the $S P E^{R}$ fuel cell was summarized in reference 4.

The effort at G.E. on the SPER fuel cell is centered on the modification of the membrane-catalyst combination in order to reduce fuel cell cost without sacrificing performance. The technology developed at G.E. for the $S \mathrm{SE}^{\mathrm{R}}$-water and brine electrolyzer w111 be transferred to the $S P E^{R}$ fuel cell, where appropriate.

Using the SPER electrolyzer technology as guidance, a baseline SPE $^{\mathrm{R}}$ fuel cell was designed and constructed. This $1 \mathrm{~s}$ shown in cross section in Figure 11. The key to Figure 11 is given in Table 24. The hardware was designed to include low-cost molded carbon collector/separators, carbon-based flow fleld supports, pneumatic bladder stack compression, water cooling, and internal humidification of the process gases. The cell hardware consists of two endplates, six carbon collectors, one bus plate, two copper plates, a bladder, and tie rods. Attached to the cell hardware are quick coupling connectors on the fluid end plate and a valve on the pneumatic end plate.

Several unique features have been incorporated in the cell. One of these resulted in the development of a low cost design incorporating molded carbon/binder collectors. These collectors had been proven in the $S \mathrm{SE}^{\mathrm{R}}$ electrolyzer to be low cost, stable, and manufacturable in large sizes without significant degradation of performance. The stack was designed for humidification of the process gases by water transport through a membrane between two collectors at the end away from the fluid endplate. This facilitates replacement of the membrane and electrode $(M+E)$ without disturbing the humidifer section. The change from stiff endplates to a pressurized rubber bladder for providing the compressive load to the cell improved the uniformity of the compressive loading.

The $\mathrm{SPE}^{\mathrm{R}}$ fuel cell system for laboratory testing was based on a simple modular concept. Results from the earlier automotive fuel cell study dictated a design operating envelope of: 


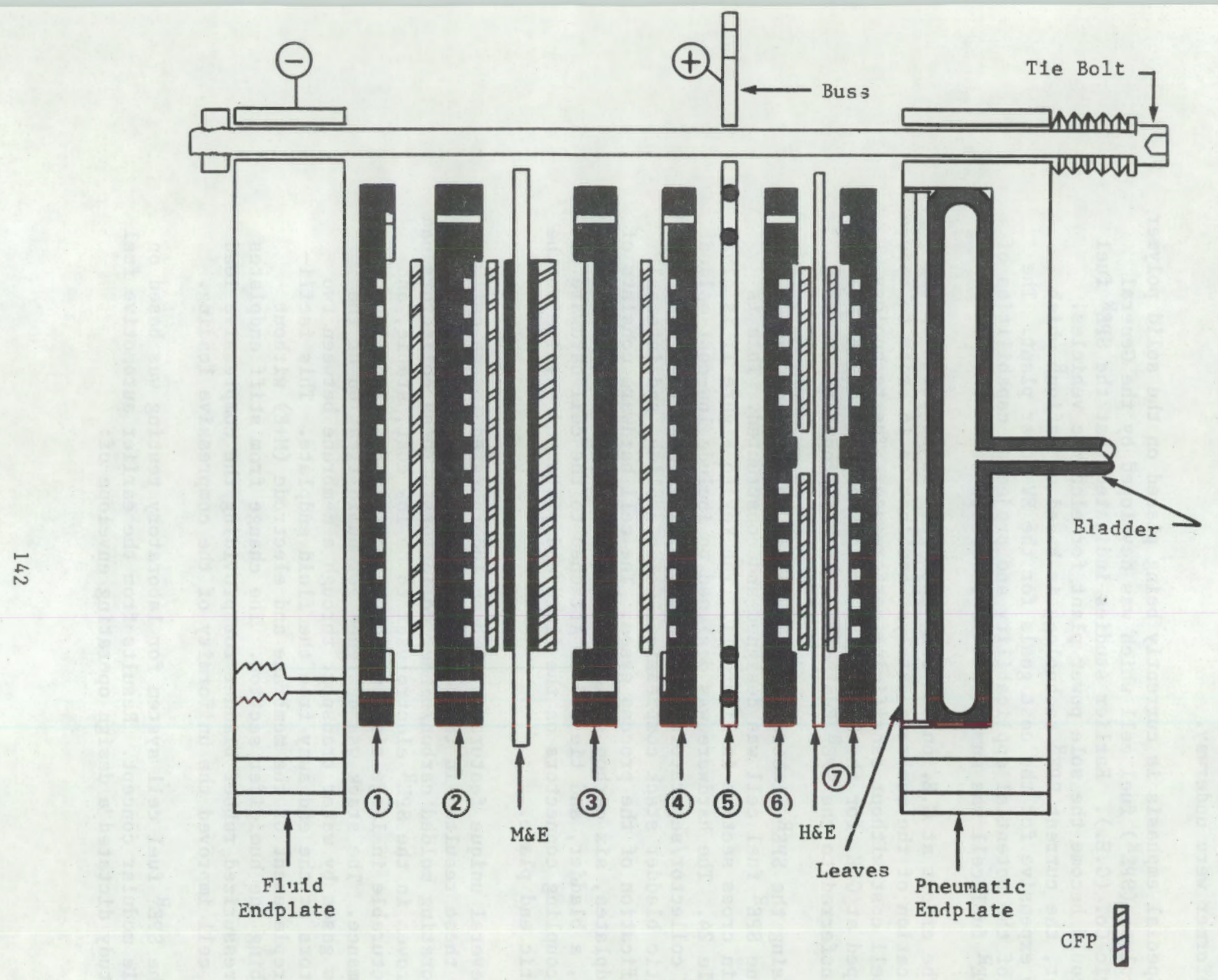

SPE ${ }^{\circledR}$ CELL HARDWARE-CROSS SECTION

FIGURE 11 
TABLE 24

KEY TO FIGURE 11

1. Anode coolant collector

2. Anode collector

3. Cathode collector

4. Cathode coolant collector

5. Positive bus

6. Hum1difler collector - gas

7. Humidifier collector - water

M\&E - Membrane and electrode

H\&E - Hum1d1f1er membrane

CFP - Carbon f1ber paper 
- anode pressures from atmospheric to $30 \mathrm{psig}\left(2.06 \times 10^{2}\right.$ kPA)

- cathode pressures from atmospheric to 135 psig (9.28 x $10^{2} \mathrm{kPA}$ )

- temperatures to $240^{\circ} \mathrm{F}\left(115^{\circ} \mathrm{C}\right)$

- anode feed: pure hydrogen; five gas mixtures of $\mathrm{H}_{2}$ containing $0.17 \mathrm{v} / \mathrm{o}, 0.3 \mathrm{v} / \mathrm{o}, 1.0 \mathrm{v} / \mathrm{o}, 3.0 \mathrm{v} / \mathrm{o}$, or $5.0 \mathrm{v} / \mathrm{o}$ carbon monoxide diluted to $25 \mathrm{v} / \mathrm{o}$ with $\mathrm{CO}_{2}$, remainder 75 $\mathrm{v} / \mathrm{o} \mathrm{H}_{2}$

System controls are included for the following functions:

- heating and cooling

- gas pressure, switching, and flow

- current and voltage

- safety functions

Since the design was for use In a developmental program, the fuel cell hardware can be easily replaced.

It was decided to establish a benchmark performance using baseline membrane and electrode assemblies. The cell operating conditions selected were:

- temperature $-180^{\circ} \mathrm{F}\left(82^{\circ} \mathrm{C}\right)$

- fuel - $30 \mathrm{psig} \mathrm{H}_{2}\left(2.06 \times 10^{2} \mathrm{kPA}\right)$

- oxidizer - $30 \mathrm{psig} \mathrm{O}_{2}\left(2.06 \times 10^{2} \mathrm{kPA}\right)$

- current density - $500 \mathrm{amp} / \mathrm{ft}^{2}\left(538 \mathrm{ma} / \mathrm{cm}^{2}\right)$

- voltage, de $-0.740 \mathrm{~V}$

Twenty five cells were evaluated with baseline membrane and electrode assemblies. The average of these tests was:

$$
\begin{aligned}
& 0.90 \mathrm{~V} \text { at } 100 \mathrm{a} / \mathrm{ft}^{2}\left(108 \mathrm{ma} / \mathrm{cm}^{2}\right) \\
& 0.72 \mathrm{~V} \text { at } 500 \mathrm{a} / \mathrm{ft}^{2}\left(538 \mathrm{ma} / \mathrm{cm}^{2}\right)
\end{aligned}
$$

The G.E. efforts on membranes and electrocatalysts will be discussed with the related investigations on these components. 


\subsection{Methanol Reforming}

Methanol is the concensus fuel for fuel cells for vehtcles. This is due to the avallability of methanol, the projection that methanol will be readily avallable via coal gasification, and the relat Ive ease with which methanol can be converted to hydrogen for reaction in the fuel cell.

At LASL the thermodynamics of methanol reforming was reviewed, The equilibrium calculations showed that carbon monoxide concentrations, even at the lower operating temperatures, should be much larger than those observed. For example, a $1: 1$ stolchiometric mixture of methanol and water at $200^{\circ} \mathrm{C}$ was predicted to yleld a hydrogen/carbon monoxide mixture containing 2.72 percent $\mathrm{CO}$. The experimental results, Los Alamos and others, showed levels of 10 to 100 t1mes lower.

The reaction mechanism for the methanol-water reaction is generally considered as proceeding through a methanol-cracking/ water-gas shift mechanism, two heterogeneous processes. The other published mechanism suggests that steam reforming progresses through a methyl formate step.

The higher concentrations of $C 0$ projected by the crack/shift mechanism made 1 difficult to accept. The methyl formate route was considered to be more reasonable, although the first step involves considerable molecular rearrangement. This rearrangement conflicts with the observed rapld reaction as space velocitles have shown kinetic parameters in excess of $5000 \mathrm{~h}^{-1}$ on Cuo-2no catalysts. There is some agreement that this catalyst involves mlcroclusters of copper dispersed on an oxide lattice.

The technical staff at LANL proposed a model to explain the reaction pathway for methanol reforming on Cu0-zno catalysts. The catalytic site was represented as a $\mathrm{Cu}-\mathrm{Zn}$ site on the surface of the catalyst. The $\mathrm{Cu}-\mathrm{Zn}$ site was assumed to cycle between an oxidized site, stabilized by the interaction between CuO and $\mathrm{ZnO}$, and a reduced site ( $\mathrm{Cu}$ ). It was further postulated that methanol reacted at the oxidized site to form a methoxy adduct, which bonded to the surface with the loss of a hydrogen molecule resulting in a "formyltype" adduct. The remaining carbon-hydrogen bonds are weakened by the interaction of two oxygen atoms with the central carbon atom. After the second hydrogen molecule is produced, the $\mathrm{c} / 0$ spectes left at the $\mathrm{Cu}-2 \mathrm{nO}$ site decomposes to yleld $\mathrm{CO}_{2}$ and a "reduced" reaction site. Finally, water reacts with the reduced site to generate a copper-hydroxy specles that reacts to regenerate the oxidized "entrance" site. The third molecule of hydrogen is produced during this step. Although this mechanism explains 1mportant 
details of the methanol-water reaction further testing is required. The Implication of the model of successive oxidation/ reduction steps is partlally verifled by color changes in the catalyst. The dull green-black color was assoclated with the oxidation step, and the reddish tinge of the fully activated catalyst with the reduction step. Infrared spectroscopy investigations support the proposed reaction pathway. (7)

Closely related studies have been conducted at Brookhaven National Laboratory (BNL). The BNL work has centered on the decomposition of methanol on a clean Pt(111) surface and a Pt(111) surface covered with hydroxyl ions. The technique belng used is high resolution electron energy loss opectroscopy (HRFELS). The HREELS spectra indicated that methanol is firgt chemisorbed on platinum via the oxygen atom, which forms a methoxy linkage with platinum, and the $\mathrm{CH}_{3} \mathrm{O}$ group $1 \mathrm{~s}$ dehydrogenated to a formaldehyde structure. When the last hydrogen atom comes off, the co-remnant turns over and is bonded via the carbon atom to form a platinum carbonyl linkage. Desorption of this group is difficult, and it constitutes the poisoning spectes on platinum. In the case of the hydroxyl-1on-covered surface, the hydrogen adsorbed on the metal reacts with the hydroxyl groups to form water. These experiments were repeated with deuterated methanol, and the results conf1rmed the above conclusions. (7)

Preliminary results Indicated that the adsorption of carbon monoxide differed considerably on clean platinum, platinum covered with adsorbed oxygen, and platinum covered with hydroxyl groups.

A computer code was developed at LANL to a1d in reaction analysis and to predict optimum design of varlous fuel-processing schemes. The code calculates the mass and thermal fluxes through a plug-flow reactor. (5) The model divides the plug flow reactor Into a two-dimensional grid of smaller elements, cells. The code output consists of a listing giving temperature for each radial cell along with average compositions and temperatures for each of the axial cells through the reacting network.

\subsection{Fue1-Ce11 Membrane Research}

The GE approach to developing lower cost membranes was to Investigate commercially avallable materials, purchase samples of selected membranes, and then evaluate both the physical-chemial properties and fuel cell performance-endurance characteristics. (5) Twelve potentlal membrane sources were 1nvestigated; nine looked promising and the manufacturers were contacted. Samples were recelved from four vendors and evaluated for the1s physical-chemical properties. Three of these were operationally evaluated. One of 
the membranes, with a projected cost of one-half that of the present membrane, exhibited performance equivalent to the baseline matertal.

At LANL a model is belng developed that shows the influence of water transport across the membrane on fue1-cell performance. (7) There is strong evidence that membrane transport properties are affected by water interactions and these interactions are partially controlled by polymer structure. In a study of proton-residence times, 1.e., the average lifetime of a proton at a single anionic site, it was shown that proton-residence t1me decreased with increasing polymer equivalent weight. Furthermore, relatively minor changes in polymer structure can substantially influence polymer behavior.

Less has been Investigated regarding the transport properties through lonomer membranes during fuel-cell operations than during electrosynthesis. Although proton fluxes are calculable from known current fluxes, the uniformity of current fluxes is uncertain. Engineering analyses suggested that the apparent water-to-proton ratio involved in the current-driven transport process is 0.6 , this is below the values of 7 to 9 found in other experiments. Thus, water produced at the cathode 18 pumped through an activity gradient and, perhaps, a pressure gradient against the proton flux and concurrent water flow.

The rate of proton transport is determined by the current, whereas the countercurrent water flow is controlled through pressure differences. The water flow is highly influenced by dimensional changes with1n the polymer structure. These changes may, in part, result from the potential gradient that exists between the anode and cathode. At $500 \mathrm{~mA} / \mathrm{cm}^{2}$, the proton flux $1 \mathrm{~s} 5.2 \times 10^{-6}$ moles/ $8 / \mathrm{cm}^{2}$. Water pumped as part of the anodic fuel accounts for only $3.3 \times 10^{-6}$ moles $/ \mathrm{s} / \mathrm{cm}^{2}$. Calculations indicated that dehydration of the anode zone occurred when the water flux decreased below $3.3 \mathrm{x}$ $10^{-5}$ moles $/ \mathrm{s} / \mathrm{cm}^{2}$. The rate of anode zone dehydration increased with Increased current density.

\subsection{New Acid Electrolytes}

The 1nterest in superacid electrolyte fuel cells for $\mathrm{EV}^{\dagger} \mathrm{s}$ to reduce the fuel-cell operating temperature was reviewed in references 3 and 4 . The aclds of greatest interest have been the fluorinated sulfonic acids of which trifluoromethane sulfonic acid (TFMSA) is the first member of the homologous series and disulfonic actds, such as methylene disulfonlc acld and tetrafluoroethylene-1, 2-disulfonic acid (TFEDSA). 
Studies by Calrns, Ross, and McLarnon, LBL, were conducted to characterize TFEDSA as a fuel-cell electrolyte. (7) The kinetic currents for oxygen reduction in TFEDSA and TFMSA were measured using rotating disc experiments. The two acids showed similar behavior at $\mathrm{pH}=1$. The reaction order with respect to oxygen concentration was measured in both electrolytes by using gases with varlous partial pressures of oxygen. The reaction order in both electrolytes wss unity. Additional studies on a1ternative electrolytes are being supported by the fuel cell program of the Office of Fossil Energy, DOE.

\subsection{Fue1-Ce11 Electrocatalys1s}

The major effort for the advancement of fue1-ce1l technology has been on Improved electrocatalysts for the oxygen electrode. The cost and 11fetime of the catalyst in acld fuel cells, emphasized in this and the stationary fuel-cell program, is a determining factor in the commerclalization of fuel cells. Therefore, electrocatalysis has been an area of research emphasis. Work is also being conducted on $\mathrm{CO}$ tolerant anode catalysts. Electrocatalysis in alkaline media was discussed in reference to the $1 \mathrm{ron} / \mathrm{a} 1 \mathrm{r}$ and aluminum/a1r batterfes in Sections 4.2 and 4.3. The LANI program Includes investigattons ranging from the performance testing of specific anode catalysts to quantum mechanical calculations of the oxygen/catalyst interactions. The program also includes the investigation of the mechanism of the electrocatalysis of oxygen reduction and new electrocatalysts.

G.E. Is conducting a two-pronged approach to the improvement of the carbon monoxide tolerance of anode catalysts:

- reduction of catalyst cost by the reduction of catalyst loading

- 1mprovement of catalyst performance with hydrogen fuel contalning carbon monoxide

Four Co tolerant anode catalysts (designated A, B, C, and D) were prepared based on previous developments. A was selected a the baseline anode catalyst. Later two more catalysts, designated $\mathrm{E}$ and F, with slightly different compositions were prepared. Various methods of catalyst preparation were also investigated. Although all the anode catalysts showed CO tolerance, catalysts $\mathrm{E}$ and $\mathrm{F}$ showed exceptional tolerance. Two of the anode catalysto, not opecifically designated, were reported to show supertor performance In the presence of I percent Co. Catalyst loadings at both the anode and cathode were reduced 50 percent with some loss in cell performance. 
John A. S. Bett at UTC has also been exploring anode catalysts for increased $\mathrm{CO}$ tolerance, which would enable lower anode operating temperatures. Past experfence has shown that the anode catalyst used in the phosphoric fuel cell becomes more co tolerant with increasing temperature. Based on the results of previous UTC efforts and a 1iterature study, the following were selected as candidate anode catalysts: gold/platinum, plat1num/ruthenium, platinum/bismuth, and three platinum-based UTC proprletary catalysts CSV-11, CSV-15 and CSV-36. The electrodes were tested at 100,140 and $170^{\circ} \mathrm{C}$ in phosphoric acid with a dew point of $-57^{\circ} \mathrm{C}$.

The performance of the anode catalysts was evaluated by determining the 1ncrease in the polarization of a pure hydrogen anode on switching from pure hydrogen to fuel gas contalning one percent $\mathrm{CO}$. At $180^{\circ} \mathrm{C}$, the $\mathrm{CO}$-tolerance of $\mathrm{Pt}$ was superior to any of the candidate catalysts. CSV-11 and CSV-15 showed a clear advantage over $\mathrm{Pt}$ at 100 and $140^{\circ} \mathrm{C}$. Au/ $\mathrm{Pd}$ and $\mathrm{Pt} / \mathrm{Ru}$ showed no advantage over platinum. The performance of CSV-1l at $140^{\circ} \mathrm{C}$ showe promise of satisfying the vehicle goals. This finding led to a shift in emphasis to the development of low temperature cathode catalysts, primarily metal ligands, for use with CSV-1l.

At LANL a sensitive experimental technique was developed by S. Gottesfeld for determining the effect of anton adsorption on the pseudocapacitance for the oxide-formation reaction of a gold ourfase. Quantitative data was obtained on the adsorption of $\mathrm{HSO}_{4}, \mathrm{H}_{2} \mathrm{PO}_{4}$, and $\mathrm{CF}_{3} \mathrm{SO}_{3}$ on gold. Substantlal adsorption of $\mathrm{HSO}_{4}$ and $\mathrm{H}_{2} \mathrm{PO}_{4}$ was observed, but the extent of $\mathrm{CF}_{3} \mathrm{SO}_{3}$ adsorption was minimal in the potential range studied. Rotating ring-disc electrode measurements in $0.05 \mathrm{M} H F$ showed that $\mathrm{HSO}_{4}$ adsorption decreased the oxygen reduction kinet1cs, but $\mathrm{H}_{3} \mathrm{PO}_{4}$ or $\mathrm{CF}_{3} \mathrm{SO}_{3}$ lons did not. The effects on the kinetics were nore pronounced when $\mathrm{Cl}^{-}$or $\mathrm{Br}^{-}$was adsorbed.

The electrochemistry at the interface between the solid polymer electrolyte $\left(\mathrm{Naflon}{ }^{\mathrm{R}}\right.$ ) and varlous electrodes has been investlgated at BN... (5, 7$)$ The electrode materials included platinum and gold scree:is in direct contact with $\mathrm{Naflon}^{\mathrm{R}}$. Additional experiments were iarried out on multiple combinations of platinum screens with elther graphite felt or gold screen electrodes with only one of the electrodes in direct contact with the membrane. The goal of the experiments was the better understanding of the current generation mechanfsm and the factors controlling catalyst utilization at electrodes in contact with an lonic solld polymer. The measurement technique was cyclic voltametry.

The voltammograms were determined for the electrodes in contact with $\mathrm{Naflon}^{\mathrm{R}}$ and $\mathrm{In}$ an aqueous acld. In the case of the platinum and gold screens, these were very simflar. The adsorption doubled

(a) McBreen, J., "Voltamelric Studies of Electrodes in Contact with Ionomeric Membranes" submitted for publication. 
In the presence of a second screen which was not in direct contact with the Nafion ${ }^{R}$. This indicated that the electrode remote from the lonic polymer was electrochemically active. When the gold or graphite electrodes were between the platinum screen and the Nafion, there was a considerable distortion of the platinum oxide reduction peak and the hydrogen adsorption and desorption peaks. Th1s was consistent with a resistive path. There was no affect on the gold electrode upon the interposition of a platinum screen. The results infer that the platinum black catalyst used in the SPE ${ }^{R}$ fuel cell should have high utillzation and that the 1ncorporation of platinum in carbon, not practiced, would decrease cell performance.

There is being developed at LANL an in-situ fon beam-analysis technique to characterize electrode surfaces under conditions closely approximating a working electrochemical cell. To accomplish this a cell was designed and constructed with a thin platinum film sealing a small window and serving as the working electrode. The incldent Ion beam is to penetrate the platinum and scatter from the chemical spectes on the electrolyte side of the film electrode. A 1 m thick sputtered-platinum film was successfully placed over the window of the electrochemical cell. Electrochemistry was performed In the cell. The thickness of the platinum was such that the platInum signal partially obscured other signals. A platinum $\mathrm{film} /$ inert substrate is being fabricated that will allow better signal resolution and allow the cell bean aperture to be larger.

Supplementing the attempts to develop techniques for the direct determination of species on platinum surface is the recently LANL initlated ab inftio quantum mechanical calculations of the structure of Pto. This molecule was selected as it is the simplest, in terms of composition, of the possible species which can be formed between platinum and oxygen. This is considered to be an important step in understanding the platinum-oxygen-water interactions at platinum catalyst surfaces.

Electrocatalysis at nearly ordered metallic surfaces is being Investigated by Ross at LBL. Surface-analysis technlquess such as low energy electron diffraction (LEED), are belng used. (58) A LEED apparatus has been interfaced directly with an electrochemical cell to determine which metal/metal oxide or $\mathrm{Me} / \mathrm{Me}^{2+}$ systems can be emersed and examined in the metallic state. Gold, copper, and platinum were shown to be compatible with this technique whereas zinc causes a problem because of its reaction with afr during emersion/evacuation.

$\mathrm{Pt} / \mathrm{PtO} \mathrm{x}_{\mathrm{x}}$ was selected for extensive study. A LEED analysis of the (100) surface Indicated that cycling can alter the long-range ordering $(-10 \mathrm{~nm})$ of the surface, but local order $(1.3-1.9 \mathrm{~nm})$ is 
always preserved. Cycling between the hydrogen adsorption region and the edge of the oxygen electrosorption region ( $0-0.83 \mathrm{~V}$ vs. RHE) caused no discernible change in the Pt(100) LEED pattern. Cycling Into the oxygen electrosorption regton ( $1.58 \mathrm{~V}$ vs. RHE) produced LEED patterns characterized by alternate broadened and sharp spots. The filuctuation of the spot breadth with incident electron beam energy was consistent with the formation of a correlated island-hole structure. (59)

The restrictions 1mposed by the LEED system on cell geometry make it necessary to use transient methods with stationary electrodes to study the kinetics of the $\mathrm{Me} / \mathrm{Me}^{\mathrm{Z}+}$ reaction and for the dissolution of atomic scale quantities of metal. A mathematical description of voltammetric curves for reversible metal deposition/ dissolution was developed and confirmed using the $\mathrm{Ag} / \mathrm{Ag}^{+}$electrode. Preliminary experiments on copper deposition from dilute acidic $\mathrm{Cu}^{2+}$ solution indicated that LEED can be used to determine atomic-scale structural transformations that accompany the $\mathrm{Cu} / \mathrm{Cu}^{2+}$ reactions during potential cycling of the substrate. $(59)$

Jeffery T. Glass and coworkers, Untversity of Virglnia, are investigating the effects of various metallurgical variables on the electrocatalysis of the oxygen reaction. The effort has been subdivided into four phases:

- study the effect of increasing Cr content, and therefore decreasing lattice spacing, on the catalytic properties of $\mathrm{Pt}-\mathrm{Cr}$ alloys within the Pt-rich terminal solld solution

- examine the effect of the order-disorder transition within the Pt-rich solid solution on catalysis

- study the differences between the intermetallic and solid solution phases in both their activities and stabilities

- determine the effect of dispersion within a matrix phase and the effect of metastable structures through the study of varlous heat treatments of samples consisting of two phases when in equilibrium.

Elght Pt-Cr alloy specimens of appropriate composition have been selected to cover the four phases of the study. To date, three of the elght spectmens and pure $\mathrm{Pt}$ and $\mathrm{Cr}$ have been furnished for this research by James $\mathrm{L}$. Smith at IANL. The specimens have been sectioned and metallographically pollshed for metallurglcal characterlzation. Lattice parameters were measured via $x$-ray diffraction and structures were determined by comparison with standard $x$-ray data. Microscopy following chemical and electrochemical etching was 
being conducted (June 1984) to document grain sizes and to look for impurities, such as oxides, in the specimens.

The free energies of $\mathrm{Pt}-\mathrm{Cr}$ alloys, as well as those of alloys of Pt-T1, Pt-Zr, and Pt-V, were calculated. These free energles gave data on the relative stability of the different alloys. According to these calculations, $\mathrm{Pt}-\mathrm{Cr}$ and $\mathrm{Pt}-\mathrm{Zr}$ had the highest negative free energles and were the most stable with respect to the alloying agents. The most stable composition for this group of a1loys was at approximately 50 atomic percent. The applicability of these results to a fuel-cell system are to be tested by electrochemical studies of the stability of the Pt-Cr alloys.

Studies are in progress at UTC and BNL on the use of meta1macrocycllc ligands as catalysts or as catalyst sources for the oxygen electrodes. Related studies at Case Western Reserve and ELTECH were summarlzed In Section 4.3 as part of the review of the Al/alr battery. The major difference is that the fuel cell research activities emphasize acid systems and the metal/air batterles, alkaline systems.

Bett at UTC is 1nvestigating thermally decomposed cobalt and Iron macrocyclics as electrocatalysts for the oxygen electrodes for phosphoric actd fuel cells. The macrocycles ligands include phthalocyanines, tetraazaannulenes (TAA), and tetramethoxy pheny1 porphyrins (TMPP). These are being investigated to:

- 1dentify the catalyst with the highest intrinsic activity

- Identify factors 11miting catalyst performance in fuel-cell electrodes

- develop approaches for the 1mprovement of catalysts prepared from metal macrocyclics

At UTC a large matrlx of catalyst preparation and test varlables has been investigated to determine factors influencing catalyst and electrode performance.

Several different carbons were selected as catalyst supports. These Included Vulcan XC-72; Black Pearls-2000, a h1gh-surface-area carbon; and RB carbon which had been used at Case Western Reserve Untv.

Supported CoTAA, thermally decomposed at $700^{\circ} \mathrm{C}$, gave well defined Tafel behavior in cathodic polarization, with performance reflecting the intrinsic activity of the pyrolyzed macrocyclic compound. FeTMPP gave even higher performance than CoTAA at low 
current density but with pronounced curvature of the polarization curve at high current density. The 1ntrinsic activity of FeTMPP exceels that of platinum in the temperature range chosen. The performance of FeTMPP catalyzed electrodes at h1gh current density appeared limited by reactant gas diffusion and by 1onic conductance in the electrolyte-filled porous structure. Improvement in these factors by modification of the support and control of pyrolysis conditions are considered by Bett to be approaches to achieving the performance goals for EV fuel cells.

At BNL several metal tetrasulfonated phthalocyanines (MTSP) were prepared 1ncluding those of $\mathrm{Mn}, \mathrm{Cr}, \mathrm{vo}^{+2}, \mathrm{Fe}$ (III), $\mathrm{Fe}$ (II), $\mathrm{Co}, \mathrm{N} 1, \mathrm{Cu}, \mathrm{Zn}, \mathrm{Ga}, \mathrm{Rh}, \mathrm{Ir}$, and the demetalated tetrasulfonated phthalocyanine. The evaluation process consisted of $\mathrm{H}_{2} \mathrm{O}_{2}$

decomposition studies, Investigation of the interaction of oxygen with the MTSP compounds, and a detalled screening of these materlals as electrocatalysts for fuel-cell reactlons. Preliminary $\mathrm{H}_{2} \mathrm{O}_{2}$ decomposition studies were carried out with the both the MTSP and the $\mathrm{H}_{2} \mathrm{O}_{2}$ in dilute solution, $10^{-5} \mathrm{M}$ and $5 \times 10^{-4}-2 \times 10^{-3} \mathrm{M}$, resp. All of the above 11sted MTSP's, except those of $\mathrm{Rh}$, Ir, and $\mathrm{H}_{2}$ TSP, were evaluated. The MTSP compounds of Mn, $\mathrm{Fe}$ (II), $\mathrm{Fe}$ (III), $\mathrm{Ru}$, and Co interacted strongly with $\mathrm{H}_{2} \mathrm{O}_{2}$, decomposing both the $\mathrm{H}_{2} \mathrm{O}_{2}$ and the MTSP. The reactivity was apparently metal center dependent. There was also good correlation between the d-electron population at the metal center and the sensitivity toward hydrogen peroxide. The d-electron population also correlated well with the activity of the MTSP as an electrocatalyst for oxygen reduction. The work indicates that the MTSP compounds catalyze oxygen reduction because they can axially coordinate $\mathrm{O}_{2}$ and $\mathrm{H}_{2} \mathrm{O}_{2}$. Sultable metal centers can donate electron density to encourage heterolytic change of oxygen.

Exploratory studies were conducted on the electrocatalytic activity of CoTSP incorporated in polypyrrole films. The polypyrrole f1lms were prepared by electrodeposition from an aqueous solution of pyrrole and CoTSP. The CoTSP acted as the counter ion in the film. The catalytic performance of these films was better than that reported for adsorbed macrocyclics on carbon. 


\subsection{Electrochemical Engineering and Technologies}

\subsection{Electrochemical Englneering}

The ECS supported studies of the electrochemlal engineering of Industrlal electrochemical processes, lncluding performance modeling of speciflc battery systews, has decreased along with the efforts on battery commercialization and energy conservation in electrochemlcal process Industries. The ECS program is continuing support of studies in generic electrochemical engineering for batterles, electrolytic cells, and other electrochemical technologies.

The Inftiation of atudies by Selman, IIT, of the literature on experimentally-established mass- and heat-transfer correlations for the design of electrochemical systems was noted in reference 4. The search for, and compllation of, heat-and mass-transfer correlations In the 11terature have been completed. The correlations were collected from 33 journals and 13 standard textbooks or reference volumes. Approximately 420 mass-transfer correlations from 260 sources and 450 heat-transfer correlations from 240 sources were complled. All correlations have been classifled using a 13-digtt decimal classification according to flow contalnment, flow regime and flow geometry, type of convection, transfer surface geometry and motion, and heat-transfer medium. The MIDAS data-acquisition system was uaed for data storage and retrieval.

A final draft report has been written. The draft report has been revlewed by several experts in fundamental and applied mass and heat transfer. The reviewed correlations wll be published as a DOE-LBL report, as part of a professlonel journal, or as a chapter In a book.

Newman at the University of Calffornla, Berkeley is Invest1gating methods for the design and scale-up of battery systems, analysis of thin-gap flow cells, and porous flow-through and flow-by electrodes. The overall objectives of this investigation are:

- to Improve the performance of electrochemical cells used in the inter-conversion of electrical and chemical energy

- to develop mathematical models to predict the behavior of electrochemical systems and to Identify Important process parameters

- to experimentally verify the completeness and accuracy of the models 
Experimental data for one-dimensional porous battery electrodes were combined with a model for the current and cell connectors to predict specific energy and maximum power for complete battery systems. The discharge behavior of the plate, including electrochemical and grid resistances, were combined with the voltage and weight penalties of the interconnecting bus and post, positive and negative active materials, and other cell components to give specific results for the $\mathrm{LI}-\mathrm{Al} / \mathrm{FeS}$ battery. These results can be used to optimize the battery for maximum energy or power, or a compromise design may be selected.

The use of porous flow-through electrodes for the electrolytic removal of small amounts of lead was selected as a model system for evaluating the porous electrode model. Experimental data were obtalned on the removal of lead at a concentration of $4 \mathrm{Hg} / \mathrm{cm}^{3}$ from a $1 \mathrm{M} \mathrm{H}_{2} \mathrm{SO}_{4}$ feed stream in atmospheric and high pressure flow through reactors. The atmospheric reactor used reticulatedvitreous carbon that was coated with a mercury f11m. The best results showed removal of 98 percent of the lead from the feed stream. In the high-pressure experiments, pressures were varied up to 120 bars on electrode beds of copper- or lead-coated spheres. The copper spheres showed high rates of hydrogen evolution which inhibited lead deposition. The use of lead spheres inhibited the hydrogen evolution which had inhibited lead deposition. This inhibition often resulted in the formation of $\mathrm{PbSO}_{4}$ layers.

A limiting-current model for the potential and concentration distribution for a flow-by electrode was developed. The model showed that for flow-by electrodes, the maximum solution-phase potential drop is dependent upon one relevant parameter: the product of the electrode width and the reciprocal of the penetration depth.

Design equations were also derived which related the fixed and variable costs to electrode design and operating variables. The sum of flxed and varlable costs were then optimized for the flow-through and flow-by configurations to give the conditions under which each configuration is preferred.

Toblas at LBL has developed a novel approach to the understanding of gas evolution at electrodes, 1.e., the use of a micro-mosalc electrode which $1 \mathrm{~s}$ described in references 5 and 60 . This electrode, which was prepared from a sllicon wafer using integrated-circuit manufacturing technology, consisted of a $10 \times 10$ matrix of coplanar, electrically 1solated, square platinum segments on 100-micron centers surrounded by a relatively large buffer segment. A computer-activated data acquisition and control system was assembled. The software was developed to monitor the current to 
each Indiyidual segment and to control the potential of selected segments. (61)

The classical Iimlting current method was employed in performing mass transfer rate experiments in free convection, and later, to determine the effects of bubble separation and coalescence. Following a potential step, in the absence of bubble phenomena, the current to each segment of an electrode facing upward decreased inversely proportionately to the square root of time. However, 15-20 seconds after the potential step was applied, the fluld next to the electrode became less dense and convection was inftiated.. A stable perlodic current developed. The amplitude of the current fluctations at a single segment of the mosalc electrode was greater than the average fluctations over the total aurface.

The micro-mosaic electrode, orfented horlzontally and facing upward, was used to measure the effect of the disengagement of a single hydrogen bubble, and of the coalescence of two bubbles, on the limiting current of the reduction of ferric to ferrous lons. (62) The mass-transfer enhancement due to bubble disengagement was found to be small when compared to that due to coalescence. Increases in the mass-transfer rate of more than an order of magnitude over the free convection limiting current were observed for the coalescence phenomena. The development of a theoretical model of the phenomena involved has been inftiated. The direction of the initial change in the limiting current was correctly modeled by the numerical solution of the convectivediffusion equation. This equation was derived for the flow generated by an ascending fluld sphere near a horlzontal surface and for the flow in the wedge formed by the electrode and the bubble in the regton near the collapse of the bubble contact area.

Observations of the growth and detachment of single bubbles by means of high speed motion plctures revealed that for large bubbles (d > Imm) the time scale for the collapse of the contact area is in the order of milliseconds. Numerically 1mplemented solutions of the Laplace-Young equation ylelded the shape and maximum bubble size attalnable on flat and curved surfaces. A correlation was developed to relate maximum bubble volume to angle of contact, surface tension, and radius of curvature of the surface.

The current distribution in the vicinity of a single attached bubble was computed by the use of the finite element method. $(5,7)$ In addition to the ohmic and kinetic effects, the anaylsis included the transport of the dissolved gas spectes and the contribution of the supersaturation to concentration overpotentlal. It was found that the famillar effect of ohmic obstruction by the bubble could be greatly overshadowed by the localized lowering of the concentration 
overpotential. The result showed an enhancement rather than a depression of current density in the "shadow region" under the bubble. The magnitude of this effect depended on average current density and the thickness of the mass-transfer boundary layer.

\subsection{Electrochemical Technologies}

The background for the 1nvestigation by Sadoway on the effect of 1mpurities on the electrowinning of magnesium was summarized in reference 4. The 1mpurtties selected were boron and sulfur as these are known to require careful control in 1ndustrial magnesium cells. The electrolyte used in the investigations corresponded to that used Industrially in the "anhydrous" electrolytic processes (10 w/o $\mathrm{MgCl}_{2}, 10 \mathrm{w} / 0 \mathrm{CaCl}_{2}, 20 \mathrm{w} / \mathrm{o} \mathrm{KCl}$, and $\left.60 \mathrm{w} / \mathrm{o} \mathrm{NaCl}\right)$. The effects of boron and of sulfur were studled by the addition of $0.5 \mathrm{w} / \mathrm{o}$ boron as $\mathrm{B}_{2} \mathrm{O}_{3}$ or $0.5 \mathrm{w} / 0$ sulfur as $\mathrm{MgSO}_{4}$, resp.

With electrolytes that were contaminated with $B$ or $S$, galvanostatic electrodeposition occurred at voltages too low to produce magnestum metal. Instead, what appeared to be nonmetallic deposits plated out on the cathode. In the case of the boron Impurity, ESCA elemental analysis showed that the cathodic deposit formed contalned some of the boron. The results were consistent wth the presence of magnestum borlde, magnestum oxide, and magnesium hydroxychloride. It was also proposed that the sodium in the deposit was present as $\mathrm{Na}_{2} \mathrm{O}$ or magnesium sodium borlde. The latter is in accordance with literature suggestions.

In the case of a sulfur source as the 1mpurtty, extssion spectrography and infrared analysis of the cathodic deposit were consistent with the formation of magnesium oxide and magnesium sulfide. In elther case, $B$ or $S$ contamination, the cathode surface becomes passivated by the formation of magnesium compounds.

The use of paired electroorganic synthesis, 1.e., the simultaneous production of useful organic products at the anode and cathode of an electrolysis cel1, was reviewed in the preceding status report, Reference 4. This gave the background for the investigation of the reduction of glucose to sorbitol and 1ta oxidation to gluconlc acid in a single cell. The previously reviewed investigations, conducted by M.M. Ba1zer and coworkers, showed that by the use of a zinc-amalgam $(\mathrm{Zn}(\mathrm{Hg})$ ) cathode and the electrochentcal generation of HOBr as an oxidant at the anode, the destred objective could be fulfilled. The earlier experimenta helped define the following reaction conditions:

- $\quad \mathrm{pH} \mathrm{5-7}$ to minimfze glucose 1somertzation 
- temperature $55^{\circ} \mathrm{C}$ to rinimize the parasitic E-gluconolactone/glucose redux couple

- supporting electrolyte of $\mathrm{CaBr}_{2}$ to facilitate the separation of products and reactants

The current efflciency for the oxidation of glucose to gluconic acid was 100 percent but was only 20 percent for the reduction to sorbitol.

To attempt to improve the overall cell performance a flowthrough packed-bed reactor with a Raney nickel cathode and a graphite chlp anode was constructed. $(5,7)$ The horizontal bed electrodes were separated by a fritted-glass disk. The electrolyte, 1.6M glucose and $0.4 \mathrm{M} \mathrm{CaBr} 2$, entered at the top of the cell and exited through the bottom. The other operating conditions for the reactor were:

- applied current - 500 mA

- electrolyte flow rate $-100 \mathrm{ml} / \mathrm{min}$

- current efficiencies (at 0.3 Faraday per mole) - sorbitol $80 \%$; gluconic acid $100 \%$

- product ylelds (at 0.3 Faradays per mole) - sorb1tol 100\%; glucontc actd $100 \%$.

A method to separate the products and supporting electrolyte downstream of the electrochemical flow cell was devised. The product mixture was first dried and $\mathrm{CaBr}_{2}$ removed with absolute alcohol. Water dissolved the sorbitol leaving calcium gluconate.

A preliminary econonic analysis of the process showed that the cost of producing $1 \mathrm{lb}(0.45 \mathrm{~kg})$ of calclum gluconate with the simultaneous production of $0.68 \mathrm{lb}(0.31 \mathrm{~kg})$ of sorbitol in a palred synthesis ( $\$ 0.896$ ) was considerably less than the cost of synthesizing the same products in separate electrochemical cells $(\$ 1.20)$. 


\section{REFERENCES}

1. Roberts, R., "Status of the DOE Battery and Electrochemical Technology Program," The MITRE Corporation, Report No. MTR-8026, September 1979.

2. Roberts, R., "Status of the DOE Battery and Electrochemical Technology Program II," The MITRE Corporation, Report No. MTR-80W15, December 1980.

3. Roberts, R., "Status of the DOE Battery and Electrochemical Technology Program III," The MITRE Corporation, Report No. MTR-8IW223, February 1982.

4. Roberts, R., "Status of the DOE Battery and Electrochemical Technology Program IV," The MITRE Corporation, Report No. MTR-82W232, May 1983.

5. "Proceedings of the S1xth DOE Electrochemical Contractor's Review," CONF-840677, June 24-28, 1984.

6. "Project Summarles: S1xth DOE Electrochemical Contractor's Rev1ew," CONF-840677, June 1984.

7. K1noshita, K., Ed1tor, "Annual Report for 1983 Technology Base Research Project for Electrochemlcal Energy Storage," Lawrence Berkeley Laboratory, LBL-17742, May 1984.

8. Shoemaker, P., Editor "Exploratory Technology Development and Test1ng Project - Execut1ve Summary" Annual Report for Calendar 1983, Sandia Net1onal Laboratorfes, June 1984.

9. Chre1tzberg, A.M., "Research, Development, and Demonstration of Advanced Lead-Ac1d Batterles for Ut1lity Load Leveling" Exide Management and Technology Company, Contract No. 31-109-38-4951, Argonne Nattonal Laboratory, Report No. ANL/OEPM-83-6, August 1983.

10. Bowman, D.E., "Annual Report for 1982 on Reaearch, Development, and Demonstration of Lead-Acid Batterles for Electric Vehfcle Propulsion", Globe Battery Division, Johnson Controls, Inc., Contract No. 31-109-38-4205, Argonne Nationa1 Laboratory Report No. ANL/OEPM 83-9, August 1983.

11. Nowak, D., J. Electrochem. Soc. 130, 331 C, (1983).

12. Nowak, D., and $\mathrm{X}$. Tomantschger, J. Electrochem. Soc. $130,331 \mathrm{C}$ (1983). 


\section{REFERENCES}

13. Broglio, E.P., "Annual Report for 1982 on Research, Development, and Denonstration of Nickel-Iron Batteries for Electric Vehicle Propulsion," Eagle-Plcher Industries, Contract No. 31-109-38-6850, Argonne National Laboratory, Report No. ANL/OEPM-83-7, May 1983.

14. West1nghouse Electric Corporation, "Annual Report for 1982 on Research, Development, and Demonstration of Nickel-Iron Batterfes for Electric Vehicle Propulsion," Argonne National Laboratory, ANL Report ANL/OEPM-83-8, May 1983.

15. Pound, B., B. Sundararay, R.P. Singh, and D.D. Macdonald, "Thermodynamic Framework for Estlmating the Efficlencles of Alkaline Batterles," Final Report, Lawrence Berkeley Laboratory Report LBL-16806, October 1983.

16. McKubre, M.C.H., "Temperature Limitation of Primary and Secondary Battery Electrodes," Lawrence Berkeley Laboratory Report, LBL-16141, May 1983.

17. Poa, D.S., J.F. Miller, and N.P. Yao, "The Mechanfsm and Kinetics of Iron Flectrode Dissolution in KOH Electrolytes," Extended Abstracts of Battery Division, The Electrochemistry Soclety, Inc., Fall Meeting, p. 17, October 9-14, 1983.

18. Adler, T.C., F.R. McLarnon, and E.J. Calrns, "Studies of the Zinc Electrode: Effects of Charging Regime and Electrolyte Composition," International Soclety of Electrochemistry, 35th Meet1ng, Extended Abstracts, p. 304, August 5-10, 1984.

19. McBreen, J., and E. Gannon, "The Role of Bismuth Oxide Additives in Zinc Electrodes," Extended Abstracts of Battery Division, The Etectrochemistry Society, Inc., Fall Meeting, p. 13, October 9-14, 1983.

20. McBreen, J., E. Gannon, D-T. Chin and R. Seth1, J. Electrochem. Soc. 130, 1641 (1983).

22. Bhakta, S.D., "Battery Transport Data," Lawrence Berkeley Laboratory Report, LBL-16556, April 1983. 


\section{REFERENCES}

23. Rugger1, R.T. and T.R. Beck, "Development of Mult1component Transport Theory and Transport Data for Membranes in Concentrated Electrolytes" Lawrence Berkeley Laboratory Report, I.BL-16557, July 1983.

24. Madou, M.J. and M.C.H. McKubre, J. Electrochem. Soc. 130, 1056, (1983).

25. Madou, M.J., "A Semlconductor Electro-chemlstry Approach to the Study of 0xide Films on Nicke1, Iron, Zinc, and Cadmium Electrodes" Annual Report SRI International, SRI Project 5703, June 1984.

26. Lee, J, C.C. Christianson, and N.P. Yao, Extended Abstracts of Battery Division, The Electrochemical Soclety, Inc., Washington, D.C., p. 20-21, October 9-14, 1983.

27. Lee, J, K. W. Cho1, C.C. Christianson, and N.P. Yao, Extended Abstracts Electrochemical Soclety Mtg., Detrolt MI, Vol. 82-2, p. 5-6 (1982).

28. Berk, L.B, and C.T. Liu, J. Electrochem. Soc. 131, 952 (1984).

29. Ross, P.N., "Corroston of Carbon in Gas Evolving Electrodes" International Society of Electrochemistry 35th Meeting, Extended Abstracts, p. 48, August 5-10, 1984.

30. Cooper, J.F., "Aluminum-A1r Power Cell Research and Development Progress Report", Lawrence L1vermore Laboratory Report, UCRL-90465 (Preprint) dated Feb. 22, 1984.

31. Cooper, J.F., "Estimate of the Consumer Cost of Aluminum Feed for Electric Vehicles" Lawrence Livermore Laboratory Report, UCRL-90468 (Preprint) dated Feb. 22, 1984.

32. Bellows, R.J., C. Elspass, H. Elnste1n, P. Grlmes, E. Kantner, P. Malechesky and K. Newby, "Zinc-Bromine Batterles for Bulk Energy Storage" 18th Intersoclety Energy Conversion Engineering Conference, IECEC paper no. 839278. August 21-26, 1983 , p. 1696.

33. Bellows, R.J., P. Grimes, H. Elnste1n, E. Kantner, P. Malachesky, and K. Newby, IEEE Transactions on Vehlcular Technology, VT-32, 26 (1983). 
34. (a) Barton, J.L. and J. OM Bockr1s, Proc. Roy. Soc., 268A, 485

(1962). (b) Diggle, J.W., A.R. Despic, and J. O'M.Bockris, J. Electrochem. Soc., 116, 1503 (1969).

35. Landau, U., "Zinc Electrodeposition and Dendrite Growth from Z1nc Halide Electrolytes" Final Report EPRI Em-2393, Case Western Reserve Unfversity, Cleveland, Ohio, May 1982.

36. Hsie, W.C. and J.R. Selman, "Zinc Electrodes in Flowing Acidic Electrolytes" International Soclety of Electrochemistry 35th Meeting, Extended Abstracts, p. 211, August 5-10, 1984.

37. Foos, J.S. and L.M. Rembetsy, "Sulfolane Electrolytes for Secondary Cells", International Soclety of Electrochemistry, 35 th Meeting, Extended Abstracts, p. 237, August 5-10, 1984.

38. Farrington, G.C., B. Scrosat1, D. Frydrych, and J. DeNuzz1o, J. Electrochem. Soc. 131, 7 (1984).

39. Nazr1, G. and R.H. Muller, "Effect of Residual Water in Propylene Carbonate on Films Formed on Lithium," Extended Abstracts of Battery Diviston, The Electrochemical Soclety, Inc., Fall Meeting, Washington, D.C., p. 98, October 9-14, 1983.

40. Hanson, K.J., M. Matlosz, C.W. Toblas, and J. Newman, "Theory of Cyclic Voltammetry for Reactions having Complex Sto1chiometry," Internationa1 Soclety of Electrochem1stry, 35th Meeting, Extended Abstracts, p. 950, August 5-10, 1984.

41. Mark, A.J., I.D. Raistr1ck, and R.A. Hugglns, J. Electrochem. Soc., 130, 776 (1983).

42. Ralstrick, I.D. and R.A. Huggins, "Electrochemical Studies of Lithium Insertion Reactions of Vanadium Oxide Bronzes" Extended Abstracts of Battery Division, The Electrochemical Society, Inc., Fall Meet1ng, Washington, D.C., p. 115, October 9-14, 1983.

43. Barney, D.L., R.K. Steunenberg, A.A. Chilenkas, E.C. Gay, and J.E. Battles, "Lith1um/Iron Sulfide Batteries for Electric-Vehicle Propulsion and Other Applications", Argonne National Laboratory, Report No. ANL 83-62, dated September 1983.

44. Gay, E.C., J.E. Battles, and W.E. M11ler, J. Electrochem. Soc. 130, 1646 , (1983). 


\section{REFERENCES}

45. Chen, D.M. and H.F. Glbbard, J. Electrochem Soc. 130, 1975 (1983).

46. Redey, L. and D.R. Vissers, J. Electrochem Soc. 130, 231 (1983).

47. Maroni, V.A. and Z. Tomczuk, J. Electrochem. Soc. 130, 864 (1983).

48. Preto, S.K., Z. Tomczuk, S. von Wlnbush, and M.F. Roche, J. Electrochem. Soc. 130, 264, (1983).

49. Redey, L. and D.R. Vissers, "Electrochemical Performance of Porous N1ckel Sulfide Electrodes", International Soclety of Electrochenistry, 35th Meeting, Extended Abstracts, p. 78, August 5-10, 1984 .

50. Godsha11, N.A., I.D. Ralstr1ck, and R.A. Hugg1ns, J. Elect rochem. Soc. 131, 543, (1984).

51. Buechele, A.C., L. C. de Jonghe, and D. Hitchcock, J. Electrochem. Soc. 130, 1043 (1983).

52. de Jonghe, L.C., "Degradation of Solld Electrolytes" International Society of Electrochemistry, 35th Meeting, Extended Abstracts, p. 14, August 5-10, 1984.

53. Feldman, L., and L.C. de Jonghe, J. Mat. Sc1., 17, 517 (1982).

54. Wroblowa, H.S., V. Markovac, R.P. Tischer, and G.M. Crosble, "Corrosion of Materials in Sodium Sulfur Cells", International Soclety of Electrochemistry, 35th Meeting, Extended Abstracts, p. 252, August 5-10, 1984.

55. EXXON Enterprises, U.S.-Pat. 4060412 (1977); W.L. Winterbottom, R.P. Tischer, and H.S. Wrobolawa, Patent pending. (as cited in reference 54 ).

56. Wuensch, B.J., L.J. Schioler, and E. Prince "Relation Between Structure and Conductivity in the NASICON Solid Solution System". Proceedings of the Conference on High Temperature Solld 0xide Electrolyes, Vol II-Cation Conductors. Brookhaven Nat1onal Laboratory BNL-51728, p. 55, 0ctober 1983. 
58. Ross, P. and F. Wagner, "The Application of Surface Physics Technlques to the Study of Electrochemical Systems", Adv. In Electrochem, and Electrochem. Eng., C. Toblas and H. Ger1scher eds., J. W1ley and Sons, New York (1984) pp. 69-112.

59. Wagner, F., and P. Ross, J. Electroanal. Chem., 150, 141, (1983).

58. Andricacos, P., and P. Ross, J. Electrochem. Soc., 130, 1340 (1983); 130,1353 (1983); 131, 1531, (1984).

59. Andricacos, P., and P. Ross, J. Electroana1. Chem., 167, 301, (1984).

60. Dees, D.W. and C.W. Toblas, "Development of a Data Acquisition and Control System for the Study of Mass Transfer Phenomena on a Micro-Mosalc Electrode," Electrochemical Society Extended Abstracts, vol 83-1, Extended Abstract 469, May 8-13, 1983.

61. Dees, D.W. and C.W. Toblas, "A Micro-Mosalc Electrode for the Study of Transport Phenomena at Gas Evolving Surfaces," Internationa1 Society of Electrochemistry, 33rd Meeting, Extended Abstracts, p. 456, Sept. 5-10, 1982 .

62. Dees, D.W. and C.W. Toblas, "Experimental Observations of Free Convection Mass Transfer to a Horizontal Surface with a M1cro-Mosa1c Electrode," Electrochemical Society Extended Abstracts, Vo1 84-1, Extended Abstract 394, May 6-11, 1984. 
APPENDIX A

\section{ABBREVIATIONS}

For the reader's convenfence, this appendix lists acronyms and abbreviations that appear in the text. The abbreviations have been subdivided 1nto three categorles, the first covering organizations and programs, the second technical terms, and the third physical units.

\section{Organizations and Programs}

\begin{tabular}{|c|c|}
\hline AMB & Aqueous Mobtle Battery Profect \\
\hline ANL & Argonne National Laboratory \\
\hline BCT & Battery Components Technology (ANL) \\
\hline $\mathrm{BECC}$ & Battery and Electrochemical Contractor's Conference \\
\hline BEST & Battery Energy Storage Test \\
\hline BNL & Brookhaven National Laboratory \\
\hline CWRU & Case Western Reserve UnIversity \\
\hline DOE & Department of Energy \\
\hline EC & office of Energy Congervation (DOE) \\
\hline ECS & Electrochemical Energy Storage Branch (DOE) \\
\hline EDA & Energy Development Assoclates, a Gulf+Western Co. \\
\hline EES & Electrical Energy Systems Program (DOE) \\
\hline EHV & Electric and Hybrid Vehicle Program (DOE) \\
\hline EP & Eagle Plcher \\
\hline EPRI & Electric Power Research Institute \\
\hline ESR & Energy Systems Research (DOE) \\
\hline ETD & Exploratory Technology Development and Test1ng (SNL) \\
\hline ETV-1 & Electrlc Test Vehicle -1 \\
\hline EV & Electric Vehicle \\
\hline FC & Fuel Cel1 \\
\hline FY & Fiscal Year \\
\hline G.E. & Genera1 Electric Co. \\
\hline HNEI & Hawa11 Natural Energy Inotitute \\
\hline IIT & Illinols Institute of Technology \\
\hline JPL & Jet Propulsion Laboratory \\
\hline IANL & Los Alamos National Laboratory \\
\hline LBL & Lawrence Berkeley Laboratory \\
\hline LLNL & Lawrence Livermore National Laboratory \\
\hline NBTL & National Battery Test Laboratory (ANL) \\
\hline PSE\&G & Public Service Gas and Electric \\
\hline $\mathrm{RE}$ & Renewable Energy Program (DOE) \\
\hline $\mathrm{SE}$ & Solar Energy Program (DOE) \\
\hline SNL & Sandia National Laboratories \\
\hline SOHIO & Standard 011 of ohto \\
\hline STOR & Energy Storage Technology Division (DOE) \\
\hline TBR. & Technology Base Research (LBL) \\
\hline TSD & Technology and Systems Development Branch (DOE) \\
\hline TVA & Tennessee Valley Authority \\
\hline
\end{tabular}




\section{Organizations and Programs (continued)}

UAH University of Alabama, Huntsville

UTC United Technologies Corporation

\section{Technical Terms}

\begin{tabular}{|c|c|}
\hline ac & alternating current \\
\hline ASR & Area spectfic resistance \\
\hline BET & Brunauer, Emmett, Teller \\
\hline BOP & Balance of plant \\
\hline CIPR & Current interruption electrode potential relaxation \\
\hline COTAA & Cobalt tetraazaannulene \\
\hline CoTMPP & Cobalt tetrameso-p-methoxy phenyl porphyrin \\
\hline & direct current \\
\hline DoD & Depth of discharge \\
\hline EDAX & Electron dispersive x-ray spectroscopy \\
\hline EHV & Electric hybrid vehicle \\
\hline ESCA & Electron scanning chemical analysis \\
\hline ETV-1 & Electric test vehicle -1 \\
\hline ETX & Electric motor (ac) and transaxle \\
\hline EV & Electric vehicle \\
\hline EVEM & $\begin{array}{l}\text { Electrical vehicle engineering model (Ford } \mathrm{Na} / \mathrm{S} \\
\text { battery test vehicle) }\end{array}$ \\
\hline FC & Fuel cell \\
\hline FeTMPP & Iron tetramethoxy phenyl porphyrin \\
\hline FePC & Iron phthalocyanine \\
\hline FeTPPA & Iron (II)-tetra-3,4-pyr1d1noporphyrazine \\
\hline FeTSPC & Iron tetrasulfonated phthalocyanine \\
\hline FPE & Fluorinated polyethylene \\
\hline FUDS & Federal urban driving cycle \\
\hline $\mathrm{H}_{2} \mathrm{THPP}$ & Tetramethoxyphenyl porphyrin \\
\hline HREELS & High resolution electron energy loss spectra \\
\hline ICE & Internal combustion englne \\
\hline ISOA & Inproved state-of-the-art \\
\hline LEED & Low energy electron diffraction \\
\hline MO & Molecular orbital \\
\hline MTSP & Metalated tetrasulfonated phthalocyanine \\
\hline NMR & Nuclear magnetic resonance \\
\hline PAM & Positive active material \\
\hline PC & Propylene carbonate \\
\hline PI & Power indicator \\
\hline PTFE & Polytetrafluoroethylene (Teflon $\left.{ }^{R}\right)$ \\
\hline PVC & Polyvinylchloride \\
\hline RCCE & Rotating concentric cylinder electrode \\
\hline RHE & Reversible hydrogen electrode \\
\hline RRDE & Rotating ring disc electrode \\
\hline SB & Shawinlgan Black \\
\hline SEM & Scanning electron microscope \\
\hline
\end{tabular}




\section{Technica1 Terms (continued)}

$\begin{array}{ll}\text { SERS } & \text { Surface enhanced Raman spectroscopy } \\ \text { SIM } & \text { Supported 11quid membrane } \\ \text { SOA } & \text { State-of-the-art } \\ \text { TAA } & \text { Tetraazaannuleme } \\ \text { TFEDSA } & \text { Tetrafluoroethane } 1,2 \text { disulfonic ac1d } \\ \text { TFMSA } & \text { TrIfluoromethyl sulfonlc ac1d } \\ \text { TMPP } & \text { Tetramethoxy pheny1 porphyrin } \\ \text { WEBS } & \text { Wind energy battery syotem } \\ \text { XAFS } & \text { X-ray absorption fine structure } \\ & \quad \text { Physical Units }\end{array}$

\begin{tabular}{|c|c|}
\hline A & ampere \\
\hline cc & cubic centimeter \\
\hline Cm & cent1meter \\
\hline Emf & $\begin{array}{l}\text { electromotive force, V } \\
\text { grams }\end{array}$ \\
\hline $\begin{array}{l}\text { g } \\
\text {, hrs }\end{array}$ & hour (s) \\
\hline $\mathrm{Hz}$ & Herz (cycles/sec) \\
\hline kg & k1lograms \\
\hline km & k1lometers \\
\hline $\mathbf{k P a}$ & k1lopascals ( $\left.1.01 \times 10^{2} \mathrm{kPa}=1 \mathrm{~atm}\right)$ \\
\hline $\mathrm{kV}$ & kolovolts \\
\hline $\mathrm{kW}$ & kllowatts \\
\hline kWh & k1lowatt hours \\
\hline 1 & 11 ter \\
\hline m & meter \\
\hline $\mathbf{M}$ & molar \\
\hline ma & milliampere \\
\hline mah & m1111ampere hours \\
\hline $\mathbf{m I}$ & mile \\
\hline ml & mll1111ter \\
\hline m/o & mole percent \\
\hline $\begin{array}{l}\mathrm{mph} \\
\mathrm{mW}\end{array}$ & $\begin{array}{l}\text { m1les per hour } \\
\text { milliwatts }\end{array}$ \\
\hline $\begin{array}{l}\mathrm{mW} \\
\mathrm{MW}\end{array}$ & $\begin{array}{l}\text { milliwatts } \\
\text { megawatts }\end{array}$ \\
\hline Wh & megawatt hours \\
\hline no & nanometer \\
\hline rp田 & revolutions per minute \\
\hline $\begin{array}{l}\text { sp. gr. } \\
\text { v }\end{array}$ & $\begin{array}{l}\text { specific gravity } \\
\text { volts }\end{array}$ \\
\hline $\mathrm{v} / \mathrm{o}$ & volume percent \\
\hline $\mathbf{W}$ & watts \\
\hline $\begin{array}{l}\text { Wh } \\
\text { w/o }\end{array}$ & watt hours \\
\hline$\mu$ & micron \\
\hline$\mu_{\mathbf{g}}$ & microgram \\
\hline
\end{tabular}




.




\section{DISTRIBUTION}

No. of

Copies

OFFSITE

$10 \mathrm{Mr} \cdot \mathrm{J}$. Quinn

U.S. Department of Energy

Forrestal Building, Rm 6A049

1000 Independence Ave., SW

Washington, DC 20585

10 Dr. A. R. Landgrebe

U.S. Department of Energy

Electrochemical Energy Storage

CE-141, MS 5 E-036

Forrestal Building

1000 Independence Ave., SW

Washington, DC 20585

30 DOE Technical Information Center

Dr. J. Birk

Electric Power Research

Institute

3412 Hillview Ave.

P0 $80 \times 10412$

Pato Alto, CA 94303

Mr. J. Brogan

U.S. Department of Energy

Office of Energy Systems

Research

Forrestal Building, Rm 5E-052

1000 Independence Ave., SW

Washington, DC 20585

Mr. P. Brown

U.S. Department of Energy

Forrestal Building

1000 Independence Ave., SW

Washington, DC 20585
No. of

Copies

Dr. E. Cairns

Lawrence Berkeley Laboratory

Energy and Environment Division One Cyclotron Road

Building 90, 3rd Floor

Berkeley, CA 94720

Dr. R. P. Clark

Sandia National Laboratories

P0 $80 \times 5800$

Albuquerque, NM 87185

0r. T. Farrell

U.S. Department of Energy

Electrochemical Energy Storage

Forrestal Building

CE-141, MS S E-036

1000 Independence Ave., SW

Washington, DC 20585

Mr. M. Chiogigio

U.S. Department of Energy

Forrestal Building, Rm 6A049

1000 Independence Ave., SW

Washington, DC 20585

Mr. K. Grothaus

Sandia National Laboratory

Kirtland Air Force Base

P0 Box 5800

Albuquerque, NM 87185

Mr. F. R. Kalhammer

Electric Power Research Institute

3412 Hillview Ave.

P0 Box 10412

Palo Alto, CA 94303 
No. of

Copies

Dr. K. Kinoshita

Lawrence Berkeley Laboratory

Energy and Environment Division

Building 90, 3rd Floor Rm 3026

Berkeley, CA 94720

Mr. R. Kirk

U.S. Department of Energy

Office of Vehicle and

Engineering R\&D

1000 Independence Ave., SW

Washington, DC 20585

Dr. F. McLarnon

Lawrence Berkeley Laboratory

Building 90, Room 3026

Berkeley, CA 94720

Dr. N. J. Magnani

Sandia National Laboratories

PO Box 5800

Albuquerque, NM 87185

Mr. R. Matsumoto

Ceramatec, Inc.

163 west 1700 South

Salt Lake City, UT 84115

Dr. R. Meredith

U.S. Department of Energy

Electrochemical Energy Storage

Forrestal Building

CE-141, MS 5 E-036

1000 Independence Ave., SW

Washington, DC 20585

Dr. E. Brooman

505 King Avenue

Columbus, OH 43201
ONSITE

DOE - Richland Operations

H. E. Ransom

283 Pacific Northwest Laboratory

W. B. Ashton

D. R. Brown

R. M. Fleischman

C. J. Hostick

J. Hurwitch

C. H. Imhoff (271)

Publishing Coordination (2)

Technical Information (5) 